Columbia Law School

Scholarship Archive

2019

\title{
Activist Directors and Agency Costs: What Happens When an Activist Director Goes on the Board?
}

John C. Coffee Jr.

Columbia Law School, jcoffee@law.columbia.edu

Robert J. Jackson Jr.

Joshua Mitts

Columbia Law School, jmitts@law.columbia.edu

Robert Bishop

rbishop17@gsb.columbia.edu

Follow this and additional works at: https://scholarship.law.columbia.edu/faculty_scholarship

Part of the Business Organizations Law Commons, Comparative and Foreign Law Commons, Law and Politics Commons, and the Securities Law Commons

\section{Recommended Citation}

John C. Coffee Jr., Robert J. Jackson Jr., Joshua Mitts \& Robert Bishop, Activist Directors and Agency Costs: What Happens When an Activist Director Goes on the Board?, 104 CORNELL L. REV. 381 (2019).

Available at: https://scholarship.law.columbia.edu/faculty_scholarship/2081

This Article is brought to you for free and open access by the Faculty Publications at Scholarship Archive. It has been accepted for inclusion in Faculty Scholarship by an authorized administrator of Scholarship Archive. For more information, please contact scholarshiparchive@law.columbia.edu. 


\title{
ACTIVIST DIRECTORS AND AGENCY COSTS: WHAT HAPPENS WHEN AN ACTIVIST DIRECTOR GOES ON THE BOARD?
}

\author{
John C. Coffee, Jr., Robert J. Jackson, Jr., \\ Joshua R. Mitts \& Robert E. Bishop $\dagger$
}

We develop and apply a new and more rigorous methodology by which to measure and understand both informed trading and the agency costs of hedge fund activism. We use quanti-tative data to show a systematic relationship between the appointment of a hedge fundnominated director to a corporate board and an increase in informed trading in that corpora-tion's stock (with the relationship being most pronounced when the fund's slate of directors includes a hedge fund em-ployee). This finding is important from two different perspec-tives. First, from a governance perspective, activist hedge funds represent a new and potent force in corporate govern-ance. A robust debate continues as to whether activist funds reduce the agency costs of corporate governance, but this is the first attempt to investigate whether activist hedge funds also impose new agency costs through widened bid-ask spreads and informed trading. Second, although insider trading is almost universally condemned, it has only been studied in individual cases. Using instead a quantitative approach, we develop a tool that enables regulators (civil and criminal) to identify suspicious trading patterns: both to demonstrate such a pattern and to map these new agency costs, we assembled a data set of 475 settlement agreements, between target companies and activist funds relating to the appointment of

$\dagger$ John C. Coffee, Jr. is the Adolf A. Berle Professor of Law at Columbia Law School. Robert J. Jackson, Jr. is a Commissioner of the Securities and Exchange Commission. Joshua R. Mitts is an Associate Professor of Law at Columbia Law School. Robert E. Bishop is a doctoral student at the Yale School of Management. Commissioner Jackson completed his work on this Article prior to joining the Commission. This Article expresses only Commissioner Jackson's views and does not necessarily reflect those of the Commission, the other Commissioners, or the SEC staff. The SEC disclaims responsibility for any private publication or statement of any SEC employee or Commissioner. We are grateful to Lucian Bebchuk, Bernard Black, Emiliano Catan, Albert Choi, Jeffrey Gordon, Colleen Honigsberg, Charles Jones, Darius Palia, Alex Raskolnikov, Eric Talley, and workshop participants at Columbia and NYU for helpful comments and suggestions and to the Columbia Law School for generous financial support. We also wish to thank our two research assistants, Maya Ben Meir and Serdar Inci, both L.L.M. students at Columbia Law School, for their hard work on data coding and legal research. 
fund-nominated directors, from 2000 to 2015, in order to focus on what happens once such a fund-nominated director goes on the board.

\section{Among our principal findings are:}

1. Prevalence of Hedge Fund Employees on Slates. Approximately $70 \%$ of fund-nominated director slates include a hedge fund employee.

2. Increase in Information Leakage. Once a fund-nominated director goes on the board, an abrupt increase in "information leakage" follows, with the result that the target corporation's stock price begins to anticipate future public disclosures. Specifically, we examine some 635,450 Form 8-K's filed by 7,799 publicly traded companies over the period of January 1, 2000 to September 30, 2016, and we construct a control group for each of the corporations subject to an activist intervention. We find that firms appointing an activist nominee or nominees experience a difference-in-differences increase in leakage of twenty-five to twenty-seven percentage points.

3. Hedge Funds Versus Other Activists. We next consider whether post-appointment increases in leakage depend on the identity of the activist investors (i.e., hedge fund versus other activist investors). We find that the leakage effect is clearly driven by hedge fund activists (and no other type of activist).

4. Leakage and Hedge Fund Employees. We investigate whether leakage increases depend on the identity of the director appointed to the target firm's board, distinguishing between hedge fund employees and non-hedge fund employees. We find that the increase in leakage is driven by the appointment of activist fund employees to the corporate board (and not by the appointment of other persons, such as industry professionals).

5. Leakage and Confidentiality Provisions. We consider whether post-settlement increases in leakage are associated with confidentiality provisions restricting information sharing in the settlement agreements. The majority of settlement agreements have no confidentiality provisions, and information leakage is concentrated in these cases.

6. Market Response to Settlement Agreements. We next examine whether the stock market's response to settlement agreements depends on (a) whether a hedge fund employee is on the director slate, and (b) whether the settlement agreement contains or re- 
fers to a confidentiality provision. We find that the five day CAR is more than twice as high $(4.2 \%$ vs. $1.97 \%$ ) for settlements with only non-employee directors and also significantly higher $(2.02 \%$ vs. $0.42 \%$ ) for settlements with an explicit restriction on information sharing.

7. Effect on Bid-Ask Spread. Bid-ask spreads increase by statistically meaningful amounts in our treatment group after an activist director gains access to the boardroom. Bid-ask spreads do not widen for the control groups. Further, we find that the increases in bid-ask spreads are concentrated in those cases in which (i) a hedge fund employee is appointed to the board, or (ii) no confidentiality provision is referenced in the settlement agreement.

8. Options Trading. We find that options trading increases significantly after the appointment of an activist director and in a manner consistent with informed trading. Consistent with earlier research on informed trading, we find that options traders focus on unscheduled Form 8-K filings.

9. Implications. The foregoing pattern is most plausibly explained as the product of informed trading. Material, nonpublic information appears to be incorporated into the market price prior to public disclosure. We reach no conclusions about who is trading or its legality in any individual case. Yet, the widened bid-ask spread strongly suggests that the market expects such trading, and the much more positive market response to director slates without a hedge fund employee (or with a confidentiality provision) suggests that the market suspects that informed trading is closely associated with the appointment of a hedge fund employee to the board.

10. Hypothesis. Our data suggests that the ability to engage in informed trading may serve as a subsidy that inflates the rate of hedge fund activism (producing more engagements than if stronger controls on information sharing were imposed) and may even encourage activists to pursue inefficient engagements. Further, a potential beneficiary of this informed trading may be the "wolf-pack" of activists that follow the lead activist in the engagement. But we stop short of attempting to estimate the size of such impacts.

11. Reforms. We consider and evaluate a variety of possible reforms that are consistent with an energetic 
role for hedge fund activism, but that remove (to various degrees) the subsidy of informed trading.

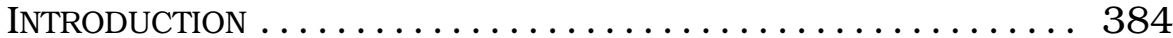

I BACKGROUND AND THEORY................. 393

A. The Private Settlement Process ........... 395

II Agency Costs of Hedge Fund Activism: An

EMPIRICAL ANALYSIS ................... 401

A. Activist Settlements and Director

Appointments .................... 401

B. Confidentiality and Information Sharing

Provisions ......................... 403

C. Private Payments .................. 406

D. Information Leakage: Empirical Study ........ 408

E. Information Leakage after Activist Directors

Gained Boardroom Access ................. 418

F. Options Trading ................... 428

G. Effect on Bid-Ask Spreads .............. 431

III IMPLICATIONS OF FINDINGS AND POSSIBLE REFORMS ... . 434

A. Informed Trading and Hedge Fund Activism ... 434

B. Preempting the Majority's Preference ......... 439

C. Practical Reforms..................... 442

1. Protecting Against Disenfranchisement .... . 442

2. Restricting Informed Trading............ 445

3. Impact and Possible Rebuttals .......... 453

CONCLUSION .............................. 455

\section{INTRODUCTION}

Hedge fund activism has dramatically reshaped corporate governance-arguably revolutionizing it. Almost everyone agrees with this assessment, but they disagree over whether this change is for the better or the worse. An intense and continuing debate has surrounded whether interventions by activist hedge funds enhance shareholder value or only create short-term pressures that compel corporate managers to sacrifice long-term performance. ${ }^{1}$ This Article, however, will not attempt to replough this much-ploughed furrow.

1 Consensus exists only on the common finding that a filing with the SEC (usually of a Schedule 13D) that announces an activist's position in a publicly held company is associated with a positive abnormal stock return. See Alon Brav et al., Hedge Fund Activism, Corporate Governance, and Firm Performance, $63 \mathrm{~J}$. FIN. 1729, 1736-37 (2008). Beyond this point, most empirical conclusions about activism are contested. There is some dispute whether this initial stock price bump fades when no transaction subsequently materializes. However, Bebchuk and others examined the performance of approximately 2,000 activist targets over the five years following these activist's intervention and find no evidence that the 
Instead, our starting point is that, in this new landscape of corporate governance, the activist hedge fund has become the key intermediary. ${ }^{2}$ But, as new agents arise, so do new agency costs. This is definitional. ${ }^{3}$ Unless the interests of the agent and the agent's principal are perfectly aligned, this new agent will find ways to exercise its discretion opportunistically and in its own interests. Thus, this Article's primary goal is to map these new agency costs arising from hedge fund activism. We attempt to do so by using a statistically more rigorous methodology than has previously been applied to either corporate gov-

initial stock price gain fades. See Lucian A. Bebchuk, Alon Brav \& Wei Jiang, The Long-Term Effects of Hedge Fund Activism, 115 ColuM. L. REv. 1085, 1085 (2015). Nonetheless, Cremers and others contend that Bebchuk's findings are largely the product of selection bias and the failure to use a proper control group. They contend that, once control groups are used, a regression to the mean can be seen in the subsequent performance of activist targets. See K.J. Martijn Cremers et al., Hedge Fund Activism and Long-Term Value, https://ssrn.com/abstract=2693231 [https://perma.cc/DRZ4-CFBS] (Dec. 19, 2018). Other scholars have rejected the methodology used in those studies finding that activism results in increases in shareholder value and reported that, under their revised approach, the long-term returns to activism are "insignificantly different from zero." See Ed deHaan, David F. Larcker, and Charles McClure, Long Term Economic Consequences of Hedge Fund Activist Interventions, https://ssrn.com/abstract=3260095 (Oct. 3, 2018). This Article takes no position on this continuing dispute. Many have also raised the claim that short-term pressures compel managers to abandon long-term investments, particularly in research and development, that would have proven profitable, with the result that activism thus produces a negative externality in reduced aggregate investment in research and development. See John C. Coffee, Jr. \& Darius Palia, The Wolf at the Door: The Impact of Hedge Fund Activism on Corporate Governance, 41 J. CORP. L. 545, 545 (2016); Leo E. Strine, Jr., Who Bleeds When the Wolves Bite?: A Flesh-and-Blood Perspective on Hedge Fund Activism and Our Strange Corporate Governance System, 126 YALE L.J. 1870, 1870 (2017). But again, others contend that despite declines in research and development expenditures following activist interventions, target companies nonetheless experience an improvement in innovation efficiency as measured by patent counts and citations. See Alon Brav et al., How Does Hedge Fund Activism Reshape Corporate Innovation?, 130 J. FIN. ECON. 237, 237 (2018).

2 See Ronald J. Gilson \& Jeffrey N. Gordan, The Agency Costs of Agency Capitalism: Activist Investors and the Revaluation of Governance Rights, 113 COLUM. L. REV. 863, 863 (2013).

3 The term "agency costs," first defined by Jensen and Meckling, refers to the costs that arise because of the use by a principal of an agent. These costs include (1) the costs of opportunistic behavior by the agent (such as when the agent places his own self-interest over that of the principal); (2) the costs to the principal of monitoring the agent; and (3) the "bonding" costs incurred by the agent to induce the principal to rely on the agent. See Michael C. Jensen \& William H. Meckling, Theory of the Firm: Managerial Behavior, Agency Costs, and Ownership Structure, 3 J. Fin. ECON. 305, 308 (1976). Others have coined the term "principal costs" to refer to costs imposed on the corporate entity by the principal, such as where there is inter-shareholder conflict. See Zohar Goshen \& Richard Squire, Principal Costs: A New Theory for Corporate Law and Governance, 117 ColuM. L. REV. 767, 767 (2017). This is applicable here also, as the other shareholders may object that decisions by the lead activist were self-interested. 
ernance or white collar crime, which, we hope, will serve as a model for future research in these areas.

Three recent developments (on which this Article will focus) suggest that agency costs are significant and increasing. First, hedge funds are succeeding in placing their nominees on corporate boards, and in 2016, netted a record 131 board seats for their nominees. ${ }^{4}$ Second, the vast majority of these seats were resolved through private agreements (and without a shareholder vote), and the largest and most sophisticated institutional investors have begun to complain that this private settlement process effectively disenfranchises them. ${ }^{5}$ These objectors characteristically differ from the activist fund that initiates the campaign in that they are much larger, more diversified (often highly indexed), and have a substantially longer time horizon. Thus, an important issue is whether the new private settlement process infringes basic norms of shareholder democracy.

Third, in the course of studying this private settlement process, we assembled a data set of 475 private settlement agreements, extending from January 1, 2000 to December 31, 2015. Analyzing these agreements, we discovered a previously unnoticed pattern: when an activist-nominated director or di-

4 In 2016, activists ran some 149 campaigns to secure board representation and netted a record 131 board seats. LAZARD, REVIEW OF SHAREHOLDER ACTIVISM IN 2016, at 1 (2017) [hereinafter LAZARD (2016)]. In 2017, the number of seats won fell to 100 , but the number of campaigns rose to 193 and the amount of capital invested by activists soared to a record $\$ 62$ billion, as activists took on much larger companies. See LAZARD's SHAREHOLDER ADVISORY GROUP, 2017 ACTIVISM YEAR IN REVIEW, at 1, 5 [hereinafter LAZARD (2017)]. Most recently, in the first quarter of 2018, 73 new campaigns were initiated by activists (the highest quarterly level of activity "on record" according to Lazard), and some 65 board seats were won in the first quarter of 2018 (which was "well ahead" of comparable periods in 2016 and 2017). See LAZARD SHAREHOldER ADVISORY GROUP, REVIEW OF SHAREHOldER ACTIVISM - Q1 2018, at 1 [hereinafter LAZARD (2018)]. By all measures, activism is surging.

5 The three largest institutional shareholders are BlackRock, Inc., State Street Global Advisors, and Vanguard, which collectively hold $18.4 \%$ of the stock of companies in the S\&P 500 index. LAZARD (2018), supra note 4, at 8. Each of these three institutions is highly diversified and tends to be a "permanent shareholder," thus differing from activist hedge funds that hold shares for shorter periods. Each has repeatedly objected in letters to the CEOs of major corporations about the short-term vision of activist hedge funds. See infra notes 93-97 and accompanying text. They have also contended that private settlements between the activist fund and corporate management exclude them from any meaningful voice in the selection of the board. For the fullest statement of this view, see Protecting Long-Term Shareholder Interests in Activist Engagements, STATE STREET GLOBAL ADVISORS (Oct. 10, 2016), https://www.ssga.com/investment-topics/environmental-social-governance/2016/Protecting-Long-Term-Shareholder-Interests-in-Activist-Engagements.pdf [https://perma.cc/SAJ7-N3RV]. For a fuller explanation of their critique, see infra notes 95-97 and accompanying text. 
rectors goes on a target corporation's board pursuant to a settlement agreement, a pattern of "information leakage" begins. That is, after such a director is appointed (or even given observer status at board meetings), the stock price of the target corporation begins to anticipate future public disclosures, moving up or down prior to (but in the same direction as that caused by) the eventual public disclosure. Similarly, the bidask spread in the corporation's stock price widens-both in relation to the stock's prior history and to a control group of similar firms. We also find a significant pattern of options trading in advance of new announcements by the target corporation on Form 8-K. The most plausible explanation for this pattern is informed trading. Somehow, material, nonpublic information is being incorporated into the stock's price, and the widened spread reflects the market's anticipation of informed trading (which causes experienced traders to widen their spreads defensively). Whether or not this informed trading is unlawful, it represents an agency cost that the other shareholders bear.

To underscore the importance of both these findings (that private settlement agreements may be preempting shareholder elections and that informed trading seems to increase in the wake of activist interventions), one should understand that, in 2016 , activists won a record number of board seats, but $95 \%$ of these seats were obtained through private settlement negotiations, not proxy contests. ${ }^{6}$

At present, most of the academic literature on hedge fund activism tends to reflect an optimistic view under which activists are seen as desirable agents of change, who intentionally invest in underperforming companies to organize the other shareholders to support their proposals (which usually seek to increase leverage and shareholder payout, trim waste, and/or change senior management). ${ }^{7}$ So viewed, the process may seem a model of shareholder democracy, as the activists make proposals, managements respond, and the balance of the shareholders (who are largely sophisticated institutional inves-

6 LAZARD (2016), supra note 4, at 1 . This $95 \%$ figure is in sharp contrast to the earlier pattern. Two years earlier, in 2014, 34\% of the board seats won by activists were won in actual proxy contests, not private settlements. Id. Thus, the shift towards private settlements is accelerating. In 2017 , this rate fell to $86 \%$ (i.e., 86 of the 100 seats won that year were as the result of private settlements). LAZARD (2017), supra note 4 , at 5 .

7 For this view, see Gilson \& Gordon, supra note 2, at 876 (emphasizing that institutional investors, without the leadership of the activist fund, would remain passive and silent). 
tors) decide the issue. From this perspective, the result is governance by referendum, with a well-informed debate, followed by a vote. All that is new here is the appearance of an entrepreneurial intermediary (the activist hedge fund), who searches for underperforming companies, makes proposals, and lobbies the other shareholders, who hold the balance of power, to act in their mutual self-interest.

But a more skeptical view of activism may be necessary because the process does not actually work this simply. ${ }^{8}$ In reality, there are relatively few shareholder votes on activists' proposals or director nominees. Instead, the activists and management typically settle their disputes through private negotiations, with the activists sometimes receiving private benefits not available to the other shareholders. ${ }^{9}$ Why does management settle rather than fight (and thus let all shareholders decide)? Our answer is that the CEO's job is imperiled, unless he or she settles. ${ }^{10}$ With its human capital locked into the company, senior management of a company "engaged" by activists has every reason to behave in a risk-averse fashion. Additionally, drawn-out proxy fights introduce uncertainty into the company and divert managerial time. For both reasons, the vast majority of the directors placed on the board as the result of activist pressure is appointed through privately negotiated settlements, thus allowing management to avoid the risk of a proxy contest. ${ }^{11}$ Large institutional investors have begun to object vocally to this private settlement process. ${ }^{12}$ Regarding themselves as the company's "permanent shareholders," these institutions assert that de facto power has shifted to short-term activists who often have a distinctly different agenda from theirs.

8 For such a more skeptical view, see Coffee \& Palia, supra note 1, at 562-68.

9 See infra subpart II.A.

10 Lazard's Shareholder Advisory Group reports that, since 2013, annualized CEO turnover at activist targets has averaged 23\% compared to $12 \%$ for nontargets. LAZARD'S SHAREHOLDER ADVISORY GROUP, REVIEW OF SHAREHOLDER ACTIVISM-3Q 2017, at 1 (2017). For the even higher rate of turnover if activist nominees go onto the board, see infra note 47 and accompanying text (reporting study by FTI Consulting showing that the CEO turnover rate rises to $55.1 \%$ over two years if activists place one or more nominees on the board). Further evidence of management's risk aversion lies in the fact that when there actually is a proxy contest, management usually wins. In 2016, Lazard found that activists won in only $38 \%$ of proxy contests. LAZARD (2016), supra note 4 , at 1 . This suggests that management prefers to settle, except in cases where it is highly confident that it can win.

11 See LAZARD (2018), supra note 4, at 1.

12 See infra notes 90-95 and accompanying text. 
Viewed from this perspective, one does not see the simple democracy of the Swiss canton, but instead a process of backroom deal-making reminiscent of a political "machine." The distance between these two perspectives largely turns on whether private settlements may result in different outcomes than shareholder elections do.

These twin concerns-the impact of activist interventions on shareholder democracy and the pervasiveness of informed trading once an activist goes on the board-may seem unrelated, but they are both examples of agency costs. We believe these costs are significant and that they have not yet been seriously examined. Still, we must emphasize at the outset that we do not assert that shareholder activism is fatally flawed, and we believe feasible reforms are easily within reach. Nor do we doubt that rational investors will often want insurgents (including hedge fund activists) to challenge corporate managements. All that we insist is that the loyalty of this new activist agent cannot be automatically assumed.

In this light, two other findings of our study need to be emphasized. First, we find that the stock price pattern from which we detect information leakage and widened bid-ask spreads is particularly pronounced in cases where one of the activist-nominated directors is a hedge fund employee. Put more simply, increases in information leakage occur more often and to a greater degree at companies where a hedge fund employee, rather than a former industry executive, joins the board. This seems plausible because hedge fund employees live in a world of traders (and thus have more opportunities to pass such information, either by way of a quid pro quo exchange or in casual gossip).

Second, we find that there is also a strong relationship between this pattern of information leakage and whether the private settlement agreement seriously attempts to restrict the use of confidential information acquired by the activist-nominated directors. Most agreements are in fact silent on this point, and others seem to tacitly permit information sharing. ${ }^{13}$

These findings lead us to advance three hypotheses. First, the ability to engage in informed trading based on access to material, nonpublic information may provide a subsidy to hedge fund activism. By definition, a subsidy increases the volume or level of the activity subsidized. Here, that means that, on the margin, there may be more activist "engagements" 
and more activist-appointed directors under a system that enables activists to gain access to nonpublic information than under one that more closely restricts such access. Second, providing access to such information may be the social cement that holds together a loose coalition of hedge funds (popularly called a "wolf pack") that supports the lead activist's efforts to compel corporate managements to accept its proposals. Third, activist engagements that propose an inefficient (or at least highly debatable) change in the target's business model may still succeed (or at least capture board seats) because of the desire of these allies of the activist to continue to receive access to material, nonpublic information in return for their support (even if they doubt the wisdom of the lead activist's specific proposal). In short, the corporation risks inefficient changes in its policies or business model when the activist can reward its allies with access to material, nonpublic information. We emphasize that these are hypotheses, not findings, and they will be elaborated and defended in more detail later in this Article.

In fairness, one qualification is necessary at the outset: we do not assert that any specific persons-activist-appointed directors, hedge fund employees, or allies in other hedge fundshave engaged in unlawful insider trading. Inferences of illegality cannot be drawn from our data, standing alone. But it is clear that informed trading has occurred and someone is benefitting. In any event, even if the sharing of material, nonpublic information among investment professionals were not illegal, it would still represent an agency cost for investors and a perverse subsidy for activism that distorts the capital markets.

In this Article, we present empirical evidence of the presence of these agency costs. Using a novel database of 475 settlement agreements between activists and target companies over a fifteen-year period, we systematically study activist settlements and the directors appointed pursuant to those agreements. ${ }^{14}$ Our study differs from other studies in several ways. First, we consider settlement agreements through the end of 2015. The period 2011-2015 saw a substantial increase in the number of settlements with activist investors, and the first

14 We are not the first to study settlement agreements with activist investors, but we are the first to examine closely the market reaction to them and to special characteristics of these arguments. For an earlier study, see Lucian A. Bebchuk et al., Dancing with Activists, https://ssrn.com/abstract=2948869 [https:// perma.cc/P2NR-XNRB] (Last modified Nov. 27, 2017). They focus on the effect of these agreements on the target firm's governance, including board turnover, CEO turnout, payout policy and operational performance. 
public criticisms by diversified institutional investors of activist behavior.

Second, we identify some critical factors in settlement agreements that have not previously been examined (or even noticed). In particular, we compare the five-day cumulative abnormal return ("CAR") to settlements with and without at least one hedge fund employee being added to the board of directors pursuant to the agreement. The average five-day CAR is more than twice as high (4.2\% vs. $1.9 \%)$ for settlements with only non-employee directors, ${ }^{15}$ and this is consistent with our findings (described below) about possible agency costs of having hedge fund employees on the board. Similarly, the average five-day CAR is several times higher ( $2.2 \%$ vs. $0.42 \%)$ for settlements with an explicit rule on information sharing in either the settlement agreement itself or a separate confidentiality agreement. ${ }^{16}$ That activists continue to place hedge fund employees on boards and to resist rules on information sharing against the market's strong preference suggests that some stronger motivation leads activist funds to disregard the market's preference.

To summarize, our main empirical finding is that the appointment of fund-nominated directors causes material information regarding the firm and its operations to become more "leaky"; that is, more of that information makes its way into the company's stock price prior to the public disclosure of that information than in the case of our control group of similarlysituated firms. ${ }^{17}$ The increased leakiness is strongly associated with the appointment of directors who are also employees of the activist investor as opposed to the industry experts typically appointed to the target's board pursuant to an activist settlement. Moreover, leakage is concentrated in settlements without any explicit rule on information sharing in either the settlement agreement itself or a separate confidentiality agreement. We show that bid-ask spreads grow significantly as a result of the appointment of these kinds of activist directors, providing further evidence as to the agency cost inherent in these settlements. ${ }^{18}$

15 See infra notes 62-63 and accompanying text.

16 See infra note 63 and accompanying text.

17 As we show formally in the Theoretical Appendix, the pattern of this leakage follows dynamic behavioral models of criminal wrongdoing: that is, the magnitude of our leakage finding decreases over time, as the probability of detecting trading on leaked information increases.

18 See infra subpart II.G. For a review of the literature describing previous empirical work documenting the benefits associated with hedge fund activism, see 
None of this implies that hedge fund activism is inherently corrupt or misguided. But to the extent that hedge fund activists present themselves as the champion of all the shareholders, there may be a need for greater oversight of this imperfect champion.

A roadmap for this Article is now in order. After this introduction, this Article will examine in Part I the private settlement process surrounding hedge fund "engagements" to show how it differs from a simple democratic model. Part II will then turn to an empirical study of the potential agency costs that are inherent in this new process. Again, this mapping is undertaken not to demonstrate that the shareholder activist must be deterred, but more to suggest where greater controls and transparency are needed. Then, Part III will turn to potential reforms. Here, two issues stand out: (1) Should other shareholders be enabled to participate in, or object to, these private settlements when they substantially change the composition of the board? and (2) How can the agency costs associated with this new activism best be minimized? This Article will then offer some conclusions.

Lucian A. Bebchuk \& Robert J. Jackson Jr., The Law and Economics of Blockholder Disclosure, 2 HARV. BUS. L. REV. 40 (2012). We acknowledge that we are not the first to examine the implications of activist shareholders' access to material nonpublic information. Collin-Dufresne and Fos use an extensive dataset of trades in the target company's stock before the activist's presence is disclosed to consider whether standard measures of adverse selection reflect such trading. See Pierre Collin-Dufresne \& Vyacheslav Fos, Moral Hazard, Informed Trading, and Stock Prices, (THE NATIONAL BUREAU OF ECONOMIC RESEARCH, Working Paper 19619, Nov. 2013), http://www.nber.org/papers/w19619 [https:// perma.cc/6SZV-J9BL]. But that is a very different focus than ours. Federal law requires activists to disclose their stakes to the public within ten days of acquiring greater than 5\% ownership of any class of the target company's stock. As one of us has shown in previous work, activists often use a substantial amount of this ten-day window before disclosing their stake. See Lucian A. Bebchuk et al., PreDisclosure Accumulations by Activist Investors: Evidence and Policy, 39 J. CORP. L. 1, 23 (2013). In the Collin-Dufresne and Fos study, the activist's presence, itself, was the relevant material nonpublic information. Here, we examine the effects of the appointment of activist directors on how fundamental information about a material corporate event makes its way into stock prices after the activist's intervention. We note that in the setting in Collin-Dufresne and Fos, the activist creates the information-that is, the activist's own intervention. By contrast, in our setting, the material corporate event occurs exogenously, and the activist and associated traders profit from information created by (and arguably misappropriated from) the corporate issuer. 


\section{I BACKGROUND AND THEORY}

This Article's focus on the agency costs of hedge fund activism draws upon a new scholarly literature that has distinguished "vertical" agency costs from "horizontal" agency costs. ${ }^{19}$ The classic "vertical" costs were those associated with holding management accountable. But, as scholars studying venture capital have noted, conflicts can also arise among different groups of shareholders who acquired their stock at different times and with different rights. Some shareholders may be able to act opportunistically with respect to the others. Similarly, as the "vertical" agency costs of corporate governance are minimized and management is made more accountable, activists at public corporations may increasingly be able to act opportunistically with respect to two other groups: (1) Other shareholders who (for various reasons) have traditionally been passive and (2) Stakeholders (in particular, creditors and employees). In particular, this Article will assert that a "horizontal" conflict has arisen between activists (who tend to be shortterm shareholders) and indexed institutional investors (who tend to be long-term investors and regard themselves as the company's "permanent shareholders").

As this conflict intensifies, the role of management changes. In the past, managements and boards of directors at public companies have professed that their core responsibility was to balance the interests of all stakeholders. ${ }^{20}$ The larger the company, the more likely that its management would take such a stance. But this balancing (to the extent that it in fact

19 See Robert P. Bartlett, III, Venture Capital, Agency Costs, and the False Dichotomy of the Corporation, 54 UCLA L. REV. 37, 42-45 (2006); Simone M. Sepe, Corporate Agency Problems and Dequity Contracts, 36 J. CoRP. L. 113, 129 (2010). This concept is similar to the idea of "principal costs" developed by Professors Goshen and Squire. See Goshen \& Squire, supra note 3, at 767. For our purposes, differences in nomenclature are not important.

20 Margaret Blair has correctly observed that: "Throughout the middle of the twentieth century through at least the 1970s, most scholars of corporate law, as well as legal and business practitioners, accepted and were comfortable with the idea that boards of directors have to play a balancing role." Margaret M. Blair, Boards of Directors as Mediating Hierarchs, 38 SEATTLE U. L. REV. 297, 315 (2015). Indeed, in 1981, the Business Roundtable published a "Statement on Corporate Responsibility" that insisted that boards were obligated to balance "different constituent interests." See Business RoundTABLe, STATEMENT ON CORPORATE RESPONSIBILITY 75 (1981). See also Harwell Wells, 'Corporation Law is Dead': Heroic Managerialism, the Cold War, and the Puzzle of Corporation Law at the Height of the American Century, 15 U. PA. J. Bus. L. 305, 325-23 (2013) (discussing management's seemingly public role, and responsibilities to various stakeholders, including stockholders, employees, and customers). 
occurred) may have been at least partially a product of high agency costs that sheltered management from shareholder pressure. Once that protection is removed and management loses the discretion it once had, management and the board may come under greater pressure to transfer wealth from creditors and employees to shareholders. Indeed, abundant evidence exists that hedge fund activism has cost creditors significantly and systematically. ${ }^{21}$ In addition, some evidence suggests that shareholder pressure, organized and directed by activist hedge funds, may cause the corporation to act in a more risk-accepting manner and contrary to broadly accepted public policies. ${ }^{22}$ As a result, the tendency to view activists automatically as the "good" guys, and management as the

21 See, e.g., Surendranath Jory, Thanh Ngo \& Jurica Susnjara, The Effect of Shareholder Activism on Bondholders and Stockholders, 66 Q. REV. ECON. \& FIN. 328, 328 (2017) (finding that "activists' demands cause a significant decline in bond returns, and affect long-term bonds the most"); Felix Zhiyu Feng, Qiping Xu \& Heqing Zhu, Caught in the Crossfire: How the Threat of Hedge Fund Activism Affects Creditors, http://papers.ssrn.com/sol3/papers.cfm?abstract_id=271 6929 [https://perma.cc/RRX4-BC7G] (last modified Aug. 20, 2018) (observing that in threatened industries, firms with an ex ante high likelihood of hedge fund activism experience significant losses in bondholder wealth); April Klein \& Emanuel Zur, The Impact of Hedge Fund Activism on the Target Firm's Existing Bondholders, 24 REV. FIN. STUD. 1735, 1735 (2011) (finding that the bond returns from ten days before to one day after the filing of a $13 \mathrm{D}$ are negative $(-3.9 \%)$, that the average abnormal bond returns for one year after the filing date are an additional $4.5 \%$, and that the abnormal stock returns are negatively related to the abnormal bond returns at both the short-term and long-term intervals).

22 To give just two examples, there is evidence that hedge fund activism is (1) negatively affecting board diversity and resulting in less women and minorities serving on boards, and (2) compelling some energy companies to use "dirty" energy and shelve projects to shift to "clean" energy. For the impact on diversity, see Andrew Borek, Zachary Friesner \& Patrick McGurn, The Impact of Shareholder Activism on Board Refreshment Trends at S\&P 1500 Firms, IRRC INST., https:// irrcinstitute.org/wp-content/uploads/2017/08/FINAL-Activism-and-Board-Refreshment-Trends-Report-Aug-2017.pdf [https://perma.cc/N6ZB-PS94] (detailing a study by the ISS and the IRRC). With respect to the impact on the environment, the best example is the campaign led in 2017 by Elliott Management, a prominent hedge fund, to force NRG Energy, Inc., the nation's secondlargest electricity producer, to dispose of its renewable energy assets (basically solar and wind power assets) and return to the use of coal (which was cheaper). See Ed Crooks, Activists Clash Over Direction for NRG Energy, Fin. TIMES (Apr. 4, 2017), https://www.ft.com/content/89417ba2-1d3e-11e7-a454-ab04428977f9 [https://perma.cc/96UK-75SU]; Diane Cardwell \& Alexandra Stevenson, NRG, a Power Company Leaning Green, Faces Activist Challenge, N.Y. TIMES (Apr. 7, 2017), https://www.nytimes.com/2017/04/07/business/dealbook/nrg-elliottmanagement-climate.html [https://perma.cc/A7HK-48YJ]. Eventually, NRG gave in, sold its renewable energy assets, and returned to "dirty" energy. See Russell Gold, NRG to Sell Assets, Slash Costs, Bowing to Activist Pressure, WALL ST. J. (July 12, 2017), https://www.wsj.com/articles/nrg-to-sell-assets-slashcosts-bowing-to-activist-pressure-1499868712 [https://perma.cc/VUD9-2SPD]. 
"bad" guys, when a conflict between them arises, is becoming increasingly dated.

\section{A. The Private Settlement Process}

Democracy relies on voting. But shareholder democracy today turns on private negotiations between activists and management. To illustrate, in 2016, Lazard counted some 149 campaigns initiated by activist shareholders in that year to obtain board representation, and it found that these campaigns had won a record of 131 board seats in $2016 .{ }^{23}$ But $95 \%$ of these seats were obtained through settlement negotiations. ${ }^{24}$ In the relatively few cases that did go to a shareholder vote, management generally won, ${ }^{25}$ suggesting that management settled whenever they saw a serious risk of losing and contested the activists' demands only when management was confident of victory (or could not strike an acceptable deal).

Another study by the State Street Global Advisors ("SSGA"), a major institutional money manager, confirms Lazard's findings. Surveying companies with market capitalizations above $\$ 500$ million (i.e., mid-sized companies and up), SSGA finds that less than $10 \%$ of the board seats conceded in both 2015 and 2016 shifted through a contested proxy election. ${ }^{26}$ Instead, private negotiations dominated, and this trend is increasing. SSGA finds that, in 2014, 34\% of board seats won by activists were obtained through actual proxy elections, which is in marked contrast to the $10 \%$ rate in 2016 and implies that in the recent past, management was more prepared than today to fight a proxy contest. ${ }^{27}$ Put simply, management today seems increasingly risk averse, probably because a defeat in an election contest might discredit it and lead to its eventual ouster. Today, in a negotiated settlement, management (and its public relations professionals) can at least seek to present the outcome in the light most favorable to itself. Skilled at spin control, management would rather settle than fight.

23 LAZARD (2016), supra note 4, at 1 . This 2017 study finds that the number of activist campaigns was down in 2016 (by 17\%) from 2015, but that the number of board seats won (131) was an all-time high, suggesting that activists are becoming more successful. Id.

24 Id.

25 In 2016, Lazard found that activists had a "win rate" in actual proxy contests of only $38 \%$. Id. at 1 .

26 Protecting Long-Term Shareholder Interests in Activist Engagements, supra note 5 , at 1 .

27 Id. 
The activists leading these campaigns are a concentrated group of repeat players, with the table below showing that ten well-known activists won 76 seats-or a clear majority of the 131 seats won by activists in $2016:^{28}$

TABLE A

\begin{tabular}{|c|c|c|c|}
\hline \multirow[b]{2}{*}{ Activist } & \multicolumn{2}{|r|}{2016} & \multirow{2}{*}{$\begin{array}{l}2015 \\
\text { Rank }\end{array}$} \\
\hline & \# of Board Seats Won & Avg. Mkt Cap. of Targets 1 & \\
\hline Starboard Value & 21 & $\$ 10,267$ & 1 \\
\hline Elliott & 12 & 47,026 & 2 \\
\hline Icahn & 9 & 30,105 & 3 \\
\hline Engaged Capital & 8 & 773 & 8 \\
\hline JANA & 7 & 6,314 & 5 \\
\hline Pershing Square & 6 & 19,423 & 19 \\
\hline Glenview & 4 & 2,300 & - \\
\hline Altimeter/PAR & 3 & 17,313 & - \\
\hline Barington & 3 & 1,120 & 13 \\
\hline Lucus (Red Alder) & 3 & 671 & - \\
\hline
\end{tabular}

The majority of the seats filled by activists go to persons resembling traditional independent directors, but Lazard found in 2016 , that $27 \%$ of contested board seats went to employees of the activist fund. ${ }^{29}$ This statistic is important for a number of reasons, including that there appears to be greater information leakage when hedge fund employees are placed on the board (as later discussed).

On balance, the rate of hedge fund activism is increasing. Although the number of activist campaigns fell somewhat in 2016 , the actual number of seats won by activists increased. ${ }^{30}$ The even more significant statistic may be the number of new entrants into this field. Lazard found that 37 activist investors initiated activist campaigns for the first time in 2016. ${ }^{31}$ This increase suggests that these first-time activists saw profits to be made from the activism and have joined the parade.

As earlier noted, activist campaigns generally result in a settlement, which is usually embodied in a settlement agreement. These agreements, which are typically (but not always)

28 LAZARD (2016), supra note 4, at 4. Elliott initiated the most campaigns (13), but won fewer seats than Starboard Value. Id.

29 Id. at 1 . Even this low $27 \%$ rate allows activists who are proposing a slate of candidates (usually between 1 and 4) to include one hedge fund employee. As we later find, approximately $70 \%$ of the slates proposed by activists in our data set include at least one hedge fund employee. See infra Table 1 (finding that 331 activist employees have been appointed to boards and that $69.8 \%$ of the nominee slates in our sample included at least one hedge fund employee).

30 LAZARD (2016), supra note 4, at 1.

31 Id. 
filed with the SEC, have seldom been studied. Professor Lucian Bebchuk and several colleagues recently released one largescale study, 32 but the study goes only until 2011, and much has changed since then. Typically, these settlement agreements address a number of topics, including board composition, standstill provisions, expense reimbursement for the activist, "non-disparagement" provisions, and, possibly, confidentiality provisions (which may or may not restrict the new director or director-nominee from sharing information learned at board meetings with others, including the hedge fund). Such provisions, as next discussed, raise the possibility that the hedge fund activist may receive benefits not available to other shareholders.

A principal conclusion of the Bebchuk study was that these agreements do not address the business operations or policies of the corporation, but rather, focus only on the composition of the board. ${ }^{33}$ Bebchuk and his colleagues conclude that this shows the efficiency of "incomplete contracting." 34 Those more experienced in corporate law would recognize that there is a simpler (if theoretically less elegant) explanation for this focus: directors, as fiduciaries, cannot contract away their discretion. As many cases have held, a contract binding the director, for example, to vote for increased dividends or a share buyback would be unenforceable. ${ }^{35}$ Instead, the settlement agreement must focus on what can be agreed upon: namely, how shareholders will vote for directors and which directors will agree to resign. "Incomplete contracting," at least as an explanation for the structure of settlement agreements, works better in the hothouse of academia than in the real world.

In any event, it is clear that, in a high majority of settlement agreements, new directors are added to the board, usually through an expansion of the board's size. ${ }^{36}$ According to

32 Bebchuk et al., supra note 14.

33 Id. at 4.

34 Id. at 14-17.

35 For early leading cases, see Long Park, Inc. v. Trenton-New Brunswick Theatres Co., 297 N.Y. 174 (1948); McQuade v. Stoneham, 263 N.Y. 323 (1934). New York does permit closely held corporations to opt out of this rule by a charter provision, but there is no exception applicable to publicly held firms. See N.Y. Bus. CORP. LAW § 620(b) (Consol. 2018).

36 The study by Professor Bebchuk and his colleagues finds that new directors are added in $87.4 \%$ of the settlements they surveyed and some incumbent directors leave the board in $40.77 \%$ of these settlements. Bebchuk et al., supra note 14 , at 21 . Thus, the board will typically need to be expanded, which can ordinarily be done by bylaw or board resolution if the corporate charter so authorizes. 
the Bebchuk study, the median number of directors so added is two (although, in at least a few recent cases, majority slates of directors nominated by activists have been elected, giving the activist fund de facto control). ${ }^{37}$ The only other provision that is nearly universal is a standstill provision. ${ }^{38}$

Inevitably, these settlement negotiations provide opportunities for self-dealing by the activist, whose interests can conflict with those of the other shareholders. To give a well-known example, Sotheby's, the art auction house, was engaged in 2014 by Third Point LLC, a leading activist hedge fund, founded by Daniel S. Loeb, one of the highest profile hedge fund activists. Third Point commenced a proxy fight seeking to place three directors on Sotheby's board, but, on the eve of the shareholder meeting (just before the voting outcome would have been announced), Third Point settled in part for a \$10 million payment by Sotheby's as reimbursement of Third Point's expenses. ${ }^{39}$ Because Sotheby's, itself, reported that it had incurred expenses of only \$5.7 million in opposing Third Point's campaign, this payment of $\$ 10$ million to Third Point surprised observers and arguably may have been overly generous. ${ }^{40}$ To be sure, Third Point also negotiated the appointment of the three directors that it had originally sought, but the question remains: was anything traded for this \$10 million payment? No conclusion is expressed here, because the relevant point is only that the interests of Third Point and the other

37 In the Bebchuk study, the median number added to the board was two. Id. at 17 . Still, there is high variation, and the Bebchuk study finds that in 17 cases, the number appointed was four or more. Id. In 2016, well after the 2011 end date of the Bebchuk study, Mantle Ridge, an activist fund, elected a majority slate of directors to the board of CSX Corporation and brought in a new CEO, even though Mantle Ridge held only around a 5\% stake in CSX. See infra note 61 and accompanying text.

38 The Bebchuk study also finds that a "standstill" provision is "almost universal." Bebchuk et al., supra note 14, at 6. It further observes that there can be two types of standstill provisions: (1) a limitation on share ownership by the activist, and (2) a "corporate governance standstill" under which the solicitations of proxies or other actions are halted. Id. at 6 . Although we find that standstill provisions are common, we also find that they do not typically restrict openmarket trading by the activist fund. Often, they are silent on this point, or they may specify a maximum ceiling that the activist cannot cross, but which is above its current ownership level. Generally, the standstill provision focuses more on precluding a proxy contest or further board nominations by the activist or its allies. See infra notes 82-84 and accompanying text.

39 See Alexandra Stevenson, Sotheby's to Reimburse Loeb \$10 Million, N.Y. TiMES (May 7, 2014), https://dealbook.nytimes.com/2014/05/07/sothebys-toreimburse-loeb-10-million/ [https://perma.cc/64WH-VZ5V].

40 Id. 
shareholders could conflict. A tradeoff between management and the activist in such a setting is easy to imagine.

The costs incurred by activists in campaigns for board representation are growing. In the recent and closely contested campaign by the Trian Fund to place Nelson Peltz, its founder, on the Proctor \& Gamble ("P\&G") board, Trian estimated its expected costs at $\$ 25$ million, but acknowledged that they could run higher. ${ }^{41}$ Had P\&G's management recognized that Trian would win this proxy fight, $P \& G$ might have sought a private settlement with Trian that reimbursed some or all of Trian's expenses. This, of course, raises the issue of what P\&G might have asked for in return. ${ }^{42}$

Other conflicts also inevitably exist. When the hedge fund designates a director or directors (some of whom may be hedge fund employees), it will typically remain in close contact with its appointed directors and will likely obtain material, nonpublic information from them. ${ }^{43}$ Potentially, the hedge fund could use that information itself, or it could pass it onto allies. This behavior, depending on its facts, may or may not be unlawful under the federal securities laws or under Delaware law, but regardless, it is an agency cost to the extent it injures the corporation or widens the bid-ask spread. This issue of legality will be delayed until later, but the potential conflict could not be clearer.

41 This estimate was made by Trian in its proxy statement, which conceded that actual costs could prove higher. See Chris Isidore \& David Goldman, Procter $\&$ Gamble declares victory in expensive proxy fight, CNN MONEY (Oct. 10, 2017), http://money.cnn.com.2017/10/10/new/companies/procter-gamble-proxyfight/index.html [https://perma.cc/XX57-PRJ9].

42 There are many things that corporate management might want in return for reimbursement, including: (1) a standstill agreement under which the activist agrees not to buy more stock or launch any proxy fight, and (2) a non-disparagement agreement under which the activist agrees not to criticize management publicly. Both are common provisions in settlement agreements.

43 Delaware law does impose a duty of confidentiality on directors. See, e.g., Shocking Techs., Inc. v. Kosowsky, No. 7164-VCN, 2012 WL 4482838 (Del. Ch. Oct. 1, 2012), vacated, 2015 WL 3455210 (Del. Ch. May 29, 2015) (finding director breached duty of loyalty by providing confidential information to investor); Henshaw v. Am. Cement Corp., 252 A.2d. 125 (Del. Ch. 1969) (allowing inspection of books and records, and limited disclosure so long as it does not breach director's duty of confidentiality). Still, a respected Delaware Vice Chancellor has recently opined that "directors are on solid ground when resisting confidentiality agreements" and probably may share information learned at board meetings with the hedge fund that nominated them and with related colleagues. See J. Travis Laster \& Mark Zeberkiewicz, The Rights and Duties of Blockholder Directors, 70 Bus. L. 33, 48-51 (2014). As later discussed, such sharing may result in broad information leakage. 
A final area where there may be a "horizontal" conflict between the interests of the activist and the other shareholders involves the choice and agenda of the new directors. Diversified institutional shareholders, possibly holding even more stock, might prefer different directors with very different objectives. Recently, BlackRock, Inc., the world's largest investment manager, the Vanguard Group, another of the world's largest investment managers, and SSGA, also a very sizeable investment manager, have all publicly criticized hedge fund activists and the recent settlement process, suggesting that they perceive themselves as having been excluded by these private agreements from the role they deserve as "permanent shareholders," often holding more stock than the activists. ${ }^{44}$ Professor Bebchuk and his colleagues discounted these criticisms, because they found that the nominees selected by activist hedge funds do not receive a lesser vote in subsequent director elections. ${ }^{45}$ One problem with this interpretation, however, is that the Bebchuk study covers results only until 2011, and these large diversified investors began voicing their concerns and criticisms only more recently in 2015 and 2016. ${ }^{46}$ Thus, it remains a very open and debatable issue whether this process is benign.

All that need be concluded at this stage is that activists will usually resolve their differences with the firms they engage through private negotiations that typically change the composition of the board. In the aftermath, the CEO will frequently depart. ${ }^{47}$ Although this process probably focuses on underperforming firms, it has still troubled much larger institutional investors, who consider themselves the target corporation's "permanent" shareholders, but find themselves ignored in these negotiations.

44 See infra notes 93-97 and accompanying text. For SSGA's objections, see infra notes 105-107 and accompanying text.

45 See Bebchuk et al., supra note 14, at 5.

46 See infra notes 93-97 and accompanying text.

47 The Bebchuk study finds that $18.6 \%$ of CEOs depart within a year after the settlement agreement (although only about 3\% of such agreements provide for the CEO's departure). See Bebchuk et al., supra note 14, at 16. A more recent study by FTI Consulting places the departure rates for CEOs after activist nominees are added to the board at $34.1 \%$ and $55.1 \%$ over one and two years, respectively, following these appointments. See Sonali Basak \& Beth Jinks, Activist Investors Double Chance of CEO Exits, Study Shows, BLOOMBERG (Sept. 21, 2016), https:// www.bloomberg.com/news/articles/2016-09-21/activist-investors-doublechance-of-ceo-exits-study-shows [https://perma.cc/7ZBU-CNDM]. 
II

\section{Agency Costs of HedGe Fund Activism: An EMPIRICAL ANALYSIS}

It is possible to hypothesize a variety of ways in which the activist hedge fund can gain private benefits not available to other shareholders or can act contrary to the wishes of the majority of the shareholders because of the leverage it possesses. In the Theoretical Appendix, we set out a formal model underlying many of the arguments we sketch out in this Part. Here, we provide a brief survey of these private benefits, which are enough to raise serious concerns. We begin by describing the data used to establish our empirical claims.

\section{A. Activist Settlements and Director Appointments}

We began by constructing a hand-drawn dataset on activist settlements. First, we pulled all activist events between January 1, 2000 through December 31, 2015 from SharkRepellent. Next, based on SharkRepellent's data, we divided the engagements into those that resulted in the activist receiving board representation and those that did not. ${ }^{48}$ We then examined the securities filings of firms in the former group to identify the nature of the settlement agreement, if any, that led to the appointment of the activist's representative to the board. 49

We then coded the set of activist settlements along several dimensions. ${ }^{50}$ First, we identified the date on which the activist's representative gains access to the boardroom. ${ }^{51}$ We

48 We focus on activist directors appointed through the settlement process because the contracting and compensation dynamic we refer to in Part II above is more reflective of settlement agreements than the uncertain products of the proxy fight process-a process that introduces additional costs and benefits that complicated our analysis. We intend to study activist directors elected through the proxy machinery in future work.

49 We note that our dataset includes cases both where a formal settlement agreement is disclosed and where the target company simply notes in a later securities filing that the board and the activist have reached an agreement to appoint the activist's representative to the board. Both situations reflect an agreement to give the activist representation on the board, and in both cases the activists' representative can be expected to have access to material nonpublic information.

50 We exclude from the dataset any events where the target company lacks data in the Center for Research on Securities Prices (CRSP) database, where an activist has previously gained representation on the target company's board, or where an incumbent director participates in the activist campaign itself.

51 Ordinarily this is simply the exact date on which the new director joins the board-either by way of board appointment or election from the management slate at the annual meeting. We note, however, that in approximately $8 \%$ of the 
then identified the name of each new director and whether the director is an employee of the activist or is an industry expert. 52 We also drew from SharkRepellent information on whether the activist is a hedge fund, individual, investment advisor, corporation, mutual fund, named stockholder group, pension fund, or other institution or stakeholder.

Finally, we examined the settlement agreements themselves, coding for whether the agreements prohibit the activist's initiation of or participation in a formal proxy fight or provide for the reimbursement of the activist's expenses-both the amount and kind of expenses permitted, e.g., filing fees, time, and cost. In light of our focus on information leakage, we also coded whether the agreement contains an express rule restricting information sharing, refers to an information-sharing rule in a separate confidentiality agreement, or refers to a generic policy on information sharing. In addition, we record whether these information-sharing policies apply only to new directors appointed pursuant to the settlement or whether the hedge fund itself is explicitly referenced in the agreement.

Table 1 below provides summary statistics on the characteristics of the 475 settlement agreements in our dataset:

settlements in our dataset the activist instead settles for board "observer" rights, in which the new director gains access to the boardroom before her formal appointment to the board. In these cases, we record the date on which the observer rights become effective. For an example, see Settlement Agreement By and Among Axcelis Technologies and Vertex Capital (Mar. 5, 2015), https:// www.sec.gov/Archives/edgar/data/11132321113232/000110465915017346/a 15-1574_3ex99d2.htm [https://perma.cc/4Z7E-UW3Q] (permitting "each of the [activist's chosen directors to be] appointed as an observer to the Board until the 2015 Annual Meeting . . . [and will] receive copies of all notices and written information furnished to the full Board, reasonably in advance of each meeting to the extent practicable, and [will be] permitted to be present at all meetings of the full Board").

52 We rely on SEC filings, company websites, and Bloomberg profiles to identify each director's background and relationship to the activist. 
Table 1. Summary Statistics: Activist Settlement Agreements. This Table summarizes the characteristics of the 475 settlement agreements that constitute our principal sample.

\begin{tabular}{|l|c|c|}
\hline \multicolumn{1}{|c|}{ Settlement Terms } & $\begin{array}{c}\text { Number of } \\
\text { Observations }\end{array}$ & $\begin{array}{c}\text { \% of Overall } \\
\text { Sample }\end{array}$ \\
\hline $\begin{array}{l}\text { Average Number of Board } \\
\text { Seats Acquired by Activist }\end{array}$ & 1.76 & $(-)$ \\
\hline $\begin{array}{l}\text { Activist Directors Granted } \\
\text { Observer Rights in } \\
\text { Advance of Appointment }\end{array}$ & 37 & $7.8 \%$ \\
\hline $\begin{array}{l}\text { New Director Group } \\
\text { Includes Activist } \\
\text { Employee }\end{array}$ & 331 & $69.8 \%$ \\
\hline $\begin{array}{l}\text { Agreement Includes } \\
\text { Publicly Disclosed } \\
\text { Standstill }\end{array}$ & 263 & $55.4 \%$ \\
\hline $\begin{array}{l}\text { Average Standstill Length } \\
\text { (in Annual Meetings) }\end{array}$ & 1.47 & $(-)$ \\
\hline $\begin{array}{l}\text { Agreement Calls for } \\
\text { Reimbursement of Activist } \\
\text { Expenses }\end{array}$ & 166 & $34.9 \%$ \\
\hline
\end{tabular}

As Table 1 shows, on average each activist engagement results in the appointment of just fewer than two activist representatives to the target company's board, and in nearly $70 \%$ of the agreements at least one of these representatives is an employee of the activist itself.

\section{B. Confidentiality and Information Sharing Provisions}

Of the 475 agreements in our sample, ninety-two (or $19.4 \%$ ) contain an express restriction on information sharing. ${ }^{53}$ In sixty-four of these ninety-two cases, the restriction is set forth in the agreement, and in the remainder it is contained

53 These provisions range from strict to more permissive. For an example of a strict provision, one such agreement (between A.M. Castle \& Co., the target firm, and Raging Capital Group, LLC, an activist investment advisor, and certain individuals in 2015) provided:

Each Member agrees that the Confidential Information shall be kept confidential and that the Members and their Representatives shall not disclose any of the Confidential Information in any manner whatsoever without the specific prior written consent of the Company unless disclosure is required by applicable laws or regulations or pursuant to legal, judicial or regulatory proceedings . . . .

Certain very limited exceptions are then carved out. Settlement Agreement By and Among A. M. Castle \& Co. and Raging Capital Group (Mar. 17, 2015), available at https://www.sec.gov/Archives/edgar/data/18172/0000018172150 00009/exhibit101ragingcapitalset.htm [https://perma.cc/FYT2-G5V4]. 
in a separate confidentiality agreement. ${ }^{54}$ In addition, some seventy-three agreements (or another 16\%) refer to a "policy" on information sharing. ${ }^{55}$ Regardless of whether the information-sharing provision takes the form of a contractual rule or a state policy, we find that some ninety agreements contain an express reference to the activist investor, but these references usually still permit this investor easily to share information with others. ${ }^{56}$

54 Confidentiality agreements are frequently not filed by an issuer with its Form 8 -K or press release announcing the settlement agreement, and thus we did not have full access to them.

55 For example, one such "policy" (in a settlement agreement between the same parties as in supra note 53, but negotiated a year later in 2016) stated:

The $[R C]$ nominee will be governed by the same obligations regarding conflicts of interest, duties, confidentiality, trading and disclosure policies and other governance guidelines as are applicable to all other directors of the Company, all of which policies and guidelines as in effect on the date hereof have been provided by the Company to the $[\mathrm{RC}]$ Group.

Settlement Agreement By and Among A. M. Castle \& Co. and Raging Capital Group (May 27, 2016), available at https://www.sec.gov/Archives /edgar/data/ 18172/000162612916000625/ex10-1.htm. [https://perma.cc/4PPB-3DJB].

Essentially, this "policy" states that the fund-nominated directors are subject to the same rules as the other directors, but it is far from transparent on what those rules are.

56 Here, it is useful to give three examples:

1. In the case of a "Nomination and Standstill Agreement," dated February 25, 2014, by and among CONMED Corporation (the target firm), the Coppersmith Group (the activist investor), and certain nominee directors, Exhibit A to this Agreement provided: "Nothing contained in this Agreement shall prevent the Director from disclosing Confidential Information" to certain persons, defined as "Representatives," which term includes a "principal of Coppersmith." Then, it adds that in the case of disclosure to such a "Representative" of the director: "Any Director Representative shall only be provided Confidential Information by the Director to the extent that they are informed of the confidential nature of the Confidential Information and agree or are otherwise obligated to keep such information confidential and to restrict the use of such Confidential Information in accordance with the terms of this Agreement."

Thus, the director can share with the company's advisors and its activist sponsor, but the director is required to observe confidentiality (which may allow the director to inform still others if these persons in turn promise to observe confidentiality). See Nomination and Standstill Agreement (Feb. 25, 2014), available at https://www.sec.gov/Archives/edgar/data/816956/000089183614000036/ex_ 10-1.htm [https://perma.cc/CS9L-2MBZ].

2. In the case of a "Form of Confidentiality Agreement" attached to a "Director Appointment Agreement," dated November 1, 2014, by and among Epiq Systems, Inc. (the target), and St. Denis J. Villere \& Company, L.L.C., (the activist investor), and certain director nominees, the Confidentiality Agreement permitted the director to disclose Confidential Information to the director's "attorneys, advisors, directors, members, officials, and employees" who were collectively defined as its "Representatives." Par- 
Even after recognizing that many of these provisions are equivocal to weak, the fact still stands out that, in the remaining $64 \%$ of the 475 agreements in our sample, nothing is said in publicly available documents about confidentiality or information sharing. As noted earlier, 57 the market's response to an agreement without any provision on information sharing is modest and dwarfed by its more positive reaction to the presence of such a provision. Although multiple explanations are possible for this disparity, ${ }^{58}$ it at least suggests that it is important to many activists that they be able to share broadly the

agraph 2 of this Confidentiality Agreement required the Director Representatives to "not disclose any of the Confidential Information in any manner whatsoever without the prior written consent of the Company."

See Director Appointment Agreement (Nov. 1, 2014), available at https://www. sec.gov/Archives/edgar/data/1027207/0001 19312514395568/d815407dex 994.htm [https://perma.cc/3N37-EJME]. Once again, the employees, directors, members, and officials of the activist investor can receive full access to what the nominee learns at board meetings (but are subject to a confidentiality obligation).

3. Another variant on this general format was used by the Barington Group (the activist investor) in an "Agreement" it entered into with Lancaster Colony Corporation (the target) on October 9, 2007. It provides that: "The members of the Barington Group (each, a "Recipient") each acknowledge the confidential and proprietary nature of the Confidential Information (as defined below) and agree that the Confidential Information (a) will be kept confidential by Recipient and Recipient's Representatives and (b) will not be disclosed by Recipient (except to other Recipients and their Affiliates and Associates and such person's Representatives to the extent contemplated by this Agreement) or by Recipient's Representatives (as defined below) to any person except with the specific prior written consent of the Company or except as expressly otherwise permitted by this Agreement."

See Agreement by and Among Lancaster Colony Corp. and the Barington Group (Oct. 9, 2007), available at https://www.sec.gov/Archives/edgar/data/57515/ 000095015207007990/128268aexv99w2.htm [https://perma.cc/JM2R-EABN].

In all these cases, the agreement specifically permits the activist investor (here, as a "Recipient") to obtain Confidential Information and share it with its "Representatives" (which term includes its "advisors" and employees). Thus, this scope can include a large number of persons, all learning potentially marketmoving information.

57 See supra note 16 and accompanying text (noting that the five-day difference in CARs is $2.2 \%$ versus $0.42 \%$ - or more than five times).

58 This disparity could plausibly relate to the identity of the hedge fund. If some activist funds were disfavored by the market (for any of a number of possible reasons) and these funds would not tolerate a confidentiality provision, then the disparity might relate less to the issue of confidentiality than to the identity of the fund. However, because $64 \%$ of the settlement agreements in our data sample do not contain any information-sharing provision, it seems unlikely that the disparity is attributable to the "bad" reputation of some funds. It is possible, however, that some activist funds with a "good" reputation do characteristically agree to a confidentiality restriction, and that the market is responding more to their identity than to the provision. 
information they obtain from their director nominees. Later, we will suggest why activist funds may feel this need. ${ }^{59}$

\section{Private Payments}

It is not uncommon for a corporation "engaged" by an activist hedge fund to agree to reimburse the fund for the expenses that it allegedly incurred in connection with the engagement. These expenses might include SEC filing fees, legal expenses, or the costs of an actual proxy campaign (if one was conducted or if a draft proxy statement was prepared). Here, the Sotheby's campaign stands out with its \$10 million payment to Third Point.

How typical is such a large payment? The Bebchuk study includes no findings on this issue. In our dataset of 475 settlement agreements, we find that 166 (35\%) have an expenses reimbursement provision of some sort. We are able to identify a definite amount of expense reimbursement in 148 agreements. The mean and median amounts of expense reimbursement are $\$ 328,753$ and $\$ 100,000$, respectively. Out of these 148 settlement agreements, forty-one $(27.7 \%)$ provide for a reimbursement in the amount of $\$ 250,000$ or more, nineteen $(12.8 \%)$ provide for $\$ 500,000$ or more, and seven $(4.7 \%)$ have an amount of $\$ 1,000,000$ or more.

These data suggest that payments of the same order of magnitude as that paid by Sotheby's to Third Point are few. Although reimbursement is not uncommon, the amounts so paid are usually modest. Because significant and legitimate legal expenses could be incurred by the activist in conducting an engagement, the limited reimbursement that hedge funds report suggests that activists may be constrained by the fear of reputational damage if they disclosed a substantial payment. Alternatively, the activist may want to proclaim that it expects to make such a large profit on its engagement that it does not need to be concerned with penny-ante matters, such as expense reimbursement. Conceivably, some activists do receive a sizable payment, but fail to report it on the ground that it is not financially material. Still, this seems unlikely to us for a variety of reasons. ${ }^{60}$

What does the corporation gain for its payment? Some have suggested that the corporation typically gains a "non-

59 See infra notes 97-103 and accompanying text.

60 One reason is that management of the target would also need to make a disclosure about the settlement agreement, and the possibility that both would agree not to disclose the payment seems small in our judgment. 
disparagement" provision in the settlement agreement. These provisions, which are very common in settlement agreements, bar the activist from publicly criticizing the corporation and its management for the duration of the agreement. In effect, the activist, as the champion of the shareholders, is silenced.

Other forms of payments are also possible. In 2017, Mantle Ridge Partners, LP, a newcomer to hedge fund activism, conducted an extraordinarily successful engagement with CSX Corp. Although holding less than 5\% of CSX's stock, Mantle Ridge was able to secure the appointment of four of its nominees to the CSX board, including a new CEO, E. Hunter Harrison, who brought with him a new strategic plan for CSX. Effectively, Mantle Ridge and its new CEO engineered a palace coup d'etat at CSX. Then, Mantle Ridge asked the CSX shareholders to approve the CEO's pay package in an advisory vote at CSX's annual shareholder meeting. This package included an \$84 million reimbursement to Mantle Ridge of the compensation and benefits forfeited by Harrison when he resigned as the CEO of Canadian Pacific to take the position at CSX. ${ }^{61}$ Although the transaction produced a major stock price jump in CSX's stock, others have noted the shareholders had little choice, as Harrison had indicated that he would resign if the reimbursement was not ratified by CSX's shareholders. ${ }^{62} \mathrm{Be}-$ cause Harrison's resignation might have caused a decline in the stock price that erased the earlier gain, CSX's shareholders were effectively faced with Hobson's choice.

Cases such as CSX show both that shareholders may be pressured to ratify steps taken by their activist champion and

61 For a description of this contest, see Shawn Tully, CSX CEO Hunter Harrison's Pay is No Great Train Robbery, FoRTUNE (Mar. 24, 2017), http://fortune. com/2017/03/24/csx-hunter-harrison-pay/ [https://perma.cc/4D86-M98V]. The payment went to Mantle Ridge, as it had earlier reimbursed Harrison. CSX's shareholders did vote by a wide margin to approve this payment in an advisory vote; thereafter, the CSX board made the legally binding decision to approve the payment. See Michael Flaherty, CSX Shareholders Approve \$84 million Reimbursement to Mantle Ridge, REUTERS (June 5, 2017), https://www.reuters.com/ article/us-csx-harrison/csx-shareholders-approve-84-million-reimbursementto-mantle-ridge-idUSKBN18W1Y6 [https://perma.cc/TR46-3L7J]. Harrison died in December 2017, presenting issues about this ratification that are beyond the scope of this Article.

62 In a review of the transaction, Cleary Gottlieb Steen \& Hamilton LLP observed that "a reasonable argument could be made that the shareholder vote is ... a veneer to shield the board from a tough call." See Ethan A. Klingsberg \& Arthur $\mathrm{H}$. Kohn, Balancing Concessions to Activists Against Responsiveness to the Broader Shareholder Base, HARV. L. SCH. F. ON CORP. GOVERNANCE \& FIN. REG. (Apr. 4, 2017), https://corpgov.law.harvard.edu/2017/04/04/balancing-concessionsto-activists-against-responsiveness-to-the-broader-shareholder-base/ [https:// perma.cc/7PGC-CKGE]. 
that shareholders can earn extraordinary stock gains from activism. Obviously, the goal should be to reduce agency costs without eliminating the shareholder gains.

\section{Information Leakage: Empirical Study}

In this Part, we present an empirical study, which finds that the appointment of an activist nominee or nominees to a corporate board is followed by a short-term increase in information leakage into the target's stock price. That is, prior to the targeted corporation's public disclosure of material information (positive or negative) in the period after an activist nominee is appointed to the board (or granted "observer" status at board meetings), its stock price drifts in the direction that the later corporate disclosure produces. The market reacts to new developments before they are publicly announced, probably because informed trading by those with access to material, nonpublic information is decoded by other traders to imply a likely gain or loss.

To motivate our empirical study of leakage, we first calculate CARs to announcements of settlement agreements. In our entire sample of settlement agreements, we find that the average five-day announcement CAR is $2.64 \%$. But this average conceals substantial heterogeneity. When we examine settlements without any hedge fund employee appointed to the board, we find that the five-day CAR is $4.21 \%$, compared to $1.95 \%$ for settlements with an employee-nominee appointed to the board. This suggests that the market is skeptical of hedge fund employees as directors. Similarly, when we examine settlements with an express rule on information sharing or a rule in a separate confidentiality agreement, we find that the fiveday CAR is $2.25 \%$, compared to $0.42 \%$ for those settlements that contain neither of those restrictions on information sharing. ${ }^{63}$

This presents a puzzle. Why do activist funds continue to appoint their employees to the board and avoid express confidentiality provisions in settlement agreements, despite the market's clear contrary preferences? Activists may believe that the advantages of having an activist on the board and skipping any confidentiality provision in the settlement agreement outweigh the costs of bucking the market's preferences. Those

63 As noted at supra notes 53-57 and accompanying text, 19.4\% of our data sample has a contractual provision that restricted information sharing and another $16 \%$ refers to a "policy" on information sharing. Thus, slightly over $64 \%$ are silent on this issue and seem to experience a much smaller CAR. 
more skeptical of activism suspect that information sharing by the lead activist with its allies may be an important means by which the lead activist can hold together its loose coalition of allies (or wolf pack) and thus maintain its leverage over the target company. ${ }^{64}$ Another possibility is that activist funds appoint employees and disdain confidentiality provisions chiefly when the activists already possess sufficient leverage that target managements dare not resist them for fear that they will incur a proxy contest that they are unlikely to win. ${ }^{65}$ No conclusion or preferred theory is here expressed.

In any event, we next examine how information leakage correlates with these two variables (i.e., an employee nominee and the absence of a confidentiality provision). We construct a dataset that enables us to evaluate the incorporation of information into public-company stock prices. In general, federal law requires many material events to be disclosed on Form 8-K, which generally must be filed within four business days after the occurrence of the event. Thus, Form 8-K filings are typically not scheduled well in advance of their filing and often respond to unexpected developments. We begin with 635,490 Form 8 -Ks filed by 7,799 publicly traded companies over the period of January 1, 2000 to September 30, 2016.

For each Form 8-K filing, we seek to examine the pace at which the information in the filing makes its way into the company's stock price. To do so, we derive a "leakage" measure for a given firm (which we denote as firm " $i$ ") filing a form 8-K on a given date (which we denote as date " $t$ "), which we denote $l e a k_{i, t}$, and is equivalent to a standard measure used in the finance literature known as the "Weighted Price Contribution."66 We calculate this measure as follows:

$$
\text { leak }_{i, t}=\frac{r_{t-5, t-1}^{i}}{r_{t-5, t_{0}}^{i}}
$$

Put simply, the leakage measure is a fraction: the numerator is the percentage change ${ }^{67}$ in the closing stock price of the firm filing the Form 8-K from (a) five days before the event to (b) the day before the event, and the denominator is the percentage

\footnotetext{
64 We discuss this possibility later in infra notes 86-90 and accompanying text.

65 In these cases, the market may already expect an activist victory, so the stock market response to the use of a hedge fund employee may be more muted.

66 Michael J. Barclay \& Terrence Hendershott, Price Discovery and Trading After Hours, 16 REV. FIN. STUD., 1041, 1055, 1058 (2003).

67 These are actually the natural $\log$ of $1+$ the percentage change, i.e., the continuously compounded return over that time.
} 
change in the closing stock price of the firm filing the Form 8-K from (a) five days before the event to (b) the day of the event.

To take a simple example, suppose that the firm's stock price was $\$ 10$ at the close of business five days before the event, $\$ 11$ the day before the event, and $\$ 12$ on the day of the event. The numerator of the ratio is approximately 10\%:68 $\$ 10$ (the price five days before) to $\$ 11$ (the price one day before) is an increase of $10 \%$. The denominator of the ratio is approximately 20\%: \$10 (the price five days before) to $\$ 12$ (the price on the day of the event) is an increase of $20 \%$. The leakage is 50\%, which is obtained by calculating $10 \% / 20 \%$. On average, then, higher levels of leakage indicate that information reflected in the Form 8-K made its way into stock prices in the day before the actual disclosure of that information on Form 8-K.69

The key idea is that this ratio increases as more information makes its way into the stock price prior to the announcement date. However, working with this ratio poses certain challenges as an empirical matter. Theoretically, this ratio should remain bounded between zero and one-e.g., if the stock price goes up by $\$ 2$ from five days before to the day of the disclosure (inclusive), it should not go up by $\$ 3$ from five days before disclosure to the day before the disclosure and fall by $\$ 1$ on the day of disclosure. But in practice, this often happenssimply because markets are not perfectly efficient and trading is noisy. Once we recognize that prices can move for random reasons, it is possible that the denominator may be very close to zero while the numerator is not, causing the ratio to "blow up" dramatically. This poses nontrivial challenges for statistical inference. ${ }^{70}$

68 We use the term "approximately" because of the continuously compounding return.

69 We note that information disclosed on Form 8-K is occasionally previously disclosed to the public in the form of press releases or other public announcements. To address that possibility we search the text of each Form 8-K for phrases related to the issuance of a press release and control for the presence of that phrase in our leakage analysis.

70 Technically, suppose that both $r_{t-5, t-1}^{i}=\alpha_{t-5, t-1}+\epsilon_{t-5, t-1}$ and $r_{t-5, t_{0}}^{i}=\alpha_{t-5, t_{0}}+\epsilon_{t-5, t_{0}}$ where $\epsilon_{t-5, t-1}$ and $\epsilon_{t-5, t_{0}}$ are zero-mean i.i.d. normally distributed random variables. Even if it is the case that $\frac{\alpha_{t-5, t-1}}{\alpha_{t-5, t_{0}}}<1$, it does not follow that $E\left[\frac{r_{t-5, t-1}^{i}}{r_{t-5, t_{0}}^{i}}\right]=\frac{\alpha_{t-5, t-1}}{\alpha_{t-5, t_{0}}}<1$. The ratio of the noise terms $\frac{\epsilon_{t-5, t-1}}{\epsilon_{t-5, t_{0}}}$ is the ratio of two zero-mean normally random variables. This term is Cauchy distributed for which both the first and second moment are not defined. 
There are two ways to address this problem. The standard approach in the finance literature is to multiply this ratio by a weight that is proportional to the absolute value of the denominator. This is the approach taken by Michael Barclay and Terrence Hendershott when deriving the "Weighted Price Contribution," which they use to measure how much stock prices move during different times of the day. ${ }^{71}$ This ensures that observations which have a denominator very close to zero receive a weight very close to zero. We adopt this approach for our primary results, weighting OLS regressions by the absolute value of the denominator.

An alternative approach is to remove filings with "negative" leakage (i.e., where the numerator and denominator of the ratio had different signs), as the ratio is not meaningful in that case, and to remove filings with leakage greater than 1 , which implies a market "overreaction" to the news, while adjusting the coefficient estimates and standard errors for the truncation. ${ }^{72}$ As we show below, our results are generally consistent, both in sign and statistical significance, across these two specifications.

We code as "treatment" filings Form 8-Ks filed by firms that entered into activist settlement agreements and code as "post" filings Form 8-Ks filed after the date that the new director gained access to material nonpublic information, either by joining the board or obtaining observer rights to its deliberations. ${ }^{73}$ This results in essentially 475 different treatments occurring between 2000 and 2016. This gives us comfort that, from the perspective of causal identification, the effect we measure is unlikely to be driven by an unobservable time trend over a single period of time.

Another challenge with making causal inferences as to the effect of appointing activist directors on information leakage is constructing an appropriate "control group." We consider multiple approaches to show that our results are not driven by the choice of a single kind of control group. Our primary estima-

71 The formula for the weight is simple: $w_{i}=\frac{\left|r_{t-5, t_{0}}^{i}\right|}{\sum\left|r_{t-5, t_{0}}^{i}\right|}$ which is exactly what Barclay \& Hendershott utilize in the Weighted Price Contribution. See Barclay \& Hendershott, supra note 66, at 1055.

72 We estimate the truncated re gression model via maximum likelihood as described in J. SCOTT LONG, REGRESSION MODELS FOR CATEGORICAL AND LIMITED DEPENDENT VARIABLES 192 (1997).

73 To reduce the likelihood that the results are driven by differences in leakage far away in time from the date on which the director first gains access to the boardroom, we limit the sample window to an even shorter period before and after the new director gains access to material nonpublic information. 
tions use a "same-industry" control group: we collect, for each settlement agreement, all the Form 8-K filings by other public companies with the same 4-digit SIC industry code as the target firm. For each settlement, there is a treatment firm and a group of control firms which are assigned the same "access to material nonpublic information" date. As we explain below, we further apply propensity-score matching to ensure that we are comparing pre to post differences in leakage between the treatment firms and groups of control firms that are as similar as possible.

For several reasons, we considered it important to verify that the disclosure behavior was similar between our treatment and control groups. In other words, did companies that were the target of a hedge fund engagement file more (or less) Form 8-Ks than those in the treatment group. We find disclosure behavior to be remarkably similar between the two groups. Figure 2 shows a "kernel density plot" for the years between 2000 and 2015. ${ }^{74}$ The close congruence it reveals between the control and treatment groups suggests that the disclosure behavior of public firms does not change because of the appointment of an activist director; both seem to file Form 8-Ks with the same frequency. 
Summary STATISTICS: KeRnel Density Plot OF FoRM 8-K FilingS OvER TIME. The plot below illustrates the volume of Form 8-K filings over time in both our treatment and control groups; as shown below, the incidence of Form 8-Ks in each group over time is statistically indistinguishable.

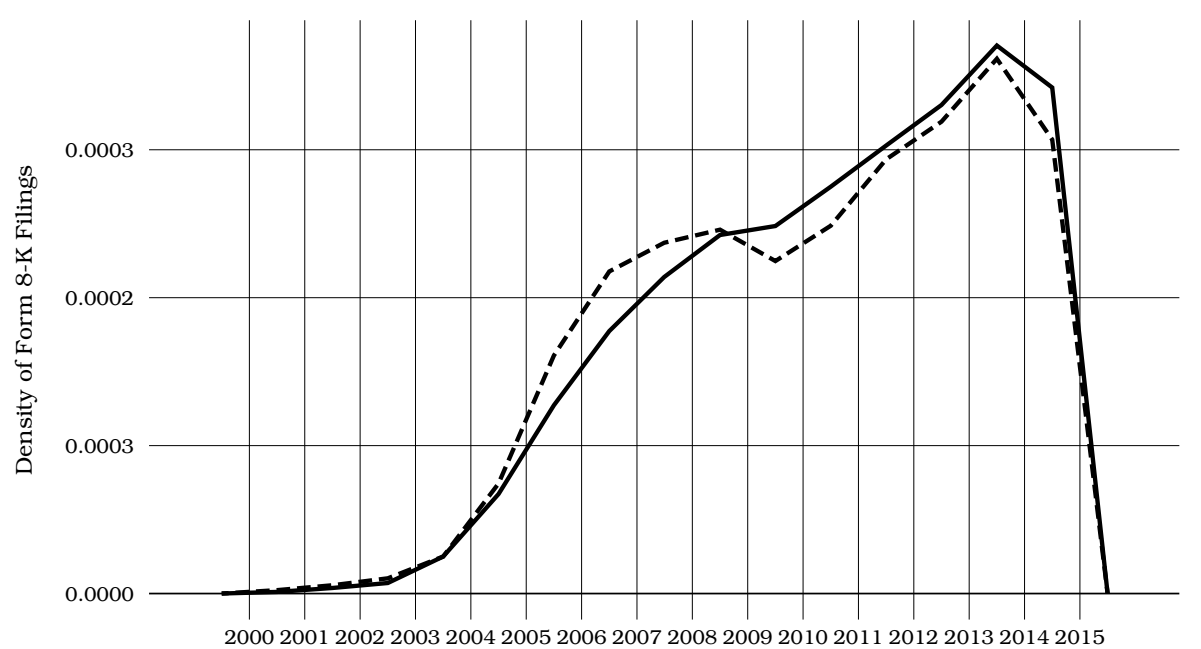

Date Filed

— Control Group - - - - Treatment Group

We derive several additional variables for each firm which could plausibly affect information leakage: its market capitalization (number of shares times price), the Amihud illiquidity measure, ${ }^{75}$ and the idiosyncratic volatility of the firm's stock. ${ }^{76}$ Each of these are calculated over the month preceding each Form 8-K filing.

We also calculate the log of the firm's book-to-market ratio, using its most recent Compustat annual report. We compute the length of the Form 8-K filing as well as whether it refers to a "press release," which might indicate that the filing does not necessarily contain new, public information. Finally, we extract the item numbers-that is, legally specified categories of

75 The Amihud illiquidity measure is the average of the daily ratio of the absolute stock return for that day to the trading volume of that day, as described in Yakov Amihud, Illiquidity and Stock Returns: Cross-Section and Time-Series Effects, 5 J. FIN. MKTS. 31 (2000). For computational simplicity, we depart slightly from the original Amihud paper by using number of shares in the denominator, rather than dollar volume; the two are virtually indistinguishable in daily trading data.

76 Idiosyncratic volatility is the standard deviation of what remains after subtracting the predictions of asset pricing model from stock returns. 
information-from each Form 8-K filing. ${ }^{77}$ We merge the leakage data with these additional variables, along with the "treatment characteristics" coding from the activist settlement agreements, to arrive at the final dataset used in the analysis described below.

Table 2 presents summary statistics from this dataset, including the number of Form 8-K filings, as well as statistics such as the mean, standard deviation, median, and various percentiles for each Form 8-K in the dataset. Variables that correspond to a firm-like the Amihud illiquidity measure or idiosyncratic volatility-reflect the firm filing the Form $8-\mathrm{K}$ and are "linked" to the Form 8-K filed by that firm because these could potentially explain variation in leakage.

77 Public companies today are required to file a Form 8-K for a wide range of corporate events. In securities law parlance, the various events that are subject to disclosure on Form 8-K are referred to as "items." For example, Item 1.03 on Form 8-K requires disclosure of whether the company has entered bankruptcy or receivership, Item 2.01 requires disclosure of the completion of the acquisition or sale of corporate assets, and so on. 
TABle 2. Summary Statistics: Estimation Dataset.

\begin{tabular}{|c|c|c|c|c|c|c|c|c|}
\hline Variable & $\begin{array}{l}\text { Number } \\
\text { of 8-K } \\
\text { Filings }\end{array}$ & Mean & $\begin{array}{l}\text { Standard } \\
\text { Deviation }\end{array}$ & Min. & $\begin{array}{c}25^{\text {th }} \\
\text { Percentile }\end{array}$ & Median & $\begin{array}{c}75^{\text {th }} \\
\text { Percentile }\end{array}$ & Max. \\
\hline $\begin{array}{c}\text { Leakage } \\
\text { Denominator } \\
\text { (\% change } 5 \\
\text { days before } \\
\text { to event day) }\end{array}$ & 575,196 & -0.003 & 0.129 & -2.695 & -0.054 & 0.004 & 0.049 & 3.545 \\
\hline $\begin{array}{l}\text { Leakage } \\
\text { Numerator } \\
\text { (\% change } 5 \\
\text { days before } \\
\text { to } 1 \text { day } \\
\text { before) }\end{array}$ & 575,196 & -0.002 & 0.087 & -2.678 & -0.029 & 0.001 & 0.027 & 3.449 \\
\hline $\begin{array}{l}\text { Leakage } \\
\text { Measure }\end{array}$ & 575,196 & 0.584 & 0.265 & 0.0001 & 0.380 & 0.621 & 0.807 & 1.000 \\
\hline $\begin{array}{l}\text { Treatment } \\
\text { Dummy } \\
\text { (=1 for } 8-K s \\
\text { by targets) }\end{array}$ & 575,196 & 0.022 & 0.147 & 0 & 0 & 0 & 0 & 1 \\
\hline $\begin{array}{c}\text { "Post" } \\
\text { Dummy } \\
\text { (=1 for 8-Ks } \\
\text { filed after } \\
\text { settlement } \\
\text { agreement) }\end{array}$ & 575,196 & 0.462 & 0.499 & 0 & 0 & 0 & 1 & 1 \\
\hline $\begin{array}{l}\text { Hedge Fund } \\
\text { Dummy }\end{array}$ & 12,681 & 0.811 & 0.391 & 0 & 1 & 1 & 1 & 1 \\
\hline $\begin{array}{l}\text { Hedge Fund } \\
\text { Employee } \\
\text { Dummy }\end{array}$ & 12,681 & 0.700 & 0.458 & 0 & 0 & 1 & 1 & 1 \\
\hline $\begin{array}{l}\text { Amihud } \\
\text { (2002) } \\
\text { Illiquidity }\end{array}$ & 500,756 & 4.933 & 8.419 & 0.000 & 1.269 & 2.379 & 5.006 & 782.695 \\
\hline $\begin{array}{l}\text { Idiosyncratic } \\
\text { Volatility }\end{array}$ & 500,659 & 0.030 & 0.026 & 0.000 & 0.015 & 0.023 & 0.036 & 1.393 \\
\hline $\begin{array}{c}\text { Market } \\
\text { Capitalization }\end{array}$ & 500,757 & $5,770,181$ & $23,888,702$ & 633.566 & 157,635 & 591,091 & $2,159,389$ & $735,734,809$ \\
\hline $\begin{array}{l}\text { Log Book to } \\
\text { Market Ratio }\end{array}$ & 476,990 & -4.883 & 1.739 & -12.902 & -5.946 & -4.846 & -3.803 & 16.001 \\
\hline $\begin{array}{c}\text { Days } \\
\text { Between } \\
\text { Activist } \\
\text { Intervention } \\
\text { and 8-K } \\
\text { Filing Date }\end{array}$ & 575,196 & -53.424 & 588.806 & $-1,064$ & -552 & -70 & 425 & 1,064 \\
\hline $\begin{array}{l}\text { Length of 8-K } \\
\text { Filing } \\
\text { (Characters) }\end{array}$ & 575,190 & 548,488 & $2,123,165$ & 1,315 & 27,811 & 74,620 & 307,421 & $152,816,998$ \\
\hline
\end{tabular}

Our analysis mainly considers whether the change in leakage before and after the activist intervention differs between our treatment and control groups. This is known as a "difference in differences" design because we compare the change over time (difference \# 1) between treatment and control (difference \#2). We restrict our sample to "time windows" of 120 days on either side of the activist board appointment date. But we exclude the three weeks on either side of this date to ensure that our results are not driven by leakage of information regarding the settlement agreement itself.

The difference-in-differences design relies on the assumption that the treatment and control groups follow parallel 
trends over time-that is, in the absence of the activist settlement, changes in leakage over time would remain similar between the two groups. Qualitatively, there is no reason to suspect that activist funds choose targets that are more likely to experience greater information leakage in the months following the intervention. While we acknowledge, of course, that activist investors select targets based on characteristics such as relative historical performance, ${ }^{78}$ we see little basis to worry that those characteristics are correlated with time trends in information leakage. ${ }^{79}$ We also verify this assumption below.

In addition to a difference-in-differences design, we employ propensity-score matching to make it more likely that the treatment and control firms are as comparable as possible. Matching methods have become increasingly popular in empirical corporate governance research. ${ }^{80}$ These methods allow for forming pairs or small groups of firms who are similar on observable dimensions and compare only those firms to each other, effectively weighting by similarity. We match treatment and control firms based on observable covariates including the log of market capitalization, Amihud illiquidity, idiosyncratic volatility, the book-to-market ratio, whether the filing refers to a press release, 1-digit SIC code, as well as the following Form 8-K item disclosures: 81

- Item 1.01: Entry into a Material Definitive Agreement

78 See Cremers et al., supra note 1 , at 6.

79 To give an illustration of why a selection critique of this kind is unlikely to be a problem in this design, suppose that hedge funds select targets on the basis of poor governance, and suppose, in turn, that poor governance is correlated with insider trading activity. But in a difference-in-differences design, the results can only be biased by time-varying omitted variables. Thus, for this objection to be problematic it must be the case that hedge funds select targets for activist intervention on the basis of unobserved trends in increasing leakage. It is hard to imagine what such a trend might be, especially because, with 475 different activist directors gaining boardroom access at different points in time, this kind of time trend cannot merely be a spurious coincidence at a particular moment in calendar time-it must be a consistent trend throughout time.

80 See, e.g., K.J. Martijn Cremers, Lubomir P. Litov \& Simone M. Sepe, Staggered Boards and Long-Term Firm Value, Revisited, 126 J. FIn. ECON. 422, 434 (2017) (using a matching method to analyze long-term firm value and board structure).

81 Because we only have so much data, we are limited in our ability to match on high-dimensional covariates like Form 8-K item numbers in addition to a 4digit SIC code. The standard approach in this kind of situation is to "coarsen" the matching groups, i.e., to choose covariates at a sufficiently broad level of generality that the matching is feasible. See, e.g., Stefano M. Iacus, Gary King \& Giuseppe Porro, CEM: Software for Coarsened Exact Matching, 30 J. STAT. SOFTWARE 1, 1-27 (2009) (discussing a program that implements the coarsened exact matching algorithm). We apply this sort of coarsened matching by using 1-digit SIC code and choosing the most important categories of Form 8-K filings. 
- Item 2.02: Results of Operations and Financial Condition

- Item 5.02(a)-(b): Departure of Directors or Certain Officers

- Item 5.02(d): Election of Directors

- Item 7.01: Regulation FD Disclosure

- Item 8.01: Other Events

We allow up to five nearest neighbors so that results are not driven by arbitrarily close matches.

We empirically verify the validity of these matching methods in two ways. First, we perform a "balance test" examining whether the propensity-score matching succeeded in yielding a balanced treatment and control group. The results are shown in Table 3.

Table 3. Balance Test on Firm and Filing Characteristics. In this Table, we compare the means of each of the key covariates used in the matching design between treatment and control. The table shows the mean for each of the groups, the difference as a percentage of the treated group, the t-statistic of this difference, and the associated p-value. A p-value above .05 indicates that there is no statistically significant difference in the means of the two groups, indicating that the null hypothesis of balance on these observable characteristics cannot be rejected.

\begin{tabular}{lccccc} 
& \multicolumn{2}{c}{ Mean } & & & \\
& Treated & Control & $\begin{array}{c}\text { \% } \\
\text { bias }\end{array}$ & $\begin{array}{c}\text { t- } \\
\text { statistic }\end{array}$ & $\begin{array}{c}\text { p- } \\
\text { value }\end{array}$ \\
Amihud (2002) & 0.4259 & 0.43667 & -1.5 & -0.54 & 0.592 \\
Log Market Value & 13.212 & 13.209 & 0.1 & 0.04 & 0.97 \\
Contains "Press Release" & 0.60677 & 0.60437 & 0.5 & 0.15 & 0.882 \\
Idiosyncratic Volatility & 0.02851 & 0.02808 & 1.7 & 0.61 & 0.54 \\
$\begin{array}{l}\text { Book-to-Market Ratio } \\
\text { Item 1.01: Entry into a }\end{array}$ & -4.5058 & -4.5587 & 2.7 & 0.83 & 0.405 \\
$\begin{array}{l}\text { Material Definitive } \\
\text { Agreement }\end{array}$ & & & & & \\
Item 2.02: Results of & 0.16439 & 0.17236 & -2.2 & -0.64 & 0.519 \\
$\begin{array}{l}\text { Operations and Financial } \\
\text { Condition }\end{array}$ & & & & & \\
Ittem 5.02(a)-(b): Departure of & 0.28345 & 0.27974 & 0.8 & 0.25 & 0.803 \\
$\begin{array}{l}\text { Directors or Certain Officers } \\
\text { Item 5.02(d): Election of }\end{array}$ & 0.17641 & 0.17553 & 0.2 & 0.07 & 0.945 \\
$\begin{array}{l}\text { Directors } \\
\text { Item 7.01: Regulation FD }\end{array}$ & 0.24468 & 0.24697 & -0.6 & -0.16 & 0.872 \\
$\begin{array}{l}\text { Disclosure } \\
\text { Item 8.01: Other Events }\end{array}$ & 0.17094 & 0.16395 & 1.8 & 0.57 & 0.571 \\
& 0.23867 & 0.23539 & 0.8 & 0.23 & 0.816
\end{tabular}

In addition, we plot the density of the propensity score for the treatment and control groups. If the two groups are balanced 
on observable characteristics, the propensity score should appear similar between the two groups. Figure 4 shows this is indeed the case.

Figure 4. DEnsity of PROPEnsity Score. This Figure plots the empirical density of the propensity score for the treatment and control groups. As the Figure shows, the two groups are balanced on observable characteristics.

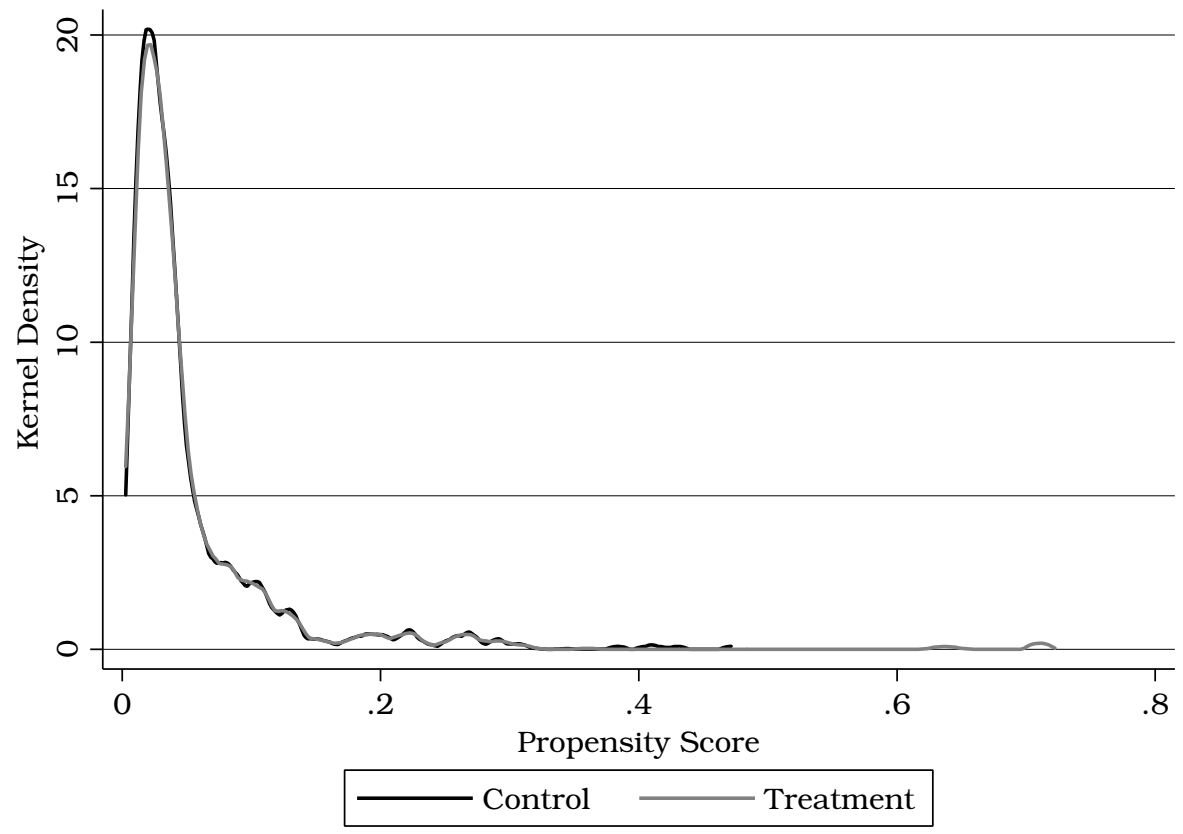

Finally, in the Online Appendix, we show that pre-trends on the leakage outcome for the treatment and control groups are parallel, which is an important condition for the kind of differencein-differences design that we employ here to be valid. Taken together, these results suggest that the leakage findings in this Article are not driven by differences in the kind of information firms are disclosing to the market. Satisfied that our identification assumption is consistent with the evidence, we now turn to measuring the effects of activist settlements, and the directors appointed pursuant to those settlements, on leakage at the firms that enter into those agreements.

E. Information Leakage after Activist Directors Gained Boardroom Access

We first consider whether the change in leakage before and after the date on which the activist settlement gives a new director access to the boardroom differs between our treatment and control firms. To evaluate this question, we perform a 
regression analysis which estimates the change in leakage from before to after the director is appointed to the board and compares that change between the treatment and control groups. Next, we seek to find if there are significant differences in leakage depending on who is appointed to the board (in particular, an independent person versus a hedge fund employee). As noted above, we code each director's identity on the basis of public searches and classify directors according to whether or not they are employees of the activist investor. ${ }^{82}$ Finally, we consider whether the post-settlement increases in leakage we identify vary depending on the presence or absence of confidentiality provisions in the settlement agreement. The differencein-differences coefficients from each of these estimations are shown in Table 5 using our primary specification and in Table 6 using our alternative truncation model.

TABLE 5. INFORMATION LEAKAGE. In this Table, we estimate the difference in the over-time change in leakage between the treatment and control groups. We show the results of OLS regression models in which the dependent variable is $l e a k_{i, t}$, the leakage for a particular Form 8-K filing, weighted by $\left|r_{t-5, t_{0}}^{i}\right|$ and the propensity-score weight. The sample is limited to Form $8-\mathrm{K}$ filings within a window of $[-120,-21]$ and $[+21,+120]$. The model is given by the following linear specification:

$$
\text { leak }_{i, t}=\beta_{0}+\beta_{1} d_{i}+\beta_{2} \text { post }_{t}+\beta_{3}\left(d_{i} \times \text { post }_{t}\right)+\epsilon_{i, t}
$$

where $d_{i}$ is an indicator variable equal to 1 if the $8-\mathrm{K}$ filing is in the treatment group; post $_{t}$ is an indicator variable equal to 1 if the 8-K filing occurred after the director appointment date; and $\varepsilon_{i, t}$ is a random error term. The coefficient of interest is $\beta_{3}$, which captures the over-time difference in leakage between the two groups. We cluster standard errors by firm-event to adjust for serial correlation in leakage. T-statistics are provided below correlation coefficients in parentheses. We use the following indicators of statistical significance: *** indicates $p<0.01$, ** indicates $p<0.05$, and ${ }^{*}$ indicates $p<0.10$.

82 The majority of securities filings related to settlement agreements specify the nature of the activist director's relationship, if any, with the activist. In addition, we found that the activist employee-appointees are typically senior executives of the activist, making identification of their relationship with the investor straightforward. Directors who are not employees of the activist, by contrast, are typically current or former senior executives in the target company's industry, making identification of their employment and expertise similarly straightforward. 


\begin{tabular}{|l|c|c|c|c|}
\hline & Leakage & Leakage & Leakage & Leakage \\
\hline Treatment x Post & $\mathbf{0 . 0 7 5 2}^{* *}$ & & & \\
\hline (t-statistic) & $\mathbf{( 2 . 1 7 )}$ & & & \\
\hline Hedge Fund x Post & & $\mathbf{0 . 0 9 9 4 * * *}$ & & \\
\hline (t-statistic) & & $\mathbf{( 2 . 9 2 )}$ & & \\
\hline Not Hedge Fund x Post & & -0.0225 & & \\
\hline (t-statistic) & & $(-0.27)$ & & \\
\hline $\begin{array}{l}\text { Employee-Director x } \\
\text { Post }\end{array}$ & & & $\mathbf{0 . 0 7 6 0 * *}$ & \\
\hline (t-statistic) & & & $\mathbf{( 2 . 0 1 )}$ & \\
\hline $\begin{array}{l}\text { Non-Employee-Director } \\
\text { x Post }\end{array}$ & & & 0.0731 & \\
\hline (t-statistic) & & & $(1.28)$ & \\
\hline $\begin{array}{l}\text { No Information-Sharing } \\
\text { Rule x Post }\end{array}$ & & & & $\mathbf{0 . 1 1 0 7 * *}$ \\
\hline (t-statistic) & & & & $\mathbf{( 2 . 3 4 )}$ \\
\hline $\begin{array}{l}\text { Information-Sharing } \\
\text { Rule x Post }\end{array}$ & & & & 0.0631 \\
\hline (t-statistic) & & & & $(1.17)$ \\
\hline Observations & 9,414 & 9,414 & 9,414 & 9,414 \\
\hline
\end{tabular}

TABlE 6. InFormation LEAKAge (Alternative TRUnCATION SPECIFICATION). In this Table, we estimate the difference in the over-time change in leakage between the treatment and control groups. We show the results of truncated regression models (Long, 1997) in which the dependent variable is leak $k_{i, t}$, the leakage for a particular Form 8-K filing, for those filings where $0<$ leak $_{i, t}<1$. The sample is limited to Form 8-K filings within a window of $[-120,-21]$ and $[+21,+120]$. The model is given by the following linear specification:

$$
\text { leak }_{i, t}=\beta_{0}+\beta_{1} d_{i}+\beta_{2} \text { post }_{t}+\beta_{3}\left(d_{i} \times \text { post }_{t}\right)+\gamma^{\prime} x_{i, t}+\epsilon_{i, t}
$$

where $d_{i}$ is an indicator variable equal to 1 if the 8 -K filing is in a treatment group; post $t_{t}$ is an indicator variable equal to 1 if the 8-K filing occurred after the director appointment date; $\mathrm{x}_{\mathrm{i}, \mathrm{t}}$ is a vector of time-varying covariates: the decile of the firm's market value, idiosyncratic volatility, the Amihud (2002) illiquidity measure, and the log of the firm's book-to-market ratio; each as of the month preceding the Form 8-K filing, or current year in the case of the book-to-market ratio, as well as filing-level covariates: the filing length and fixed effects for item numbers; and $\varepsilon_{i, t}$ is a random error term. The coefficient of interest is $\beta_{3}$, which captures the over-time difference in leakage between the two groups. We cluster standard errors by firm-event to adjust 
for serial correlation in leakage. T-statistics are provided below correlation coefficients in parentheses. We use the following indicators of statistical significance: ${ }^{* * *}$ indicates $p<0.01$, ** indicates $p<0.05$, and ${ }^{*}$ indicates $p<0.10$.

\begin{tabular}{|c|c|c|c|c|}
\hline & Leakage & Leakage & Leakage & Leakage \\
\hline Treatment x Post & $0.2535 * * *$ & & & \\
\hline (t-statistic) & (2.73) & & & \\
\hline Hedge Fund $x$ Post & & $0.2701^{* * *}$ & & \\
\hline (t-statistic) & & $(2.68)$ & & \\
\hline Not Hedge Fund $x$ Post & & 0.2238 & & \\
\hline (t-statistic) & & $(0.85)$ & & \\
\hline $\begin{array}{l}\text { Employee-Director } x \\
\text { Post }\end{array}$ & & & $0.2406^{* *}$ & \\
\hline (t-statistic) & & & $(2.17)$ & \\
\hline $\begin{array}{l}\text { Non-Employee- } \\
\text { Director x Post }\end{array}$ & & & $0.2907^{*}$ & \\
\hline (t-statistic) & & & $(1.74)$ & \\
\hline $\begin{array}{l}\text { No Information- } \\
\text { Sharing Rule x Post }\end{array}$ & & & & $0.4985^{* * *}$ \\
\hline (t-statistic) & & & & (3.28) \\
\hline $\begin{array}{l}\text { Information-Sharing } \\
\text { Rule x Post }\end{array}$ & & & & 0.0453 \\
\hline (t-statistic) & & & & $(0.29)$ \\
\hline Observations & 23,002 & 23,002 & 23,002 & 23,002 \\
\hline
\end{tabular}

In Tables 5 and 6 , the bold faced entries across from "Treatment $x$ Post" show that settlement firms experience an average increase of 7.5 (in Table 5) or 25 (in Table 6) percentage points in leakage above that of the control firms over a fourmonth window following the appointment of the activist director(s) to the board. 83 The variation in the two estimates is driven by the different weighting and truncation procedure.

83 Does this effect persist over the long-term? We can think of at least two reasons why leakage is unlikely to persist many months into the future. One is that the activist hedge fund, having achieved its goal of appointing directors to the target's board, may swiftly bring about the desired financial or operating changes and then shift its attention elsewhere. Activists typically sell their positions after a holding period of around one year. A second possibility is, as suggested in the Theoretical Appendix, that if the leakage effect is driven by illegal conduct, the probability of detection may increase over time, thus deterring leakage increasingly as time progresses. We considered whether the effect we measure persists over a longer one-year window $(-365,+365)$ following the appointment of the directors to the board. We estimated the same specification described above over that longer period. Unlike the results from our short-term sample, we found that the difference-in-difference coefficient is not significantly different when estimating leakage over a longer window following the activist intervention. 
The former estimate is smaller because it includes many observations of "negative" leakage (i.e., wrong-way trading), while the latter excludes those cases via truncation. These two models simply take different approaches to accounting for cases that do not easily fit the "percentage of price change" interpretation of the leakage ratios. In both specifications, this difference is statistically significant at the $1 \%$ level, meaning the probability that this result was obtained by random chance is less than $1 \%$.

Similarly, firms that are targets of activist investors experience an increase in leakage of 9.94 percentage points (in Table 5) or 27.9 percentage points (in Table 6), on average, above that of the control firms, over the four-month window following the appointment of the activist director(s) to the board. As before, the variation is driven by the difference in truncation. In both specifications, this difference is statistically significant at the $1 \%$ level. On the other hand, the row labeled "Not Hedge Fund $x$ Post" shows that the estimated over-time increase in leakage for firms that are the targets of non-hedge fund investors is inconsistently estimated, ranging from -0.0225 to 22.4 percentage points. However, none of these estimates are statistically significant at the $1 \%, 5 \%$ or even $10 \%$ level. Thus, there is a high probability the non-hedge fund estimates were obtained by random chance alone. ${ }^{84}$ Our findings are consistent with the conjecture that information leakage increases with the intervention of hedge fund activists in a way that differs meaningfully from interventions by other investors, but we reiterate that this statistical finding does not establish illegal conduct or a violation of Rule $10 \mathrm{~b}-5$.

Next, we compare the over-time difference in leakage between the control group and two treatment groups: those where employees of the activist are appointed to the target's board pursuant to the settlement agreement and those where the appointed directors are not employees of the activist. The bold-faced row labeled "Employee Director Dummy x Post" shows that settlements which provide for the appointment of at least one director who is an employee of the acquiror experience an increase of 7.6 or 24 percentage points in leakage, on average, above that of the control firms, over the four-month window following the appointment of the activist director(s) to the board. This difference is statistically significant at the 5\%

84 However, an F-test does not indicate that the difference in these coefficients is statistically significant. An "F-test" is a statistical test of the hypothesis that the difference in regression coefficients was caused by random chance alone. 
level. On the other hand, the row labeled "Not Employee Director Dummy x Post" shows that the estimated increase in leakage for settlements which provide solely for the appointment of non-employee directors is statistically insignificant in the primary specification, and only marginally significant at the 10\% level in the truncated specification. ${ }^{85}$ Taken together, these results suggest that the non-employee director estimates were obtained by random chance alone. The only leakage result that is consistently statistically meaningful is that of employee directors.

Although the reason for this heterogeneity deserves closer consideration, we offer several possibilities for further study. First, to the extent that the mechanism producing the leakage we observe is trading facilitated by directors, activist investor employees-usually finance professionals-are more likely than non-employees to have access either to (i) trading capital of the magnitude necessary to produce the stock price movements that we observe, or (ii) professional traders willing to act as their agents (presumably for a share of the profits). Second, to the extent that the mechanism for disseminating confidential information is loose gossip, hedge fund employees (either directors or fellow employees in contact with them) live in an environment of traders where the value of such information is well understood (and where reciprocal benefits and tips may be expected in the future by those who tip today). We will call this the "favor bank" explanation, as it suggests that there may be norms of reciprocity observed by many in the financial world who engage in such information sharing. Third, it is possible that either the reputational loss associated with improper facilitation of informed trading or the acceptance of moral norms that preclude participation in such trading is higher for nonemployees-typically industry experts and often current or former officers of large public companies - than for less visible activist employees. Arguably, such experts and executives are either more easily deterred or more morally inhibited. We do not assert, however, that we have proven any of these conjectures.

We now consider whether these post-settlement increases in leakage differ with information-sharing provisions in the settlement agreement. As noted above, we classified each settlement agreement with respect to several information-sharing provisions, including whether the agreement contains an ex-

85 As with the prior result, an F-test does not indicate that the difference in these coefficients is statistically significant. 
press rule on information sharing, refers to an informationsharing rule in a separate confidentiality agreement, or refers to a generic policy on information sharing. As before, we consider two treatment groups: those with either an express rule on information sharing or a reference to an information-sharing rule in a separate confidentiality agreement and those without either of these provisions. In our primary specification, the coefficient on the latter is twice as large as the former. ${ }^{86}$ In our alternative specification, the agreements lacking a rule restriction on information sharing have nearly twelve times as much leakage as those with a rule on information sharing, while the statistical significance of the former is extremely high whereas the latter is not even close to significant. In the alternative specification, the standard statistical test (known as an " $\mathrm{F}$ test") indicates that the difference in these coefficients is statistically significant.

In other words, the leakage difference correlates closely with whether activist settlements contain either an express rule on information sharing or a reference to an informationsharing rule in a separate confidentiality agreement. We do not suggest that this correlation is causal-we are not claiming that the presence of such a rule deters leakage. Rather, one possible explanation for this difference may be that activists differ in their willingness to share material, nonpublic information and the market can distinguish those more likely to maintain confidentiality (who also happen to be the ones most likely to insert such a confidentiality provision in their settlement agreements).

One general objection to our analysis thus far is that the control group may not be sufficiently comparable to the treatment group(s), even with the propensity-score matching, because these control firms are not undergoing the kind of farreaching corporate change that takes place following a settlement agreement. 87 This concern essentially states the relevant counterfactual for our causal analysis: would information leakage have increased but for the appointment of directors pursuant to the settlement agreement or but for the enactment of operational changes pursuant to the hedge fund's demands? The latter implies that the leakage effect we identify is caused by hedge fund activism but not necessarily the settlement or

86 However, an F-test does not indicate that the difference in these coefficients is statistically significant.

87 We thank Lucian Bebchuk and Alon Brav for independently raising this important concern. 
appointment of directors to the boardroom. This still raises important policy concerns, but the mechanism is different.

We have taken this objection seriously and found two tests by which to measure if it does indeed impact our results. First, we utilize an alternative control group consisting of those firms which experienced a Schedule 13-D filing but did not engage in a settlement agreement. On average, these firms are undergoing operational change in response to hedge fund activism and thus supply a counterfactual that more precisely isolates the settlement itself (though at the cost of some statistical power, as this sample is much smaller). The challenge is choosing the relevant "settlement" date in these cases, as both the treatment and control groups had a 13-D filing prior to the settlement. Our primary approach is to add the median distance between a 13-D and settlement filing (148 calendar days) to this alternative control group's 13-D filing date, though we also randomly sampled a 13-D settlement date distance and obtained very similar results. We apply the same propensity-score matching as previously (again, obtaining balance across the covariates), and present the results of our analysis with this alternative control group in Table 7.

TABLE 7. InFORMATION LEAKAGE (13-D CONTROL GROUP). In this Table, we estimate the difference in the over-time change in leakage between the treatment and an alternative control group consisting of firms subject to activist engagements that did not result in a settlement, where the "activist director appointment date" for the control firms is equal to the 13-D date plus the median difference between the settlement and 13-D date in the treatment group. We show the results of OLS regression models in which the dependent variable is $l e a k_{i, t}$, the leakage for a particular Form 8-K filing, weighted by $\left|r_{t-5, t_{0}}^{i}\right|$ and the propensity-score weight. The sample is limited to Form 8-K filings within a window of $[-120,-21]$ and $[+21,+120]$. The model is given by the following linear specification:

$$
\text { leak }_{i, t}=\beta_{0}+\beta_{1} d_{i}+\beta_{2} \text { post }_{t}+\beta_{3}\left(d_{i} \times \text { post }_{t}\right)+\epsilon_{i, t}
$$

where $d_{i}$ is an indicator variable equal to 1 if the 8 -K filing is in a treatment group (see below); post $t_{t}$ is an indicator variable equal to 1 if the 8-K filing occurred after the director appointment date; and $\varepsilon_{i, t}$ is a random error term. The coefficient of interest is $\beta_{3}$, which captures the over-time difference in leakage between the two groups. We cluster standard errors by firm-event to adjust for serial correlation in leakage. T-statistics are provided below correlation coefficients in parentheses. 
We use the following indicators of statistical significance: *** indicates $p<0.01,{ }^{* *}$ indicates $p<0.05$, and ${ }^{*}$ indicates $p<$ 0.10 .

\begin{tabular}{|c|c|c|c|c|}
\hline & Leakage & Leakage & Leakage & Leakage \\
\hline Treatment x Post & $0.1099^{* * *}$ & & & \\
\hline (t-statistic) & (2.59) & & & \\
\hline Hedge Fund $x$ Post & & $0.1362^{* * *}$ & & \\
\hline (t-statistic) & & (3.25) & & \\
\hline Not Hedge Fund $\mathrm{x}$ Post & & 0.0027 & & \\
\hline (t-statistic) & & $(0.03)$ & & \\
\hline $\begin{array}{l}\text { Employee-Director } \mathrm{x} \\
\text { Post }\end{array}$ & & & $0.1101 * *$ & \\
\hline (t-statistic) & & & $(2.44)$ & \\
\hline $\begin{array}{l}\text { Non-Employee-Director } \\
\text { x Post }\end{array}$ & & & $0.1096^{*}$ & \\
\hline (t-statistic) & & & $(1.76)$ & \\
\hline $\begin{array}{l}\text { No Information- } \\
\text { Sharing Rule x Post }\end{array}$ & & & & $0.1012 *$ \\
\hline (t-statistic) & & & & $(1.68)$ \\
\hline $\begin{array}{l}\text { Information-Sharing } \\
\text { Rule x Post }\end{array}$ & & & & $0.1434^{* * *}$ \\
\hline (t-statistic) & & & & $(2.71)$ \\
\hline Observations & 5,364 & 5,364 & 5,364 & 5,364 \\
\hline
\end{tabular}

Table 7 shows that the results with this alternative control group are generally consistent with our prior findings. The difference-in-differences coefficient for the treatment group is positive, statistically significant, and of a similar magnitude as the prior control group. There is a large numerical difference between the hedge fund and non-hedge fund groups, just as before. The employee-director group is statistically significant, whereas the non-employee-director group is not. The only difference is that the prior no information-sharing rule finding reverses direction in this alternative control group specification.

To further shed light on the possibility that information leakage is driven by the activist engagement rather than the appointment of directors pursuant to the settlement, we look within the treatment group and compare information leakage after the Schedule 13-D filing (but before the appointment of nominee directors) and leakage after the appointment of these directors pursuant to the settlement. The latter period allows us to isolate the additional impact of the director appointment as a possible conduit for information leakage. Specifically, we 
compare leakage for Form 8-Ks filed between two periods: (1) a "pre" period that begins seven days after the Schedule 13-D filing and ends seven days before the director appointment to the board pursuant to the settlement and (2) a "post" period that begins seven days after the director appointment and ends 120 days after. In this specification, we simply compare leakage between these two periods. The results are given in Table 8 , which contains a column for each of the treatment groups considered thus far: all settlements, hedge-fund only, employee-director only, and no information-sharing only.

TABLE 8. InFORMATION LEAKAgE: AFTER 13-D (BUT BEFORE APPOINTMENT) VS. AFTER APPOINTMENT. In this Table, we estimate the difference in information leakage following the 13-D filing to leakage following the appointment of directors pursuant to a settlement for the treatment group only. Specifically, we compare leakage between two periods: a "pre" and "post" period, defined as follows:

Pre $=[13-\mathrm{D}$ Filing +7 days, Director Appointment -7 days $]$ Post $=[$ Director Appointment +7 days, Director Appointment + 120 days]

We show the results of OLS regression models in which the dependent variable is $l_{e} a k_{i, t}$, the leakage for a particular Form 8 -K filing, weighted by $\left|r_{t-5, t_{0}}^{i}\right|$. The model is given by the following linear specification:

$$
\text { leak }_{i, t}=\beta_{0}+\beta_{1} \text { post }_{t}+\epsilon_{i, t}
$$

where post $_{t}$ is an indicator variable equal to 1 , if the 8 -K filing occurred after the director appointment date; and $\varepsilon_{i, t}$ is a random error term. The coefficient of interest is $\beta_{1}$, which captures the over-time difference in leakage between the 13-D and settlement date. We cluster standard errors by firm-event to adjust for serial correlation in leakage. T-statistics are provided below correlation coefficients in parentheses. We use the following indicators of statistical significance: $* * *$ indicates $p<$ $0.01{ }^{* *}$ indicates $p<0.05$, and ${ }^{*}$ indicates $p<0.10$. 


\begin{tabular}{|l|c|c|c|c|}
\hline & $\begin{array}{c}\text { All } \\
\text { Settlement }\end{array}$ & $\begin{array}{c}\text { Hedge } \\
\text { Fund Only }\end{array}$ & $\begin{array}{c}\text { Employee- } \\
\text { Director } \\
\text { Only }\end{array}$ & $\begin{array}{c}\text { No Information- } \\
\text { Sharing } \\
\text { Provisions Only }\end{array}$ \\
\hline Post & $\mathbf{0 . 0 5 3 3}^{* *}$ & $\mathbf{0 . 0 7 4 1} * * *$ & $\mathbf{0 . 0 4 8 8 *}$ & $\mathbf{0 . 0 6 5 1}$ \\
\hline & $\mathbf{( 2 . 2 2 )}$ & $\mathbf{( 2 . 8 6 )}$ & $\mathbf{( 1 . 6 5 )}$ & $\mathbf{( 1 . 5 1 )}$ \\
\hline & & & & \\
\hline (Intercept) & $0.6672^{* * *}$ & $0.6673^{* * *}$ & $0.6789^{* * *}$ & $0.6723^{* * *}$ \\
\hline & $(49.59)$ & $(44.89)$ & $(45.42)$ & $(32.13)$ \\
\hline & & & & \\
\hline Observations & 7,411 & 5,758 & 4,744 & 3,007 \\
\hline
\end{tabular}

As Table 8 shows, there is an increase in information leakage from the first period (between the Schedule 13-D filing to just before the appointment) to the second period (following just after the appointment of the activist director). This increase is statistically significant at the $1 \%$ or $5 \%$ level in two of the four specifications, and at the 10\% level in another. The magnitude of the increase is roughly on the order of 5-7 percentage points, or $8-11 \%$ of the constant term. These results provide further evidence that the increase in leakage is not driven solely by the activist engagement per se, but seems to be following the appointment of the directors to the board pursuant to the settlement agreement.

\section{F. Options Trading}

A possible rejoinder to the foregoing evidence of informed trading is that much of the communication between a lead activist fund and its allies may be innocuous and immaterial. For example, a sophisticated trader may ask the activist fund "How is your campaign at XYZ Industries going?" and receive the non-specific response: "Great! We are making real progress." This response may influence the sophisticated trader to buy, but it is probably legally immaterial. Still, the problem with this explanation as a rebuttal to our view that informed trading is occurring is that the sophisticated trader needs to know with some precision when material information will reach and affect the market. For example, such a trader could not sensibly buy a thirty-day option on XYZ Industries, based on the above general assurance, because the sophisticated trader would not know from it when market-moving news will reach the market.

For an informed trader, options are the most efficient way to trade, giving a greater return at a lower cost. Indeed, a number of studies have established that informed traders are 
active in the options market 88 and that options prices do predict future stock returns. ${ }^{89}$ For our purposes, it is particularly useful to focus on how informed traders trade in the options market. The best evidence here is that they prefer to take long positions only in anticipation of unscheduled news releases and that they avoid trading on scheduled news events (such as earnings releases). ${ }^{90}$ Form $8-\mathrm{K}$ filings are, by definition, unscheduled news releases (which must generally be filed within four business days after a defined event occurs). Thus, if we find profitable trading in the options market based on trades entered into prior to a Form 8-K filing, this would be consistent with the general pattern of informed trading in the options market. But given the short timing requirements for the filing of a Form 8-K, a trader cannot expect to profit from thirty-day options based only on vague, immaterial gossip. One must trade quickly to profit from advance knowledge of the content of a prospective Form 8-K filing, and this requires that the trader know approximately when the announcement will occur. Further, a general sense that things are going well (or poorly) does not imply that there will soon be any filing (and certainly not a Form 8-K filing) that will move the market price. To sum up, the trader must have hard and specific information (including as to the announcement date) to profit from trading on options.

In that light, we examined whether there is greater trading in stock options of target firms following an activist settlement agreement. Because there may be hundreds or even thousands of stock option contracts written on any given firm's stock over time, it was necessary to employ a specially focused form of analysis. We downloaded options data from the OptionsMetrics IvyDB database only for firms which executed an activist settlement and divided these options into two groups, limiting our analysis to a window of one year on either side of the settlement agreement.

The first group consists of options written on settlement firms which "overlap" a Form 8-K disclosure. By "overlap," we

88 See Jun Pan \& Allen M. Poteshman, The Information in Option Volume for Future Stock Prices, 19 REV. FIn. STUD. 871 (2006); Martijn Cremers, Andrew Fodor \& David Weinbaum, How Do Informed Option Traders Trade? Option Trading Activity, News Releases, and Stock Return Predictability, (last revised Sept. 21, 2017), https://papers.ssrn.com/sol3/papers.cfm?abstract_id=2544344 [https:/ /perma.cc/4JJM-VDBB] (surveying literature on informed trading in options market).

89 See Martijn Cremers \& David Weinbaum, Deviations from Put-Call Parity and Stock Return Predictability, 45 J. FIN. \& QUANTITATIVE ANALYSIS 335, 337 (2010).

90 See Cremers, Fodor \& Weinbaum, supra note 88, at 24. Earnings releases are both scheduled and generally released on a Form 10-Q. 
mean that the option price is quoted before the Form 8-K filing but the option expires after the Form $8-\mathrm{K}$ was subsequently filed. For example, suppose that the Form 8-K is filed on January 10. An option that is quoted on January 1 and expires on January 31 would "overlap" the Form 8-K. An option that expires on January 9 would not overlap the Form 8-K; neither would any option that is quoted on January 11 . The second group consists of options written on settlement firms which do not overlap a Form 8-K disclosure.

An increase in trading volume for options that overlap a Form 8-K disclosure is consistent with trading on the basis of material nonpublic information. On average, these options increase in value upon the filing of the Form 8-K disclosure. Then, we employ regression analysis to compare the difference in trading volume between overlapping and non-overlapping options, before and after the directors are appointed to the board pursuant to the settlement agreement. We present these "difference in differences" results in Table 9.

TABle 9. EfFects of Activist SetTlements on Options Trading (TREATMENT ONLY). In this Table, we estimate the difference in the over-time change in options trading between options which overlap a Form 8-K filing and those that do not overlap a Form 8 -K filing. This Table reports the results of a difference-indifferences specification, which we estimate by ordinary least squares as follows:

$$
\log \left(\operatorname{vol}_{i, t}\right)=\beta_{1} d_{i}+\beta_{2} \text { post }_{t}+\beta_{3}\left(d_{i} \times \text { post }_{t}\right)+\gamma^{\prime} x_{i, t}+\phi_{i}+\epsilon_{i, t}
$$

where $v l_{i, t}$ is the trading volume in option $i$ as of month $t$; $d_{i}$ is a dummy variable equal to 1 if an option overlaps a Form $8-\mathrm{K}$ disclosure; post $_{t}$ is a dummy variable equal to 1 if month $t$ is after the director appointment date; $\mathrm{x}_{\mathrm{i}, \mathrm{t}}$ is a vector of timevarying option covariates: option strike price, delta, gamma, vega, and implied volatility; $\phi_{i}$ is a fixed effect for firm $i$; and $\varepsilon_{i, t}$ is a random error term. The coefficient of interest is $\beta_{3}$, which captures the over-time difference in log trading volume between the two groups. We cluster standard errors by option to address serial correlation in trading volume. We use the following indicators of statistical significance: ${ }^{* * *}$ indicates $p<0.01$, ** indicates $p<0.05$, and ${ }^{*}$ indicates $p<0.10$. 


\begin{tabular}{|c|c|c|c|c|}
\hline & $\begin{array}{c}\text { Log of } \\
\text { Trading } \\
\text { Volume } \\
\text { (no controls) }\end{array}$ & $\begin{array}{l}\text { Log of } \\
\text { Trading } \\
\text { Volume } \\
\text { (some } \\
\text { controls) }\end{array}$ & $\begin{array}{l}\text { Log of } \\
\text { Trading } \\
\text { Volume } \\
\text { (more } \\
\text { controls) }\end{array}$ & $\begin{array}{c}\text { Log of } \\
\text { Trading } \\
\text { Volume } \\
\text { (all controls) }\end{array}$ \\
\hline $\begin{array}{l}\text { Overlapping } \\
\text { (Difference from } \\
\text { Non-Overlapping) }\end{array}$ & $-0.8144^{* * *}$ & $-0.8178^{* * *}$ & $-0.2481^{* * *}$ & $-0.2329 * * *$ \\
\hline (t-statistic) & $(-32.69)$ & $(-33.36)$ & $(-9.11)$ & $(-8.58)$ \\
\hline $\begin{array}{l}\text { Post (Difference } \\
\text { from Pre) }\end{array}$ & $-0.4264^{* * *}$ & $-0.5230 * * *$ & $-0.3921^{* * *}$ & $-0.4203^{* * *}$ \\
\hline (t-statistic) & $(-15.95)$ & $(-19.34)$ & $(-14.39)$ & $(-15.47)$ \\
\hline $\begin{array}{l}\text { Overlapping } x \\
\text { Post (Difference } \\
\text { in Differences) }\end{array}$ & $0.2318^{* * *}$ & $0.2780 * * *$ & $0.1503^{* * *}$ & $0.1685^{* * *}$ \\
\hline (t-statistic) & (6.84) & (8.27) & (4.66) & (5.25) \\
\hline Strike Price (Log) & & $-0.4942^{* * *}$ & $-0.0575^{*}$ & $0.2791^{* * *}$ \\
\hline (t-statistic) & & $(-15.14)$ & $(-1.82)$ & (7.67) \\
\hline Option Delta & & $0.2763^{* * *}$ & $0.3289 * * *$ & $0.3371^{* * *}$ \\
\hline (t-statistic) & & (15.37) & (19.96) & $(20.56)$ \\
\hline Option Gamma & & & $1.8129 * * *$ & $2.0393^{* * *}$ \\
\hline (t-statistic) & & & $(23.41)$ & $(25.41)$ \\
\hline Option Vega & & & $-0.0592 * * *$ & $-0.0574 * * *$ \\
\hline (t-statistic) & & & $(-32.43)$ & $(-31.77)$ \\
\hline Implied Volatility & & & & $1.2712^{* * *}$ \\
\hline (t-statistic) & & & & $(18.42)$ \\
\hline (Intercept) & $4.1628^{* * *}$ & $9.2969 * * *$ & $4.5731^{* * *}$ & 0.5585 \\
\hline (t-statistic) & $(199.57)$ & $(27.26)$ & $(13.76)$ & $(1.41)$ \\
\hline Observations & 251,450 & 251,450 & 251,450 & 251,450 \\
\hline
\end{tabular}

In Table 9, the bold-faced row labeled "Treatment $\mathrm{x}$ Post (Difference in Differences)" shows that settlement firms experience an over-time increase of 16-23 log points in trading volume, on average, of options that overlap Form 8-K filings, as compared to those that do not overlap Form 8-K filings. This difference is statistically significant at the $1 \%$ level. This evidence is consistent with the conjectures that tippees had specific information and knew approximately when it would be released to the market.

\section{G. Effect on Bid-Ask Spreads}

Next, we consider whether bid-ask spreads widen following activist settlements that lead to the appointment of directors to the target company's board, consistent with the theoretical predictions described in this Article. To do so, we obtained monthly bid-ask spreads from CRSP for each of the stocks in our treatment and control groups, following the same method 
as discussed above for calculating the "director appointment date" for each control group. For consistency with the leakage analysis, we exclude a 21-day window immediately preceding and following the settlement (though our results change very little if these days are included). To ensure our results are not driven by differences in bid-ask spreads arising far from the settlement, we limit the sample to monthly bid-ask spreads within short windows around the settlement date: 90, 120, 150 and 180 calendar days. Table 10 presents the results.

TABle 10. Activist SeTtlements AND BID-AsK SpREads. In this Table, we estimate the difference in the over-time change in bid-ask spreads between the treatment and the control groups. This Table reports the results of a difference-in-differences specification, which we estimate by ordinary least squares as follows, weighting by the propensity-score weight:

$$
\text { spread }_{i, t}=\beta_{0}+\beta_{1} d_{i}+\beta_{2} \text { post }_{t}+\beta_{3}\left(d_{i} \times \text { post }_{t}\right)+\epsilon_{i, t}
$$

where $\operatorname{spread}_{i, t}$ is the bid-ask spread divided by the closing price of firm $i$ 's stock at month $t ; d_{i}$ is a dummy variable equal to 1 if the firm appointed an activist director pursuant to a settlement agreement; post $_{t}$ is a dummy variable equal to 1 if month $t$ is after the director appointment date; and $\varepsilon_{i, t}$ is a random error term. The coefficient of interest is $\beta_{3}$, which captures the over-time difference in bid-ask spreads between the two groups. We cluster standard errors by firm to address serial correlation in spreads. 


\begin{tabular}{|c|c|c|c|c|}
\hline & $\begin{array}{c}{[-90,-21]} \\
\text { vs. } \\
{[+21,+90]}\end{array}$ & $\begin{array}{c}{[-120,-21]} \\
\text { vs. } \\
{[+21,+120]}\end{array}$ & $\begin{array}{c}{[-180,-21]} \\
\text { vs. } \\
{[+21,+180]}\end{array}$ & $\begin{array}{c}{[-270,-21]} \\
\text { vs. } \\
{[+21,+270]}\end{array}$ \\
\hline Treatment & $-0.0023^{*}$ & $-0.0021^{*}$ & -0.0014 & -0.0011 \\
\hline (t-statistic) & $(-1.68)$ & $(-1.73)$ & $(-1.26)$ & $(-1.16)$ \\
\hline Post & $-0.0029 * *$ & $-0.0025^{* * *}$ & $-0.0022^{* * *}$ & $-0.0020^{* * *}$ \\
\hline (t-statistic) & $(-2.55)$ & $(-2.58)$ & $(-2.62)$ & $(-2.77)$ \\
\hline Treatment x Post & $0.0033^{* *}$ & $0.0034 * * *$ & $0.0033^{* * *}$ & $0.0035^{* * *}$ \\
\hline (t-statistic) & $(2.58)$ & $(2.97)$ & (3.16) & (3.67) \\
\hline (Intercept) & $0.0086^{* * *}$ & $0.0083^{* * *}$ & $0.0076^{* * *}$ & $0.0074 * * *$ \\
\hline & $(7.02)$ & (8.06) & $(8.47)$ & $(9.51)$ \\
\hline Observations & 9,252 & 13,195 & 20,910 & 32,576 \\
\hline
\end{tabular}

In Table 10, the bold-faced row labeled "Treatment $\mathrm{x}$ Post (Difference in Differences)" shows that settlement firms experience an over-time average increase of 0.33-0.35 percentage points in the bid-ask spread for each individual trade. This difference is statistically significant at the 1\% level in most specifications. To get a sense for the magnitude of this effect, we multiply the monthly raw bid-ask spread for each firm's stock by the number of shares traded in that month and obtain an average difference-in-differences increase of $\$ 43,325$ per firm-month-event in the "Treatment $x$ Post" group for the sixmonth specification $[-180,-21]$ vs. $[+21,+180]$. Multiplying by $\mathrm{n}=8,034$ firm-month-events in the "Treatment $\mathrm{x}$ Post" group yields a total approximate increase of \$348 million in bid-ask spreads over this six-month period window.

Finally, we note that, although the point estimates for this difference may seem relatively small, as Glosten \& Putnins point out, ${ }^{91}$ the social welfare losses associated with an effect like this one can be magnified by the downstream effects of

91 See Lawrence R. Glosten \& Talis J. Putnins, Welfare Costs of Informed Trade, (Aug. 23, 2016), https://poseidon01.ssrn.com/delivery.php?ID=62208 70090290711041010140650160110240220420100140330200880710760770 910960910831110050111180300020071130080880920000731111120900 01006043079004121101020117093079102054007078095080003082007074 $113072119126024108105066123127100069075102117026025092118096 \&$ EXT=pdf [https://perma.cc/C8U4-DE7N]. 
expanded bid-ask spreads in hindering-or making excessively expensive-mutually beneficial transactions. This result is consistent with the possibility that, whatever the private benefits obtained by directors or others following activist settlements, these benefits come with a corresponding social cost: wider bid-ask spreads that potentially deprive other investors of transactions in the company's stock that would otherwise occur. While we recognize that there is substantial uncertainty regarding the precise magnitude of this social cost, our findings do suggest that the use of activist settlement agreements-and the access to the boardroom that comes with them-carries a cost for public-company investors.

\section{III}

\section{IMPLICATIONS OF FINDINGS AND POSSIBLE REFORMS}

\section{A. Informed Trading and Hedge Fund Activism}

What is driving hedge fund activism? Is it just that activist funds are maximizing value for their fellow shareholders? Or is there more? In a simple model of activism, activists' funds gain or lose based on the stock prices of the target firms in which they invest. If the activist fund buys stock in the target firm, pushes for changes in its operations, staff or business model, and, in response, the target's stock price rises, few would deny that the activist benefitted the other shareholders. But if activist engagements culminating in the appointment of fundnominated directors are accompanied by informed trading (whether or not unlawful), then activism is receiving a second source of profit-in effect a special subsidy from informed trading. Thus, some activist engagements may be motivated (at least on the margin) not simply by efficiency considerations, but by the knowledge that the appointment of a director will give them access to material, nonpublic information. If this subsidy from informed trading is significant, it should logically cause an increase in the number of activist engagements, even if these engagements did not produce value for the other shareholders. To illustrate, suppose an activist fund expends $\$ 100,000$ (which is not reimbursed) over a six-month period and eventually appoints two directors to the target's board. Assume further that the stock price moves up and down in a volatile fashion over the six-month period following their appointment to the board, but ultimately no long-term increase in the target's stock price results. Shareholders in this target thus gain nothing (and probably bear some costs in the form of the legal expenses incurred by their company and the diverted ex- 
ecutive time). Assume finally that the activist (or its allies) make $\$ 500,000$ in profits from informed stock trading in the secondary market over this interval. As a result, the entire transaction produces no gain for shareholders generally (and probably produces some social waste), but it does yield a significant private benefit. When private gains cause public waste the result is socially inefficient.

The bottom line is that pervasive access to material, nonpublic information gives rise to an invisible subsidy to activism that logically should both inflate the rate of activist engagements and encourage (on the margin) at least some otherwise inefficient engagements (such as the one discussed above) that do not generate value for the other shareholders (but do generate profits for the informed traders). To be sure, this does not mean that hedge fund activism is itself undesirable or inefficient, but only that it is receiving a perverse subsidy.

Still, how is this subsidy received and allocated? Normally, the activist signs a standstill agreement with the target firm. ${ }^{92}$ But this may be less a barrier than it first appears, for several reasons. First, standstill agreements generally do not prevent short selling or trading in put and call options (which are the least costly way of exploiting material nonpublic information). Second, although private settlement agreements vary substantially in the restrictions they impose, most do not expressly bar trading by the activist's employees or agents, and relatively few require the target company's consent to the sharing of confi-

92 As noted earlier, the Bebchuk study finds that a standstill provision in settlement agreements is "almost universal." Bebchuk et al., supra note 14, at 6 . Still, the standstill level may be above the current level of the activist fund's ownership (thus allowing it to buy more). See supra note 38 and accompanying text. 


\section{dential information. ${ }^{93}$ Nonetheless, other factors appear to dis- suade the hedge fund from such trading. ${ }^{94}$}

Even if the activist fund does not itself trade in the target's stock, its employees and allies may feel less constrained and might trade through hidden agents. Still, these agreements also do not typically make the activist liable for the trading by their employees, advisors, or other tippees; instead, they often only recite a formula that effectively states that each side knows the law. ${ }^{95}$ In contrast, the directors nominated by activists are probably the group least likely to trade, both because of their visibility and clear fiduciary status and because of Section 16(b) of the Securities Exchange Act, which requires public disclosure through a filing with the SEC of purchases and sales

93 From our review of settlement agreements, the vast majority do not explicitly prohibit the directors or the hedge fund from trading in either options or the common stock of the target firm (although some do restrict trading in any derivatives of the target's stock, including put and call options, and some do restrict short selling). That said, there are several factors which make it difficult for the hedge fund itself to profit from informed trading on open-market stock trades. First, there is generally an effective upper bound on the amount of stock the activist may acquire. Many settlement agreements contain a standstill percentage somewhat above the current level of the activist's ownership, which higher level the activist agrees to not to exceed. Even where a settlement does not specify a standstill percentage, very few activists are willing to cross the $10 \%$ ownership threshold, in part because of the added requirements and penalties imposed by Section 16 of the Securities Exchange Act, which apply to any 10\% holder regardless of whether it has a nominee on the board. In addition, the $10 \%$ level is avoided because it is often "socially acceptable" to put a poison pill in place with a $10 \%$ threshold, as owning more than $10 \%$ is generally viewed as a prelude to a takeover/sale attempt. Also, if the hedge fund increases its position in the target by more than $1 \%$, it is required to amend its Schedule 13-D and promptly disclose this increased holding. See 17 C.F.R. § 240.13d-2(a) (2018). This may attract undesired scrutiny if the activist is trading on nonpublic information. For these reasons, activists are unlikely to directly increase their long positions substantially after signing the standstill, though such trades can obviously still occur within and up to these bounds.

94 See discussion supra at note 93.

95 Frequently, the settlement agreement will provide: "Each of the Investors hereby acknowledges that it is aware that the United States securities laws prohibit any person who has material, nonpublic information with respect to the Company from transacting in the securities of the Company or from communicating such information to any other person under circumstances in which it is reasonably foreseeable that such person is likely to transact in such securities." Dillard's Inc., Information to be Included in Statements Filed Pursuant to Rule 13d1(a) and Amendments Thereto Filed Pursuant to Rule 13d-2(a) (Schedule 13-D) 40 (Apr. 1, 2008). Here, three activist funds and their affiliates state that they recognize what the law requires, but make no guarantees or contractual commitments. At a minimum, a large number of persons are here acquiring material, nonpublic information. We have found this format to be widely used. In our view, these are self-serving provisions that permit the activist investor to express shock and dismay (but incur no liability) if one of its advisors or employees later misbehaves and tips others. 
by directors, and requires the director to surrender any "shortswing" profits to the corporation. 96

More plausible then is trading by tippees of the activist or its employees. If the hedge fund or its employees share material, nonpublic information acquired from access to the target's board with the fellow members of its "wolf pack" of allies, the trading by these allies would be harder to detect and legally more difficult to prosecute. Alternatively, employees of the hedge fund may just enjoy gossiping with professional colleagues, possibly anticipating that their sharing of information will earn them reciprocal favors in the future. This implicit view of Wall Street as a giant "favor bank" seems consistent with the facts of some recent cases, including Newman, where tippees working for one hedge fund have shared nonpublic information with colleagues in other funds. ${ }^{97}$ Finally, under some circumstances, the activist fund's tipping might be perfectly lawful. For example, if the activist fund secures a promise of confidentiality from another investor, a SEC rule permits it to share confidential, nonpublic information with that investor, and the tipper may sometimes have a legitimate corporate justification for such information sharing. ${ }^{98}$ If the activist obtains such a promise, it can later claim that it acted entirely

96 See 18 U.S.C. $\S 78$ p(b) (2018). Section 16(b) requires a director to file Form 4 and Form 5 with the SEC. Form 4 must be filed by "the end of the second business day following the day on which the subject transaction has been executed." See 17 C.F.R. § 240.16a-3(g)(1) (2018). Moreover, upon the acquisition or disposition of $1 \%$ or more of the common, the activist must file an amendment to Schedule 13-D listing all trades in the common that occurred within the past 60 days. And any activist that becomes subject to Section 16-either through $10 \%$ ownership or having an employee on the company board-must file trades on Form 4. Thus, a great deal of an activist's trading activity in the stock will be publicly reported, especially where the fund has an employee on the board. In our dataset, we found that there was little to no suspicious trading reported on either the Schedule 13-D/As or Form $4 \mathrm{~s}$, strengthening the conclusion that activists or their employees are more likely to be tipping rather than trading directly on material nonpublic information.

97 In United States v. Newman, 773 F.3d 438, 448 (2d Cir. 2014), the defendants were fourth and fifth level "remote" tippees and the information moved from employees in one fund to those in another fund, seemingly as a gift. Although Newman is no longer good law in the light of later decisions, the fact pattern illustrates how information flows within the industry and suggests that a norm of reciprocity may encourage information sharing.

98 For example, if the activist fund is trying to organize a proxy contest it may be in the best interests of the fund's investors for its managers to share information about its plans with prospective allies to maximize its leverage over the target firm. The goal of winning a majority vote in a proxy fight requires it to search for allies and explain its reasoning. Regulation Fair Disclosure explicitly recognizes that material nonpublic information may be shared with those who agree to preserve its confidentiality. See 17 C.F.R. § 243.100(b)(2)(ii) (2018) (providing that Regulation FD does not apply to a disclosure to a person "who expressly agrees to 
lawfully and was "shocked" to learn that its tippee acted unlawfully. ${ }^{99}$

Ambiguity surrounds the potential motivations for an activist fund to share confidential information acquired through an employee serving on a target board. Sometimes, it could be, as just noted, an expectation of reciprocity ("I will tip you on my deals, if you tip me on yours"). Sometimes, it may just be casual gossip among traders seeking to impress each other with their knowledge. Still another possibility is that such sharing could be an attempt to hold together a coalition of funds for a longer period. If the lead activist fund can assemble a coalition (or "wolf pack" in the popular parlance) of funds holding somewhere between $15 \%$ and $20 \%$ of the target's voting stock, it would have a considerable advantage over the target's management in any subsequent proxy fight. Facing such odds, target management may prefer to settle than to fight. But why do these allies join this coalition or remain in it? Of course, they could believe in the lead activist's strategy. Another possibility is that they will support the activist in return for access to material, nonpublic information. Here, it is important to understand that the target firm's stock price does not normally increase significantly after the initial price bump following the activist's disclosure of its position with its initial Schedule 13-D filing. One empirical study shows that a measurable price increase after this filing usually occurs only if there is a subsequent "successful outcome" (i.e., a merger or sale transaction). ${ }^{100}$ This implies that the other members of the activist's coalition who buy prior to the initial Schedule 13-D filing may have a reduced incentive to continue to hold the

maintain the disclosed information in confidence"). Of course, those who promise confidentiality may not comply (or they may tip others who do not comply).

99 We have found examples among the settlement agreements we surveyed where, to share confidential information, the activist fund only had to advise its tippee that the information that it provided was confidential. See supra note 56. If such a tippee then traded, the tipper could claim surprise and dismay. To be sure, the tipper's expression of shock at trading by the tippee may not be convincing, but the burden is on the prosecution to show that the tipper expected the tippee to disregard its confidentiality obligation.

100 See Marco Becht et al., Returns to Hedge Fund Activism: An International Study, (Last revised on May 22, 2017), https://papers.ssrn.com/sol3/papers.cfm ?abstract_id=2376271 [https://perma.cc/DP36-FUJF] (finding that stock price of the target only appreciates significantly after the initial jump on the filing of the Schedule 13-D if there is a "successful outcome," such as a merger, takeover bid or major asset sale). Because these transactions are uncertain and often delayed, the activist's allies in the "wolf pack" could decide to bail out and sell their shares if they do not continue to receive encouraging advice or some other benefit (such as nonpublic material information) that motivates them to hold their shares. 
target's stock after that Schedule 13-D filing, particularly if the prospect of such a merger or sale outcome is uncertain or diminishing. Thus, absent some other incentive, these allies might logically sell their individual positions after the initial stock bump (and move on to a new target). But access to material, nonpublic information is an additional and powerful incentive that can motivate these allies to hold onto their positions in the target (and thus enhance the activist's voting power). Also, it is logical to anticipate that there will be marketmoving announcements (positive or negative) in the near future, given the activist's announced plans.

Indeed, if access to nonpublic material information is a likely consequence of joining the activist's coalition, there may be cases in which activist investors join a coalition, even though they doubt the wisdom of the lead activist's proposals. If so, this may imply in turn that a moral-hazard problem could arise, as the supporters of activist engagements may not truly need to evaluate carefully the merits of the activist's proposals if these trading gains are also available.

To be clear, we do not know that investors think or behave in this way. But we do know that someone is trading actively and disproportionately once a hedge fund insider goes on the board. Equally important, we know that the market seems to expect such trading, which is why the bid/ask spread widens on the appointment of a hedge fund employee to the board. To ignore the market's standard reaction is to wear a self-imposed blindfold.

To sum up, even if we do not know whether illegality is occurring, we have evidence that informed trading is common and thus that a dubious subsidy may fuel hedge fund activism on the margin. The gains to those engaged in informed trading are matched by an agency cost to other shareholders: the widening of the bid/ask spread. In fairness, one cannot yet reliably estimate the size of this subsidy. All that is clear is that the desire for access to nonpublic information is strong and could motivate some to join an activist coalition and support the lead activist regardless of their view of the quality of the lead activist's plans. Access to nonpublic information could be the social cement that holds together an otherwise unstable coalition.

\section{B. Preempting the Majority's Preference}

The heyday of hedge fund activism began a decade or so ago when traditional institutional investors (who are typically 
diversified, often indexed, and generally passive) began to support the proposals advanced by activist hedge funds. That support enabled hedge funds typically holding less than $10 \%$ of an issuer's stock to compel management to negotiate with them for fear of losing a hostile proxy fight in which the diversified institutional investors would vote to support the undiversified hedge funds.

But more recently that alliance has come under strain. A fissure has clearly developed between hedge fund activists and an institutional investor community that fears the short-term bias of activism. As noted earlier, the three largest institutional shareholders are Vanguard, BlackRock, and State Street, which collectively hold $18.4 \%$ of the stock in S\&P 500 companies. ${ }^{101}$ Over recent years, "passive investors" have greatly increased their share in the ownership of large U.S. corporations such that the top ten institutional shareholders, most of whom fall into this "passive" category, now hold roughly $32 \%$ of the stock in S\&P 500 companies. ${ }^{102}$ Unlike activist hedge funds, these institutions have regularly expressed disagreement with the goals of activists. In particular, the CEOs of BlackRock and Vanguard sent much-publicized letters in 2015 to their fellow CEOs at large-cap companies urging them not to take the short-term view advocated by activist hedge funds. ${ }^{103}$ Then in 2016, these institutions and others agreed with major corporations on statements of corporate governance principles that sought to shift the focus away from short-term results. ${ }^{104}$

\footnotetext{
101 LAZARD (2018), supra note 4 , at 8.

$102 \mathrm{Id}$.

103 See Laurence D. Fink, Larry Fink's 2016 Corporate Governance Letter to CEOs, BLACKROCK (Feb. 1, 2016), https://www.blackrock.com/corporate/en-no/ literature/press-release/2016-larry-fink-ceo-letter.pdf [https://perma.cc/BY2ZL9PX]; Laurence D. Fink, Larry Fink's Annual Letter to CEOs: A Sense of Purpose, BLACKROCK (Jan. 17, 2018), https://www.blackrock.com/corporate/en-no/investor-relations/larry-fink-ceo-letter [https://perma.cc/2VWZ-PS4E]; F. William McNabb III, An Open Letter to Directors of Public Companies Worldwide, VANGUARD (Aug. 31, 2017), https://about.vanguard.com/investment-stewardship/governance-letter-to-companies.pdf [https://perma.cc/J82B-2E8B]; F. William McNabb III, Letter to the Independent Leaders of the Boards of Directors of the Vanguard Funds' Largest Portfolio Holdings, VANGUARD (Feb. 27, 2015), https:// about.vanguard.com/investment-stewardship/CEO_Letter_03_02_ext.pdf [https://perma.cc/QZU8-GAWZ].

104 The leading example is "Commonsense Corporate Governance Principles," a statement adopted in July 2016 by a coalition of nineteen CEOs (including Warren Buffett and the CEOs of General Motors and J.P. Morgan Chase \& Co.) and the CEOs of several major investment firms (including BlackRock). See Commonsense Corporate Governance Principles, GOVERNANCEPRINCIPLES.ORG, http:// www.governanceprinciples.org; [https://perma.cc/BQ9G-5Y39] (last visited Oct. 29, 2018); see also Yaron Nili, Out of Sight, out of Mind: The Case for Improving
} 
Later in 2016, State Street Global Advisors (SSGA) shifted the focus from substantive goals to procedures, releasing an elaborate statement criticizing the willingness of corporations engaged by activists to enter into quick and private settlements with activists without first seeking the input of long-term shareholders (such as, of course, themselves). ${ }^{105}$ SSGA was clearly on to something here; it saw that risk-averse managers would rather concede two directors to activists than take the risk of a hostile proxy contest and possibly a humiliating defeat. As SSGA pointed out, less than $10 \%$ of board seats conceded in activist campaigns in 2015 and 2016 had resulted from a proxy contest (as opposed to 34\% in 2014); ${ }^{106}$ the other seats were resolved through private negotiations between the company and the activists.

SSGA objected to the process surrounding these agreements even more than to their substance (which they saw as inducing the company to focus on the short-term). Procedurally, SSGA and its clients believed themselves to be disenfranchised by these private settlements. In its 2016 statement, SSGA made several specific proposals as to the duration of such agreements, the requisite holding period for shares held by activists, the pledging of activist shares, and the need for fund-nominated directors to resign in certain circumstances. ${ }^{107}$ Procedurally, SSGA announced they would engage with companies ex post to evaluate these settlements. Unfortunately, this resembles locking the barn door after the horse has

Director Independence Disclosure, 43 J. CORP. L. 35, 37 (2017) (discussing this coalition statement).

105 See Protecting Long-Term Shareholder Interests in Activist Engagements, supra note 5 , at 2 .

106 Id.

107 Specifically, SSGA objected to the following:

Duration. SSGA estimated that the duration of most settlement agreements ran from six to eighteen months, and it suggested that the agreements continue for a longer period (but it did not specify the proposed duration).

Share Holding Periods. SSGA argued that "an activist firm should be required to hold its shares for long periods from the date of the settlement to align them with longer-termed shareholders." Id. at 2. Minimum Ownership Thresholds. SSGA objected to reduction of the activist's stake in the target and asked companies to require directors nominated by activists to tender their resignations if the activists' ownership level fell below a required minimum threshold.

Restrictions on Pledging. SSGA would limit both short sales and pledging of shares by activists, conduct which it said could endanger the company's stock price.

Executive Compensation. SSGA objected to using earnings per share as the primary determinant of CEO compensation.

See Id. 
been stolen. Once a financial engineering strategy has been undertaken or activist directors appointed, these steps are not easily reversed.

Thus, although SSGA's critique won much applause, it did not outline a feasible strategy for the future and managements engaged by activists would predictably continue to take the course of least resistance and settle privately. Accordingly, the next Part will focus on feasible strategies, both to protect the long-term shareholder from disenfranchisement and to reduce the subsidy that informed trading may be providing to fuel activism.

\section{Practical Reforms}

Two basic problems have been identified to this point: (1) Informed trading may represent a hidden subsidy for activism, which could inflate (on the margin) the rate of activism and justify support for activist proposals of dubious merit; and (2) Long-term shareholders (largely diversified pension and mutual funds, but also exchange traded funds) may be disenfranchised if risk-averse managements would rather privately settle with the activist than undertake a risky fight or enter into broader negotiations with all the shareholders. On the assumption that legislation is unlikely (and Congress dysfunctional), this Part will focus on self-help reforms and possible SEC rules on the premise that the least drastic means should be preferred.

\section{Protecting Against Disenfranchisement}

Let's start with a realistic assumption: once an activist appears and "engages" a target company, that company's management cannot be trusted to side with the majority of the shareholders. Management wants to avoid a costly public proxy fight that it could lose and that would likely result in its eventual ouster. Thus, it is prepared to reach a weak, Neville Chamberlain-like compromise in which it will offer two seats on its board for "peace in our time." In reality, much as in Neville Chamberlain's case, management seldom gets the peace it sought because the appointment of activist directors is regularly followed by the departure of the CEO within a year or two. ${ }^{108}$ Still, management can hope, and so they settle.

108 A study by FTI Consulting in 2016 found that CEO turnover when activist nominees gain board seats was $34.1 \%$ and $55.1 \%$ over the one and two-year period, respectively, following the board appointments. The normal CEO turnover rates are $16.6 \%$ and $30.9 \%$ over one and two-year periods, respectively. See 
Corporate managers also have more reason to fear hedge fund activists than diversified investors, even if the latter hold more stock. This is because undiversified hedge funds hold a small portfolio (in terms of number of companies held), but take large positions in each, tend to focus on only one or two campaigns at a time, and have shown in the past that they will undertake the costs of a proxy fight. In contrast, diversified investors typically own smaller stakes in hundreds of stocks, have modest staffs, and are unlikely to take action with respect to an individual stock that represents only a small proportion of their portfolio. They may vote for or against the activist, but they are reluctant to incur costs.

In this light, it is impractical to expect even an SSGA to take a seat on any of the hundreds of boards that have reason to fear an activist attack in the near future. SSGA does not have sufficient qualified staff to cover the entire corporate waterfront and monitor closely all the companies in its portfolio. Indeed, even if a corporation were to ask SSGA to place a representative on its board (in order to signal the corporation's willingness to resist activists), SSGA (or a similar firm) might logically decline because the presence of an SSGA employee on a corporation's board could restrict its ability to sell that stock (for fear of insider trading liability). Passive investors are passive because they logically prefer liquidity to control. ${ }^{109}$

What then can we realistically expect of diversified institutional investors? Here are two possibilities: First, investors, such as SSGA and BlackRock, who fear they are being disenfranchised by private settlements could form (with other similarly-minded institutions) a steering committee and assemble a team of outside directors (who are not their employees) that they could seek to place on corporate boards in the event of an activist attack. This would take some advance preparation, but the effort and expense could be shared among the dozen (or more) institutions participating in such a committee. This committee could contact the corporation at the outset of an activist campaign to suggest either its own nominees or its desire to be involved in the settlement process. Some corpora-

Sonali Basak \& Beth Jinks, Activist Investors Double Chance of CEO Exits, Study Shows, BlOOMBERG (Sep. 21, 2016, 8:00 AM), https://www.bloomberg.com/ news/articles/2016-09-21/activist-investors-double-chance-of-ceo-exits-studyshows [https://perma.cc/D59P-VM2P].

109 One of the authors has made this argument at considerable length elsewhere. See John C. Coffee, Jr., Liquidity Versus Control: The Institutional Investor as Corporate Monitor, 91 Colum. L. REv. 1277 (1991). Hedge Funds, being relatively undiversified, are an exception to this generalization. 
tions would not welcome this development (as it would complicate their negotiations), but others might see it as giving management more negotiating leverage. This committee would have no authority to bind its members and would act only when it had the support of a majority of its members.

Second, diversified investors, working with ISS or a similar body, could adopt a shareholder-approved bylaw that would preclude board action either to expand the board's size or elect persons to vacancies on the board under certain circumstances. For example, such a bylaw might seek to restrict such board action in cases where a requisite percentage of the shareholders objected. Consider then a bylaw that applied only if, after an activist filed a Schedule 13-D or otherwise "engaged" the company, shareholders representing a larger ownership stake than that announced by the activist in its Schedule 13-D were to file a written demand with the corporation within a specified period, asking the board not to settle with the activist by appointing its nominees. In effect, such a bylaw would bar private settlements and require that the matter be settled instead by a shareholder vote at the annual meeting (unless a majority of the objecting shareholders later withdrew their demand). The core idea here is that in the event of an activist engagement the diversified shareholders could seek to block private settlements (without their consent) if they filed a demand supported by a larger percentage of shares than the activists held. The filing of such a demand would effectively assert that the activists did not represent the "silent majority" of the shareholders. This bylaw would provide that it could only be amended by shareholder action, but procedures could be further specified in the bylaw so that these shareholders could withdraw their demand if an acceptable compromise were reached among the activists, the diversified shareholders, and corporate management. In reality, such a shareholder demand would be intended to start a three-way negotiation between the activists, the "silent majority," and management.

Inevitably, there are some legal issues here, but they can be largely solved or outflanked. ${ }^{110}$ In any event, most corporate

110 First and foremost is the possibility that a shareholder-adopted bylaw may be deemed invalid (at least in Delaware) if it fails to contain language or a provision reserving to the corporation's directors their power to fulfill their fiduciary duties and reach a private settlement in a specific case. See CA, Inc. v. AFSCME Emps. Pension Plan, 953 A.2d 227, 240 (Del. 2008) (determining that shareholder approved bylaws may not usurp the board's power to exercise its fiduciary duty). Several answers are possible to this objection. First, language could be inserted giving the board such power, but only after they fully consulted with the share- 
managements would find it difficult simply to rebuff or challenge such a demand. This demand procedure would give the diversified investor community both flexibility and leverage, as they could first meet with management and negotiate for their own candidate or candidates to join the board, turning to the demand procedure only if they were left unsatisfied. A perceptive corporate management might welcome (and even adopt) such a bylaw because it would be a clear signal to activists that they would encounter stiff resistance at such a company. ${ }^{111}$ This signal might deter some activist engagements, and that may be an important virtue of this bylaw.

\section{Restricting Informed Trading}

Information leakage can injure the corporation and its shareholders in at least two ways: First, premature disclosure may disable the corporation from exploiting opportunities or solving business problems, which it could have done if it had more time. The facts of the famous Texas Gulf Sulphur case illustrate this problem, as heavy insider trading forced the company to disclose its extraordinary ore strike before it could buy the mineral rights on the land surrounding its test drill holes. ${ }^{112}$ In other cases, misappropriated information may be seized and exploited by others (including rival firms), again injuring the corporation. Second, even if premature disclosure does not injure the corporation, informed trading in the corpo-

holders filing the demand. Second, if corporate management sensibly realized that such a provision insulated them, they could themselves amend the certificate of incorporation to add the same provision (which would then no longer be subject to such a legal challenge). Or, the board could amend the bylaws themselves (which arguably should be effective). Even if the bylaw could not be fully enforced, it could still have considerable impact on a corporation that did not want to offend its "permanent shareholders." A second problem is that the solicitation of shareholders to sign such a written demand might be deemed a solicitation subject to the proxy rules. However, several exemptions from the proxy rules seem available here. Rule 14a-2(b)(2) exempts solicitations "where the total number of persons solicited is not more than ten.” 17 C.F.R. § 240.14a-2(b)(2) (2018). Less than ten institutional investors could easily hold $7 \%$ or $8 \%$ of the issuer's stock. Also, those asking institutional investors to sign such a demand could claim the exemption afforded by Rule 14a-2(b)(1) because they would not be seeking proxy authority. The bottom line is that the legal problems here can be solved.

111 Of course, one impact of such a bylaw or charter provision might be to cause activists to directly approach the institutional investor community and work out their proposal with them before approaching the company. But this is desirable.

112 SEC v. Texas Gulf Sulphur Co., 401 F.2d 833 (2d Cir. 1968) (en banc). Essentially, this case held that the SEC could sue corporate managers who traded after a major ore discovery but before its disclosure, but the company's disclosure of the strike, which was hastened by its managers' trading, precluded it from fully realizing all the gains from its discovery. 
ration's stock causes its bid/ask spread to widen and this cost falls on all shareholders. Indeed, even those shareholders who do not trade bear it indirectly because it raises the cost of capital to the corporation. Small as this cost may be in individual transactions, the aggregate cost across the market could be large.

One response to the evidence earlier noted that informed trading occurs regularly once activist nominees (and particularly activist employees) are appointed to the board is to say: enforce the law! If this is unlawful, then arguably there should be criminal prosecutions. But that response, while understandable, may be too simple. There are both legal uncertainties and enormous problems of proof in relying on criminal sanctions or SEC civil enforcement. Prosecutorial resources are limited and also subject to periodic reallocation. This Part will briefly survey these problems and then turn to a proposed rule change that would expand the definition of "group" under the Williams Act, in part in order to simplify insider trading enforcement.

1. Legal Uncertainties. Much trading by hedge funds who are planning an engagement with a corporation appears to be lawful. For example, assume that one activist hedge fund (the Mars Fund) tells five other funds that it is planning to file a Schedule 13-D in two weeks with respect to Widget Corp., which document would list its demands, including that Widget's CEO be replaced. All parties to this communication understand that a significant stock market jump will follow the filing of the Schedule 13-D (probably an abnormal return of 7\% or so). But those trading on this information do not violate U.S. law, because they owe no fiduciary duty to Widget Corp. Similarly, if at a later point the Mars Fund approaches other activists to support it in its proxy campaign to add three directors to the Widget board, the same conclusion follows: no fiduciary duty is owed to Widget-hence no liability.

But the issues become more complex once Mars successfully appoints two directors to Widget's board. Now, the directors do owe a fiduciary duty to Widget and any material, nonpublic information that Mars receives from them (directly or indirectly) makes Mars a potential tippee who is barred from trading. Traditionally, from the Supreme Court's decision in Dirks $v$. SEC, ${ }^{113}$ to the Second Circuit's decision in United States $v$. Newman, ${ }^{114}$ it was necessary for the prosecution to 
show that the tipper received some "personal benefit" from (or on behalf of) the tippee. This burden could often be easily satisfied as an evidentiary matter. For example, if Mars pays a salary to its employees and asks them to sit on the Widget board, this should suffice to constitute the requisite "personal benefit." Even if Mars pays nothing to outside experts it may still have caused them to receive a director's salary from Widget and this too may suffice.

But suppose Mars does not trade Widget shares. Instead, another hedge fund, Jupiter Fund, hears indirectly what the Mars employee on the Widget board learned at the last board meeting. Jupiter has paid nothing to the Mars' employee, but it arguably has received a gift of this information from an insider. If so, Jupiter may have liability. But if the information now leaks from Jupiter to other funds who do not know the origins of the material information, this may be beyond the effective reach of the SEC or the criminal justice system.

The prosecutor's burden in proving insider trading has been substantially simplified by a recent Second Circuit decision, United States $v$. Martoma, ${ }^{115}$ which finds that a "gift" of information made by a tipper to any tippee violates the law, even if no "benefit" is given by the tippee to the tipper, so long as the tipper intends to benefit the tippee. Although this decision would still seemingly require that the recipient of the information know that the gift was given in breach of a fiduciary or similar duty by the tipper, it does not require that there be any

115869 F.3d 58 (2d Cir. 2017) amended and superseded by 894 F.3d 64 (2d Cir. 2018). In its first Martoma decision, the panel majority gave the example of a corporate insider who "instead of giving a cash end-of-year gift to his doorman, gives a tip of inside information with instructions to trade on the information." Martoma, 869 F.3d at 70. The court added: "Thus, we hold that an insider or tipper personally benefits from a disclosure of inside information whenever the information was disclosed with the expectation that the recipient would trade on it[.]" Id. (quotation omitted). In the context of one hedge fund (or an employee thereof) tipping another, this test would seem to be easily satisfied unless there was some credible reason to believe that the tippee would not trade. Then, in June 2018, the Martoma panel substituted a revised decision (still split on the same $2-1$ basis), which changed the governing test. United States v. Martoma, 894 F.3d 64 (2d Cir. 2018). Now, the standard for whether an unlawful gift had been made shifts from whether the tipper expected that the tippee would trade on the information to whether the tipper intended to benefit the tippee. See id. at 83. This change may be more semantic than substantive because a jury can easily find that the tipper was "intending to benefit" even a casual friend. Also, the case of a tip from an insider to his condo's doorman at Christmas (which the first Martoma decision said would violate Rule 10b-5) would now likely violate both the personal benefit standard (because the insider escapes the need to make a pecuniary payment to the doorman) and the gift standard. 
"meaningful close relationship" between the tipper and the tippee (as other Circuits have required). ${ }^{116}$

Although the prosecutor's burden has been simplified by Martoma, it remains true that, as the chain of tippees lengthens, enforcement becomes more difficult and, eventually, impossible. At some point, remote tippees do not know the source of the information or any facts suggesting a breach of duty. Also, the director/tipper may have had legitimate reasons for disclosing the information, first to the hedge fund employing the tipper and possibly even to its allies. If so, this employee has neither violated Rule $10 \mathrm{~b}-5$ nor aided and abetted anyone's trading violation-as, for example, in a case where the employee/director was intending only to discuss the next tactical moves with the rest of the hedge fund's management team. In this light, we cannot safely conclude that the increased "leakiness" surrounding companies with hedge fund employees on their boards necessarily implies that unlawful insider trading has occurred. Nevertheless, the widened bid/ask spread is an agency cost (as is the possibility that premature disclosure may cost the company in other ways).

The relevant question thus raised is whether there is a feasible way to reduce this agency cost. In our view, simple means to this end are available, including, as we next discuss, by expanding the concept of "group" under the Williams Act.

2. Redefining "Group". A word of background is initially necessary. A driving force behind hedge fund activism is the ability of a "wolf pack" of like-minded investors to assemble quickly to threaten (or undertake) a proxy campaign. If all the members of the "wolf pack" were deemed to constitute a "group" under Section 13(d)(3) of the Williams Act, the process of "wolf pack" formation would need to slow, some current members would likely refuse to join the group, and other share-

116 Newman had required a "meaningfully close personal relationship" to trigger the gift theory. United States v. Newman, 773 F.3d 438, 452 (2d Cir. 2014). Both Martoma decisions have disagreed, finding that the tippee need not have such a relationship with the tipper. This change will certainly facilitate the prosecution of information exchanges among hedge funds or their employees. All the prosecutor will need to show is that there was an intention to benefit on the part of the tipper (or, under the personal benefit theory, that the tipper expected some reciprocal benefit in return). Other circuits, however, may still require that there be a "meaningfully close personal relationship." See, e.g., United States v. Bray, 853 F.3d 18, 26-27 (1st Cir. 2017) ("good friends”); United States v. Parigian, 824 F.3d 5, 16 (1st Cir. 2016) (friendship and quid pro quo); SEC v. Yun, 327 F.3d 1263, 1280 (11th Cir. 2003) ("a friend and frequent partner in real estate deals"). Even if other Circuits do continue to require some form of "meaningfully close personal relationship," this is not a high standard (and it may have existed between the tipper and the tippee on the facts of Martoma). 
holders could enter the negotiations with the issuer to suggest other board candidates. On the face of the SEC's rules under the Williams Act, courts could find in many cases that an informal association of activist investors was a "group," 117 but recent judicial decisions have defined "group" narrowly, refusing to treat activist investors who were discussing parallel action to constitute a group. ${ }^{118}$ Even a joint slate of directors proposed by the same investors has not sufficed to convince at least one court to deem this association of investors a "group." 119 Curiously, earlier decisions had found a "group" whenever investors "reached an understanding to act in concert." 120 What explains this judicial shift? Possibly, some recent courts have been reluctant to change the balance of advantage in a takeover battle and did not wish to enjoin a lucrative tender offer over an arguably minor disclosure violation.

Today, however, the issue is not whether courts should block a tender offer because of a possible disclosure shortcoming, but whether an activist-led minority of the shares can assemble a block without disclosure and thereby preempt the preferences of the more passive majority. In such a context, courts should be more sensitive to the likelihood that persons acting in concert have not had to disclose their identities, plans, and stock positions at the time they begin to pressure the board. For example, assume that these hedge funds, each owning 3\% of the target's stock, decide to pressure the target to increase its financial leverage and spin off a third of its assets. If their decision to act in concert made them a group, they would be required to file a joint Schedule 13-D, acknowledging

117 Particular attention needs to be given here to Rule 13d-5(b)(1) ("Acquisition of securities"), which provides as follows:

When two or more persons agree to act together for the purpose of acquiring, holding, voting, or disposing of equity securities of an issuer, the group formed thereby shall be deemed to have acquired beneficial ownership, for purposes of Sections 13(d) and 13(g) of the Act, as of the date of such agreement, of all equity securities of that issuer beneficially owned by any such persons.

17 C.F.R. 240.13d-5(b)(1) (2018). This rule recognizes the possibility of a "voting group"-persons who have agreed to act together, for example, to elect one or more directors.

118 See Hallwood Realty Partners v. Gotham Partners, 286 F.3d 613 (2d Cir. 2002).

119 See meVC Draper Fisher Jurvetson Fund I, Inc. v. Millennium Partners, 260 F. Supp. 2d 616, 631-33 (S.D.N.Y. 2003).

120 See, e.g., Wellman v. Dickinson, 682 F.2d 355, 363 (2d Cir. 1982) (finding that concerted action need not be expressly memorialized in writing to support a finding of a "group"); GAF Corp. v. Milstein, 453 F.2d 709, 717 (2d Cir. 1971) (finding that four shareholders who together owned $10.25 \%$ of outstanding shares and agreed to pool their shares constituted a "group"). 
that they were a group and disclosing their plans. But if they can avoid becoming a "group" simply by declaring that they all planned to act independently, then a Schedule 13-D filing would not be required until one of the three crossed the five percent threshold of Section 13(d).

This timing difference is important because earlier notice would give a greater opportunity for other investors (such as SSGA and other diversified institutional investors) to organize and participate in the negotiations with the issuer. In contrast, in the takeover context, earlier notice only gave the target more time to activate its defenses or seek a white knight.

Even under the narrow view of "group" used by more recent judicial decisions, there is far more reason to find that a "group" exists when the activists are planning (or threatening) a proxy contest. Proxy contests, by definition, require collective action. In contrast, those who simply buy a target's stock in the hopes that there will be a future takeover bid are not acting collectively (even if they regularly communicate). Thus, those who discuss the possibility of asking management to appoint their nominees to the board (with the inherent threat in the background that they will start a proxy contest if rebuffed) seem more properly considered a "group" than those investors who simply purchase the stock and hope that there will be a takeover bid. Put simply, because the former need to act collectively to succeed, they are more appropriately deemed a "group."

Nonetheless, the narrow definition of "group" in recent cases poses a problem. The best answer to this problem would be a new SEC rule, defining the term "group" in the context of hedge fund activism. One possible articulation of such an expanded rule would define a "group" to include:

Any association in fact of persons or entities, formal or informal, that is seeking to appoint directors to the corporation's board, whether through private negotiations or a proxy contest, which was formed prior to the public disclosure of the campaign or effort, including any person who has received information or plans, directly or indirectly, with respect to this effort from another group member (or any employee or agent thereof) and who subsequently purchased stock of such corporation prior to such public disclosure. ${ }^{121}$

121 Thus, any person or entity contacted by the lead activist prior to the filing of its Schedule 13-D would be deemed a member of this group, if it purchased any shares in the target after that point. No formal acceptance (nor any formal rejection) would count if there were share purchases by the putative group member after this tip and before public disclosure. 
This "group" would include all shareholders who purchased the issuer's stock after receiving such a private tip from any other group member. This standard accomplishes two things at once: first, it would exclude the public shareholder who only learns from press reports or news media that activists are seeking to advance a slate of board nominees. Such people, even if they strongly support the slate, were not part of the group that organized the campaign. Second, this standard places considerable weight on the private tipping of information by an activist to its allies; this is what fuels the "wolf pack" and thus should define the group. Tips do not occur randomly; they are made to those whose support and loyalty is sought. When the lead activist tells other hedge funds (or other activists) that it is planning to file a Schedule 13-D next week with respect to Widget Corp., this is not idle gossip. Rather, this is an informal invitation to join the "group," and the law should so recognize.

If those who receive such a tip and then purchase the target's stock were deemed to be members of a Section 13(d) group, the consequence of using the fact of a tip from one activist to another as evidence of a group's formation would be that the existence of the "wolf pack" would have to be disclosed at a much earlier stage. Presumably, the Schedule 13-D would have to be amended as each additional member "joined" the "wolf pack." This idea has at least occurred to the SEC. ${ }^{122}$ Some investors would not want to join the "group" (possibly for fear of liability), but this would only mean that they could not buy the target's shares (at least prior to the public disclosure of the "group" on the filing of the Schedule 13-D). Also, any poison pill that the target's board adopts in response to this disclosure would likely restrict all the "group" members, holding them to their current disclosed stake. In short, the "wolf pack" could less easily grow to the size it has reached in some recent cases. Any proxy contest would likely be a closer battle

122 The SEC has recently begun to suggest that collaborative sharing by the hedge funds of information about a campaign aimed at a specific target could "cross the line" and result in the formation of a "group." See Perrie Michael Weiner \& Patrick Hunnius, Activist Investors-Brace Yourselves for 13D Changes, LAw360 (Apr. 17, 2014, 10:03 PM), http://www.law360.com/articles/529294/ activist-investors-brace-yourself-for-13d-changes [https://perma.cc/S3P4KWPK]; Liz Hoffman, Aruna Viswanatha \& David Benoit, SEC Probes Activist Funds over Whether They Secretly Acted in Concert, WALL ST. J. (June 4, 2015, 4:53 PM), https://www.wsj.com/articles/sec-probes-activist-funds-overwhether-they-secretly-acted-in-concert-1433451205 [https://perma.cc/FHL6FXEC]. 
and other shareholders might petition the board to support their nominees instead.

Is there any chance that the SEC would adopt such an expanded definition of "group"? It fits easily within the statutory language and it is consistent with the existing rules, but in recent years the SEC has stood mutely on the sidelines in the battles between companies and the activists engaging them. This neutrality may have been in part the product of the SEC's knowledge that it would take much criticism from either the corporate community or the institutional investor community if it sided with the other. But there is now evidence that activism is associated with informed trading, a traditional focus of SEC enforcement. Also, the debate over activist tactics is no longer simply a two-sided battle between activist funds and target managements, as the institutional investor community is itself divided (with activists on one side and the "permanent" shareholder community-i.e., BlackRock, SSGA and Vanguard-on the other). By ignoring the "wolf pack," the SEC is increasingly playing the ostrich and rendering itself irrelevant.

3. Disclosure About Confidentiality Restrictions. In our data set, the majority of the settlement agreements did not set forth any provision regarding the sharing of the information learned by the hedge fund's nominees at board meetings, while other settlement agreements only referred to a separate confidentiality agreement whose terms were not disclosed. ${ }^{123}$ Yet our data also shows that the market responds much more positively to the announcement of a settlement agreement with an explicit restriction on information sharing. ${ }^{124}$ This suggests that such information is material to investors. ${ }^{125}$ Hence, given the frequency with which such settlement agreements are filed, the SEC could indicate that it wants greater disclosure (whether in the Form $8-\mathrm{K}$ or in a press release) about the handling of confidential information acquired by the new fund-nominated directors.

123 See supra notes 53-56 and accompanying text.

124 See supra Table 9. The five-day CAR was $2.25 \%$ for settlement agreements with a restriction on information sharing versus $0.42 \%$ for those without such a restriction. See supra note 16 and accompanying text.

125 Beginning with TSC Industries, Inc. v. Northway, Inc., 426 U.S. 438 (1976), the Supreme Court has consistently defined "materiality" by finding that: "An omitted fact is material if there is a substantial likelihood that a reasonable shareholder would consider it important in deciding how to vote." Id. at 439. When the omission of any reference to a confidentiality provision seems to move the market across a wide range of cases (as our data shows), that omission is material. 
This need for fuller disclosure stems in part from the fact that slates of directors sponsored by a hedge fund is both a new phenomenon and a rapidly growing one. Also, under Regulation FD, the issuer may not selectively disclose material information to a hedge fund, unless it has obtained a confidentiality agreement. ${ }^{126}$ All these factors support the case for requiring disclosure of the presence or absence of a confidentiality provision and its terms.

\section{Impact and Possible Rebuttals}

The proposals made here will not stop or cripple hedge fund activism. Nor is that their intent. Still, they should reduce tipping and informed trading, and they would authorize the other shareholders to take self-help measures. These are modest goals that reduce the agency costs associated with hedge fund activism. They increase transparency and shareholder rights, but they do not chill activism.

Nonetheless, we anticipate rebuttals from the proponents of activism. They may argue that the losses from widened spreads and informed trading are small in relation to the gains from activism. Two serious problems surround such an argument: First, the gains from activism are in dispute, and the existing empirical studies prove only that there is a positive stock price reaction at the time the activists file their original Schedule 13-D announcing their position and later if there is a "successful outcome." 127 Absent a successful outcome (such as a takeover or acquisition of the target), stock prices tend not to rise further. ${ }^{128}$ Second and more important, this justification that the gains exceed the losses is an unfortunate example of an "end-justifies-the-means" argument, which should be viewed skeptically, particularly when the conduct is unlawful. The evidence collected in this Article strongly implies that informed trading is systematically occurring after the appointment of fund-nominated directors, and in light of the recent case law, this behavior is likely to be unlawful if the tipper is

126 Under Rule 100(b)(2) of Regulation FD, the prohibition against selective disclosure in Rule 100(a) does not apply to a disclosure "[t]o a person who expressly agrees to maintain the disclosed information in confidence." See 17 C.F.R. $\S 243.100(\mathrm{~b})(2)(\mathrm{ii})(2018)$.

127 See discussion at supra note 1; see also Becht et al., supra note 100, at 31 (reporting results from a large international survey and concluding that the "[s]uccess of the activist business model appears to crucially depend on the activist achieving outcomes." In other words, the appointment of activist directors does not alone create value.).

128 See Becht et al., supra note 100, at 28-31 (activist engagements without a successful outcome do not create shareholder value). 
seeking to benefit the tippee. ${ }^{129}$ To suggest that this behavior should be ignored to facilitate activism is to suggest that pervasive criminal conduct is tolerable if it is profitable. The modern history of Wall Street provides ample evidence that once the rules are recurrently bent or ignored, full scale corruption soon follows. ${ }^{130}$

A more modest variant on this initial claim that information sharing leads to greater benefits than costs is the narrower claim that information sharing does not violate the director's duty of confidentiality under Delaware Law. ${ }^{131}$ To a degree, this may be true, and a respected Delaware Vice Chancellor has argued in a well-known law review article that fund-nominated directors may share confidential information with the activist fund that nominated them. ${ }^{132}$ But even this Article, which reads the somewhat ambiguous precedents very permissively, recognizes that the sharing must stop there and the activist fund cannot then share with others. ${ }^{133}$ We would go further and argue that the director may only share confidential information with the activist fund if the director reasonably believes that adequate restrictions are in place at the fund to ensure confidentiality. As our study shows, such formal policies are uncommon. ${ }^{134}$ Moreover, unlike private equity firms (which hold stakes in unlisted companies whose securities cannot be traded), the activist fund lives in an environment where many will be seeking confidential information from it. Absent strong policies and internal controls, the result of allowing directors to share with the fund that employs them may be continued informed trading. In such an environment, a

129 See supra notes 102,110, 111 and accompanying text (discussing United States $v$. Martoma, under which even gifts of information to casual friends or acquaintances can seemingly be prosecuted if there is an intent to benefit the tippee).

130 This is also the theme of "Junk," a play by Ayad Akhtar, a Pulitzer Prizewinning dramatist, which focuses on the M\&A world of the 1980's and seems loosely based on the career of Michael Milken. Terry Teachout, 'Junk' Review: Bankrupting Entertainment, WALL ST. J. (Nov. 2, 2017, 8:30 PM), https:// www.wsj.com/articles/junk-review-bankrupting-entertainment- 1509669000 [https://perma.cc/YEW3-78BJ].

131 Delaware has long recognized that the director owes a duty of confidentiality. See Henshaw v. Am. Cement Corp., 252 A.2d 125, 129 (Del. Ch. 1969).

132 See Laster \& Zeberkiewicz, supra note 43, at 50.

133 Id. at 55 ("The corporation can also require the director's affiliate to enter into a confidentiality agreement that restricts the use or further dissemination of the information.").

134 See supra notes 53-57 and accompanying text (finding that few corporations in our data set appeared to impose meaningful restrictions). This failure may be, of course, in part a product of management's limited leverage with respect to powerful activists and strong risk aversion. 
director cannot assume confidentiality. Sharing of confidential information by the director with the hedge fund that nominated it should be permissible only when the director has first taken steps to assure himself or herself that adequate policies are in place to assure confidentiality.

\section{CONCLUSION}

Informed trading is closely associated with hedge fund activism, but the mechanism underlying information leakage is unclear. It is far too cynical to conclude that everyone does it. Most do not. Our most striking finding is that there is a radical difference in behavior between fund-nominated directors who are business executives and those who are hedge fund employees. Different norms and moralities (or, at least, different opportunities) appear to separate these two populations. Once a hedge fund employee goes on the board, informed trading is the norm, not the exception. We do not argue that all activist funds are alike or that they all engage in such behavior; nor do we assert that activist funds (or their employees) are trading on insider information. It is possible that some tipping is a cynical exchange of a tip for an expected reciprocal favor in the future. But it is also possible that the more common phenomenon is simply casual gossip among professionals in close contact. At a minimum, we are convinced that the informational partitions, if any, between the activist fund and its allies tend to be porous.

In turn, this implies both that an agency cost is imposed on the other shareholders and that activism is receiving a subsidy in the form of pervasive access to material, nonpublic information. We do not claim that this subsidy alone fuels hedge fund activism, but it likely does inflate the number of engagements and may make otherwise economically marginal hedge fund interventions profitable.

What reforms are justified? One might hope that sunlight is the best disinfectant and thus that the mere announcement of our findings would lead activists both toward preferring outside experts to their own employees as proposed directors and into installing stronger controls protecting confidentiality. Nice as it may be to think so, we are not optimistic that reform will follow automatically from the announcement of our findings. In part, this is because the fund's nominated employee is often the fund's founder, and in part, it is because the activist fund may need to reward its allies in order to maintain its coalition and thus its leverage for any approaching proxy fight. 
Because we find the dominant pattern to be that the hedge fund and the target company do not specify any confidentiality restrictions on the information acquired by the fund's director nominees, we think this might be the first area for the SEC to address. Encouraging stronger confidentiality provisions in settlement agreements (and disclosing their absence) might curb the ease with which private information seems to flow.

Our proposed reforms will hardly cripple hedge fund activism, but they could reduce a perverse subsidy. We recognize that activist funds should be able to reap the gains if the stock prices of their target firms rise after their intervention, but not if prices fall or just fluctuate erratically. We anticipate that our reforms will face resistance, but we see no sound justification for tolerating pervasive information leakage.

Finally, our findings supply a road map for regulators. To date, the prosecution of insider trading has proceeded on an ad hoc, case-by-case basis that is dependent upon enforcers fortuitously stumbling upon a violation (often as the result of whistleblowers or plea bargains with third parties who are rewarded for confessing as to other violations). But, using our approach, regulators could identify suspicious patterns of information leakage and then could turn to the options market to learn who was trading. That would substitute rational search for happenstance. 
ONLINE APPENDIX

\section{EMPIRICAL APPENDIX}

In Appendix Figure 1 , the $\mathrm{x}$-axis is the number of days between the director's appointment date and the Form 8-K filing. This normalization by the "time difference" allows for plotting leakage for Form 8-K filings from different points in time on the same figure. We average the leakage by treatment and control group for each "time difference" and apply nonparametric smoothing piecewise to the pre- and post- periods for each group. 
APPENDIX Figure 1. PARALlel TRENDS. This Figure plots pre and post-time trends on the leakage outcome for the treatment and control groups (chosen by propensity score matching). The $\mathrm{x}$ axis is the number of days between the director appointment date and the Form 8-K filing. This normalization by the "time difference" allows for plotting leakage for Form 8-K filings from different points in time on the same figure. We average the leakage by treatment and control group for each "time difference" and apply piecewise nonparametric kernel regression to the pre- and post- periods for each group. The treatment group is plotted with a solid line, while the control group is plotted with a dotted line in the Figure below.

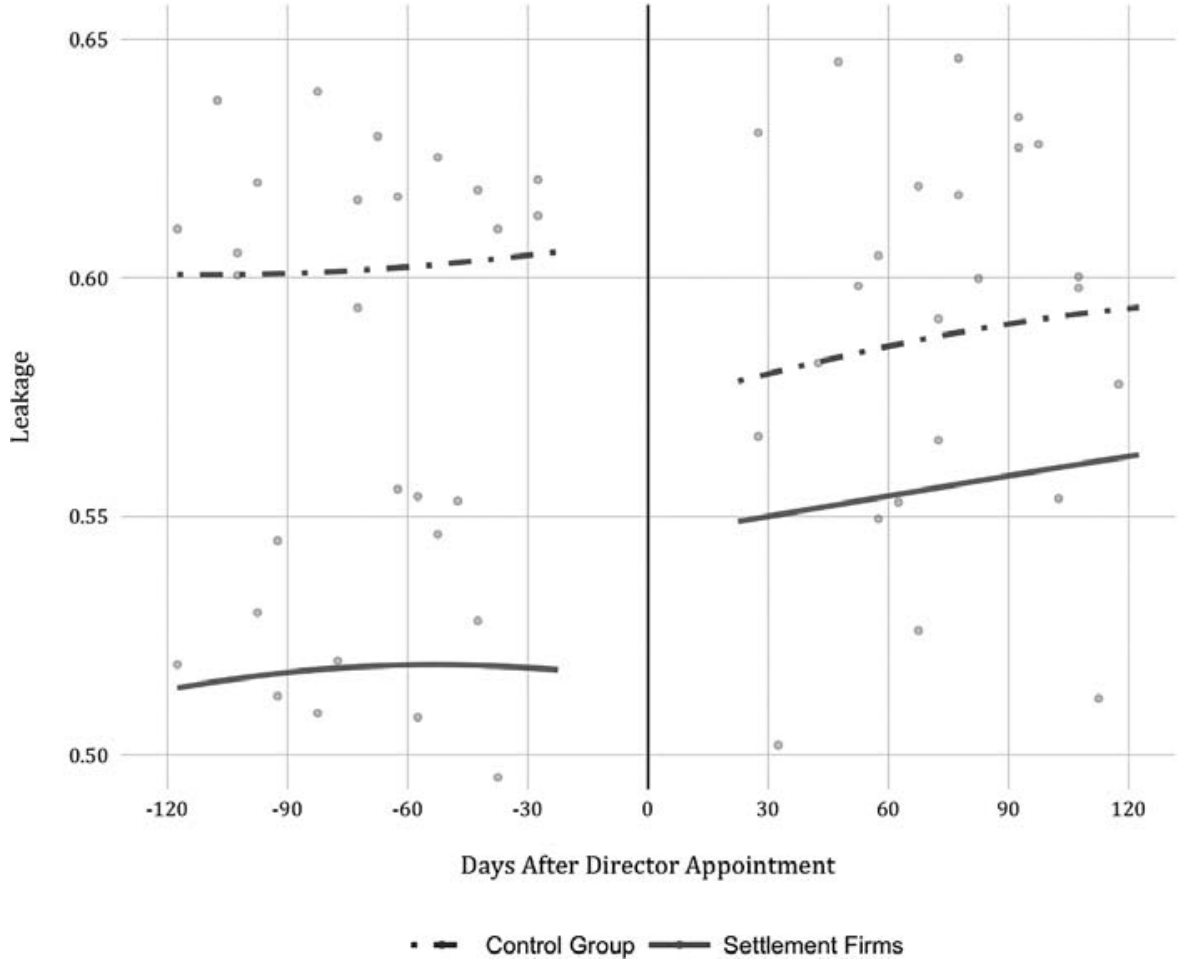

As Appendix Figure 1 shows, trends in leakage over time for our treatment and control groups are parallel prior to the date of the activist director. We observe a shift in those trends only after the appointment of the activist director.

\section{THEORETICAL APPENDIX}

In this Appendix, we explain why, strictly as a theoretical matter, activist investors and target boards might pursue settlement agreements that facilitate access to, and trading upon, material nonpublic information. We show that expected profits from insider trading induce lower-quality activists to engage in 
intervention campaigns than otherwise would, and that the social costs of such informed trading imply a divergence between the private and socially optimal level of activist quality.

We begin with the framework in Burkart and Lee, which considers the payoffs to activism. ${ }^{135}$ In their model, the activist's campaign succeeds with probability $q\left(e_{a}\right) \propto s_{a} \theta_{a} e_{a}$, where $s_{a} \in(0,1)$ is the proportion of shares the activist holds at the conclusion of the campaign, $\theta_{a} \geq 0$ denotes the activist's ability, $e_{a} \geq 0$ denotes her effort. ${ }^{2}$ Firm value after a successful activist campaign is given by $V\left(e_{a}\right)=q\left(e_{a}\right) p_{m}$, i.e., increasing in the probability of success. The activist incurs an effort cost given by:

$$
K\left(e_{a}\right)=\frac{k}{2} e_{a}^{2}+\underline{k}
$$

Although for concision we omit the technical assumptions set out in Burkart and Lee, we briefly restate the sequence of the game they consider. The activist begins with a "toehold" investment in the company, $t_{a} \in(0,1)$ fraction of shares. At $t=-$ 3 , the activist purchases $r_{a}$ shares at the open-market price $p_{a}$. At $t=-2$, the activist chooses whether to engage in an intervention, and if so, what effort level $e_{a}$ to expend. At $t=-1$, upon the successful sale of the firm, the activist receives $s_{a} V\left(e_{a}\right)$, i.e., her share of the value of the firm, which is a function of the effort exerted at $t=-2$.

Like Burkart and Lee, we require that $p_{a} \geq V\left(e_{a}\right)$, i.e., the activist is unable to acquire shares on the open market at a price lower than the ex-post expected value, which is essentially the free-rider problem identified in Grossman and Hart. ${ }^{3}$ We also impose the incentive constraint that $s_{a} V^{\prime}\left(e_{a}\right)=K^{\prime}\left(e_{a}\right)$, i.e., the activist will optimally expend effort until marginal cost is equal to marginal gains.

Next, we augment Burkart and Lee by assuming that the activist also receives a payoff equal to the expected value of engaging in illegal insider trading on the basis of information obtained through access to the corporate boardroom after a

1 Following Burkart and Lee, we adopt the simplifying assumption that the activist seeks to intervene in order to sell the firm to a third-party bidder. See Mike Burkart and Samuel Lee, Activism and Takeovers, https://papers.SSRN. com/sol3/papers.cfm?abstract_id=2585836 [https://perma.cc/ARL8-DNQ8].

2 Unlike Burkart and Lee, we do not explicitly parameterize voting rights and implicitly embrace a rule of one-share, one-vote.

3 Sanford J. Grossman \& Oliver D. Hart, Takeover Bids, the Free Rider Problem and the Theory of the Corporation, 11 BELL J. ECON. 42 (1980). One motivation for this constraint is that, as noted above, federal law mandates disclosure when block holders, including activist shareholders, exceed 5\% ownership. 
settlement agreement. We adopt the notation used in McCrary, ${ }^{4}$ which implies that the activist's problem is given by:

Subject to: $\max s_{a} V\left(e_{a}\right)-K\left(e_{a}\right)-r_{a} p_{a}+E_{t}\left[V\left(B_{t+1}\right)\right]$

$$
\begin{gathered}
p_{a} \geq V\left(e_{a}\right) \\
s_{a} V^{\prime}\left(e_{a}\right)=K^{\prime}\left(e_{a}\right) \\
s_{a}=t_{a}+r_{a}
\end{gathered}
$$

The term $E_{t}\left[V\left(B_{t+1}\right)\right]$ refers to the expected value of the future benefit of insider trading from boardroom access in the dynamic recursive model of McCrary. For present purposes, we consider the simple case where the expected utility from engaging in insider trading is independent of the number of shares acquired. In that case, the solution to the optimization problem is unaffected and the result in Burkart and Lee applies: $r_{a}^{*}=\frac{t_{a}}{2}$. And, as in their model, there exists a unique $\underline{\theta}_{\mathrm{a}}$ such that the activist will engage in the intervention if and only if her $\theta_{a} \geq \theta_{a}$. But we expect $\theta_{a}$ to decrease with $E_{t}\left[V\left(B_{t+1}\right)\right]$ : that is, that as insider-trading profits rise, the activist ability necessary to justify an intervention falls. ${ }^{5}$

Now, let's consider more carefully the term $E_{t}\left[V\left(B_{t+1}\right)\right]$, or the expected value of future gains from insider trading, following McCrary. In that model, the activist is presented each period with a (random) benefit of insider trading, denoted by $B_{t+1}$, which has c.d.f. $F\left(\right.$.). Apprehension occurs with probability $\pi_{t+1}$. For now, we adopt the simplifying assumption that the penalty for insider trading is a single-period punishment $c$, which is deterministic and constant over time. In each period, the activist is presented with the opportunity $B_{t+1}$. If she chooses to commit the crime and is not apprehended, she receives the expected payoff $\delta E_{t}\left[V\left(B_{t+2}\right)\right]+B_{t+1}$, where $\delta$ is the discount factor. If apprehended, she receives the expected payoff $\delta E_{t}\left[V\left(B_{t+2}\right)\right]-c$. If she does not engage in crime, she receives the flow utility $\delta E_{t}\left[V\left(B_{t+2}\right)\right]$. The director's problem is to maximize the recursive value function:

$V\left(B_{t+1}\right)=\max \left\{\delta E_{t}\left[V\left(B_{t+2}\right)\right], \pi_{t}\left(\delta E_{t}\left[V\left(B_{t+2}\right)\right]-c\right)+\left(1-\pi_{t}\right)\left(\delta E_{t}\left[V\left(B_{t+2}\right)\right]+\right.\right.$ $\left.\left.\left.B_{t}+1\right]\right)\right\}$.

4 Justin McCrary, Dynamic Perspectives on Crime, in HANDBOOK ON THE ECONOMICS OF CRIME (Bruce L. Benson \& Paul R. Zimmerman, eds. 2010).

5 The optimal effort is easily calculated (see Burkart and Lee supra note 1) as $e_{a}^{*}=\frac{\theta_{a}}{k} \frac{9}{4} t_{a}^{2} p_{m}$, implying that the activist's expected profit is given by: $t_{a} V\left(\frac{\theta_{a}}{k} \frac{9}{4} t_{a}^{2} p_{m}\right)-K\left(\frac{\theta_{a}}{k} \frac{9}{4} t_{a}^{2} p_{m}\right)+E_{t}\left[V\left(B_{t+1}\right)\right]=\theta_{a}^{2} \frac{27}{32 k} t_{a}^{4} p_{m}^{2}-\underline{k}+E_{t}\left[V\left(B_{t+1}\right)\right]$. For this expression to be positive, a larger $E_{t}\left[V\left(B_{t+1}\right)\right]$ admits a smaller value of $\theta_{a}$. 
The solution is obtained via a "reservation benefit" $b_{t+1}^{*}$ such that for any $B_{t+1}>b_{t+1}^{*}$, the director facilitates insider trading, and otherwise does not. ${ }^{6}$ Straightforward substitution yields $E_{t}\left[V\left(B_{t+1}\right)\right]=\delta E_{t}\left[V\left(B_{t+2}\right)\right]+\left(1-F\left(b_{t+1}^{*}\right)\right)\left(1-\pi_{t+1}\right) E_{t}\left[B_{t+1}-\right.$ $\left.b_{t+1}^{*} \mid B_{t+1}-b_{t+1}^{*}>0\right]$,

and the reservation benefit is given by $b_{t+1}^{*}=\frac{\pi_{t+1}}{1-\pi_{t+1}} c$, which is very similar to the result found in the static Becker model. ${ }^{7}$

We derive the optimal stopping time for the facilitation of illicit trading. Suppose that $B_{t}+1$ ] is uniformly distributed over the interval $[0,1]$ and the probability of detection is given by a standard logistic function of the square root of time:

$$
\pi_{t}=\frac{1}{1+\exp (-\sqrt{t})}
$$

It is plausible to assume that the probability of detection increases with time because it is easier for prosecutors to detect and establish illegal insider trading as the number of trades and abnormal profit increases. It might seem that the probability of detection does not necessarily increase with time, but rather with the number of trades; however, in this simplified model, it is a reasonable approximation, as the agent either "trades or not" and the periods of no-trading do not decrease the probability of detection. With these assumptions, it is straightforward to substitute:

$$
b_{t}^{*}=c \frac{\frac{1}{1+\exp (-\sqrt{t})}}{1-\frac{1}{1+\exp (-\sqrt{t})}}=c \exp (\sqrt{t})
$$

which allows for a straightforward determination of a maximum stopping time $\bar{\tau}$ such that for any $t>\bar{\tau}$, we have that $\operatorname{Pr}\left(B_{\tau}>b_{\tau}^{*}\right)=0$. Suppose, for example, that the punishment $c=$ 0.1 . Then $b_{\tau}^{*}>1$ and $\operatorname{Pr}\left(B_{\tau}>b_{\tau}^{*}\right)=0$ at $\bar{\tau} \approx 5.3$.

However, it is generally better for the director to stop before this time $\bar{\tau}$. Substituting $b_{t}^{*}=c \exp (\sqrt{t})$ in the value function yields, for any period $t \leq \tau$ where $F\left(1-c e^{\sqrt{t}}\right)>0$ (of course, for any period $t>\tau$ where $F\left(1-c e^{\sqrt{t}}\right)=0$, we have that $\left.E_{t}\left[V\left(B_{t+1}\right)\right]=0\right)^{: 8}$

6 See McCrary, supra note 4, for a straightforward derivation of this recursive expected value. We normalize the flow utility to zero, assuming that the activist's profit is given entirely by the benefit $B_{t+1}$.

7 Gary Becker, A Theory of Social Interactions, 82 J. PoL. ECon. 1063 (1974).

8 Recall that $\mathrm{F}\left(\mathrm{B}_{\mathrm{t}+1}\right)=\mathrm{B}_{\mathrm{t}+1}$ in this simple setting. 


$$
\begin{aligned}
& E_{t}\left[V\left(B_{t+1}\right)\right] \\
& =\delta E_{t}\left[V\left(B_{t+2}\right)\right] \\
& +\left(1-c e^{\sqrt{t+1}}\right)\left(1-\frac{1}{1+e^{\sqrt{t+1}}}\right) E_{t}\left[B_{t+1}-c e^{\sqrt{t+1}} \mid B_{t+1}\right. \\
& \left.>c e^{\sqrt{t+1}}\right] \\
& E_{t}\left[V\left(B_{t+1}\right)\right] \\
& =\delta E_{t}\left[V\left(B_{t+2}\right)\right] \\
& +\left(1-c e^{\sqrt{t+1}}\right)\left(1-\frac{1}{1+e^{\sqrt{t+1}}}\right) E_{t}\left[\frac{B_{t+1}-c e^{\sqrt{t+1}}}{1-c e^{\sqrt{t+1}}}\right] \\
& E_{t}\left[V\left(B_{t+1}\right)\right] \\
& \begin{array}{l}
=\delta E_{t}\left[V\left(B_{t+2}\right)\right] \\
+\left(1-c e^{\sqrt{t+1}}\right)\left(1-\frac{1}{1+e^{\sqrt{t+1}}}\right)\left(\frac{1}{1-c e^{\sqrt{t+1}}} E_{t}\left[B_{t+1}\right]-1\right)
\end{array} \\
& E_{t}\left[V\left(B_{t+1}\right)\right]=\delta E_{t}\left[V\left(B_{t+2}\right)\right]+\frac{E_{t}\left[B_{t+1}\right]-1-c e^{\sqrt{t+1}}}{1+e^{\sqrt{t+1}}}
\end{aligned}
$$

Recall that $E_{t}\left[B_{t+1}\right]=\frac{1}{2}$, which leads to:

$$
E_{t}\left[V\left(B_{t+1}\right)\right]=\delta E_{t}\left[V\left(B_{t+2}\right)\right]+\frac{\frac{1}{2}-c e^{\sqrt{t+1}}}{1+e^{\sqrt{t+1}}}
$$

Note that the second term is approximately the derivative of the cumulative value function with respect to time. For $\delta \approx 1$, the optimal stopping time is simply the first-order condition:

$$
\begin{gathered}
\frac{1}{2}-c e^{\sqrt{\tau^{*}}}=0 \\
\tau^{*}=[\ln 2 c]^{2}
\end{gathered}
$$

In general, it will be the case that Consider, again, the example where $c=0.1$, which yields an optimal stopping time of $\tau^{*} \equiv 2.59$. Letting $\delta=0.99$, the cumulative expected value for the upcoming time period is given by:

\begin{tabular}{|c|c|c|}
\hline Time Period & $\boldsymbol{E}_{\boldsymbol{t}}\left[\boldsymbol{V}\left(\boldsymbol{B}_{\boldsymbol{t}+\mathbf{1}}\right)\right]$ & $\boldsymbol{\pi}_{\mathbf{t}}$ \\
\hline $\mathrm{t}=1$ & 0.05952391 & 0.73 \\
\hline $\mathrm{t}=2$ & 0.07584117 & 0.80 \\
\hline $\mathrm{t}=3$ & 0.06689266 & 0.84 \\
\hline $\mathrm{t}=4$ & 0.04168107 & 0.88 \\
\hline $\mathrm{t}=5$ & 0.005558258 & 0.90 \\
\hline
\end{tabular}

ApPendix TaBle 1: Expected Payoff By Stopping Time

As the Appendix Table 1 shows, the activist's expected payoff is indeed maximized by stopping at $t=2$ rather than $t=5$. That is: consistent with the empirical findings described in 
subpart II.A, an activist director may be better off facilitating trading for shorter rather than longer periods of time.

Moreover, $E_{t}\left[V\left(B_{t+1}\right)\right]$ at $t=0$ will be positive only if the stopping time is chosen correctly. Assuming that the director can facilitate profitable insider trading, then, yields a smaller value of $\theta_{a}$ in the Burkart and Lee model-that is, permits lowerquality activists to intervene in public company governance than otherwise would.

It might be tempting to conclude that such conduct, whether or not legally sanctioned, is likely to be social welfareenhancing. Indeed, in the Burkurt and Lee model, social welfare would seem to be strictly enhanced by greater activist participation regardless of activist ability, because firm value, $V\left(e_{a}\right)$ $=s_{a} \theta_{a} e_{a} p_{m}$, is strictly increasing in $\theta_{a}$. On this view, the director's access to insider trading opportunities essentially serve as a subsidy for more value-enhancing activism (or, if one prefers, compensation for the activist's socially valuable work). But it does not necessarily follow that the private optimum is identical to the social optimum because of an externality of the insider trading: wider bid-ask spreads.

Glosten and Putnins argue that informed trading generates welfare losses by leading to wider bid-ask spreads. ${ }^{9}$ One way to formalize this idea is to suppose that the social cost of informed trading can be represented as a function of $\tau$, the number of periods that the activist director facilitates insider trading. In Glosten and Putnins, wider bid-ask spreads impose a social cost by preventing some mutually beneficial transactions from taking place-a cost society incurs in each period in which the insider trades. To see the divergence between the private and social optimum, recall that the expected value of an activist intervention, which we denote as is given as follows, substituting the recursive payoff from insider trading as of time $t=0$ :

$$
\begin{gathered}
E\left[\Pi\left(\theta_{a}, \tau\right)\right]=\theta_{a}^{2} \frac{27}{32 k} t_{a}^{4} p_{m}^{2}-\underline{k}+\sum_{t=0}^{\tau-1} \delta E_{t}\left[V\left(B_{t+2}\right)\right]+\frac{\frac{1}{2}-c e^{\sqrt{t+1}}}{1+e^{\sqrt{t+1}}} \\
E\left[\Pi\left(\theta_{a}, \tau\right)\right]=\theta_{a}^{2} \frac{27}{32 k} t_{a}^{4} p_{m}^{2}-\underline{k}+\sum_{t=0}^{\tau-1} \delta^{t}\left(\frac{\frac{1}{2}-c e^{\sqrt{t+1}}}{1+e^{\sqrt{t+1}}}\right)
\end{gathered}
$$

As noted previously, there generally exists a $\tau^{*}$ that maximizes the last term at a positive value (unless the punishment $c$

9 Lawrence R. Glosten \& Talis J. Putnins, The Welfare Costs of Informed Trade, AM. ECON. Ass'N, https://www.aeaweb.org/conference/2016/retrieve. php? pdfid=808 [https://perma.cc/HF2P-2JZG]. 
for insider trading is so great that an activist will not engage in it at all). And as a result, the minimum quality level $\theta_{a}$ such that for any $\theta_{a}>\underline{\theta_{a}}, E\left[\Pi\left(\theta_{a}, \tau\right)\right] \geq 0$, is lower than in the absence of insider trading opportunities.

Letting $\lambda \tau$ denote the average, per-activist social cost imposed by insider trading through the stopping time $\tau$, the social planner's objective function is given by:

$$
E\left[\Pi_{\text {Social }}\left(\theta_{a}, \tau\right)\right]=\theta_{a}^{2} \frac{27}{32 k} t_{a}^{4} p_{m}^{2}-\underline{k}+\sum_{t=0}^{\tau-1}\left[\delta^{t}\left(\frac{\frac{1}{2}-c e^{\sqrt{t+1}}}{1+e^{\sqrt{t+1}}}\right)\right]-\lambda \tau
$$

And by applying the same approximation as in the prior Subsection, the first-order condition with respect to $\tau$ is given by:

$$
\begin{aligned}
& \frac{1}{2}-c e^{\sqrt{\tau_{\text {social }}^{*}}}-\lambda=0 \\
& \tau_{\text {social }}^{*}=\ln \left[\frac{1}{2 c}-\lambda\right]^{2}
\end{aligned}
$$

It is straightforward to see that $\tau_{\text {Social }}^{*}<\tau^{*}$ for all $c>0$. As the expected value of insider trading increases with $\tau$, there exists a range of values of $\theta_{a}$ for which it is privately, but not socially optimal to engage in activism, i.e., $E\left[\Pi\left(\theta_{a}, \tau\right)\right]>0$ but $E\left[\Pi_{\text {Social }}\left(\theta_{a}, \tau\right)\right]<0$. In Appendix Figure 1 , we plot $E\left[\Pi\left(\theta_{a}, \tau\right)\right]$ and $E\left[\Pi_{\text {Social }}\left(\theta_{a}, \tau\right)\right]$ as a function of $\theta_{a}$ at the optimal stopping times $\tau^{*}$ and $\theta_{\text {Social }}$, respectively, and show the divergence between the socially and privately optimal levels of activist quality. ${ }^{10}$

In sum, we theorize that the payoffs to shareholder activism can include profits related to directors' facilitation of trading on material nonpublic information, and that directors can recursively determine the optimal amount of such activity in light of the probability of detection. Those profits, in turn, decrease the level of activist quality necessary to justify the marginally viable activist intervention. And, while such profits might reflect compensation for socially productive activism in the style of Manne (1965), since the trading that produces those profits can result in widened bid-ask spreads, and since the costs related to widening spreads are not internalized by

10 In Figure 1, for simplicity parameter values are set at $c=0.1, t_{a}=0.1, p_{m}=$ $1, k=3, k=1$, and $\lambda=4$. The example in the Figure is solely for illustrative purposes; the actual divergence, if any, between the social and private optimum depends on the range of these parameters. 
the activist, ${ }^{11}$ there is the potential for a divergence in the socially and privately optimal level of activist quality.

APPEndiX Figure 1. PRIVATEly Optimal vs. Socially OPtimal ACTIVIST QUALITY RANGE. This figure shows the range of the activist quality parameter $\theta_{a}$ and the resulting expected value to activism, after choosing the optimal stopping time $\tau^{*}$ as described in subpart II.B, for the private vs. socially optimal maximization problems. The two expected-value calculations are given by:

$$
\begin{gathered}
E\left[\Pi\left(\theta_{a}, \tau\right)\right]=\theta_{a}^{2} \frac{27}{32 k} t_{a}^{4} p_{m}^{2}-\underline{k}+\sum_{t=0}^{\tau-1} \delta^{t}\left(\frac{\frac{1}{2}-c e^{\sqrt{t+1}}}{1+e^{\sqrt{t+1}}}\right) \\
E\left[\Pi_{\text {Social }}\left(\theta_{a}, \tau\right)\right]=\theta_{a}^{2} \frac{27}{32 k} t_{a}^{4} p_{m}^{2}-\underline{k}+\sum_{t=0}^{\tau-1}\left[\delta^{t}\left(\frac{\frac{1}{2}-c e^{\sqrt{t+1}}}{1+e^{\sqrt{t+1}}}\right)\right]-\lambda \tau
\end{gathered}
$$

Other parameters are set at $c=0.1, t_{a}=0.1, p_{m}=1, k=3, k$ $=1$, and $\lambda=4$. The red shaded region shows the range of activist quality parameter $\theta_{a}$ that yield a positive expected value of activism for the activist but a negative expected value to the social planner.

11 Of course, to the extent that the activist seeks to liquidate their position, the bid-ask spread might be relevant to the activist's private costs (Though we note in this respect that, unlike many shareholders, activists often prefer control to liquidity (compare John C. Coffee, Jr., Liquidity Versus Control: The Institutional Investor as Corporate Monitor, 91 CoLUM. L. REV. 1277 (1991) (finding institutional investors prefer liquidity to control), with Marcel Kahan \& Edward B. Rock, Hedge Funds in Corporate Governance and Corporate Control, 155 U. PA. L. REV. 1021 (2007) (finding that hedge funds' intense activism necessitates less diversification and liquidity than institutional investors)). More importantly for present purposes, however, even these privately internalized costs to the activist are unlikely to be equal to the costs to the investing public imposed by widened bid-ask spreads. Our claim is not that the activist internalizes zero costs of the trading activity, but only that the activist does not internalize all the costs of that activity. 


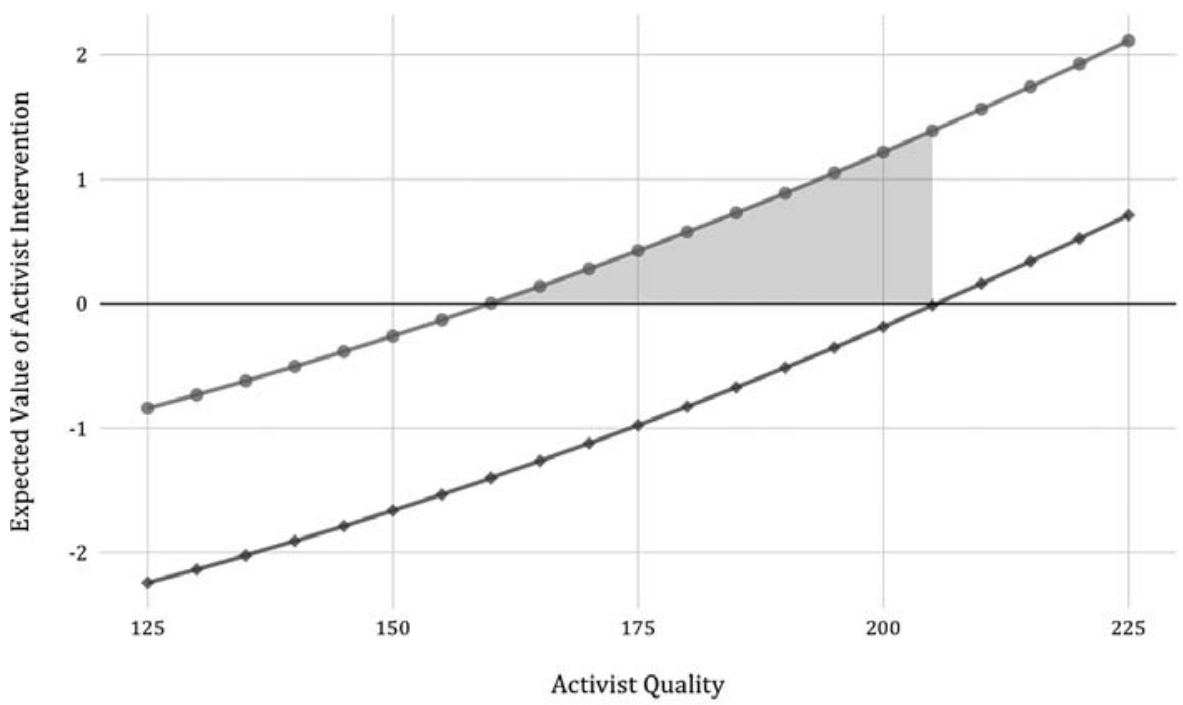

$\longrightarrow$ Privately Optimal $\longrightarrow$ Socially Optimal 